\title{
Improving the Inhibition of TMPRSS2 by Molecular Docking, to Decrease the Process Infection of SARS-CoV- 2
}

\author{
José Luis Vique-Sánchez ${ }^{1, *(i)}$ \\ 1 Medical School, Campus Mexicali, Autonomous University of Baja California, BC, México \\ * Correspondence: jvique@uabc.edu.mx (J.L.V.-S.);
}

Scopus Author ID 57195635710

Received: 23.07.2021; Revised: 15.09.2021; Accepted: 18.09.2021; Published: 16.10.2021

\begin{abstract}
COVID-19 pandemic continues with several works focused on the repositioning of drugs, vaccines, and antibodies against COVID-19, as well as new therapeutic targets on the cellular membrane (ACE2, NRP1, and TMPRSS2) that interacting with SARS-CoV-2 S-protein. This study proposes ten compounds (T1 - T10) selected by molecular docking using a library of nearly 500,000 compounds, these ten compounds have better interaction than Daclatasvir, Ombitasvir, Camostat, Edoxaban, NCGC00386477, Nafamostat, NCGC00386945, Otamixaban, Darexaban, Gabexate, Letaxaban, Argatroban, Sivelestat, NCGC00385043, and Bromhexine, and all of them have an inhibitory effect reported at TMPRSS2. The T1 - T10 compounds were selected by molecular docking in the catalytic site of TMPRSS2, which could hinder/block the interaction with the S-protein and ACE2. Therefore the initial/early stage of COVID-19 could be avoided or decreased by hindering the fusion between SARS-CoV-2 and the cell membrane and this way to develop a new adjuvant treatment against COVID-19.
\end{abstract}

Keywords: TMPRSS2 inhibitors; docking; ACE2; SARS-CoV-2.

(C) 2021 by the authors. This article is an open-access article distributed under the terms and conditions of the Creative Commons Attribution (CC BY) license (https://creativecommons.org/licenses/by/4.0/).

\section{Introduction}

COVID-19 pandemic has caused about 198 million infections and 4 million deaths (July 30, 2021) [1]; COVID-19 causes a wide range of signs and symptoms, mainly respiratory and even deaths [2 - 5]. Different therapeutic targets have been proposed to develop new antivirals, as the polyproteins 3-chymotrypsin like protease (3CLpro) and papain-like protease (PLpro), RNA-Dependent RNA Polymerase (RdRp) [6 - 8], membrane fusion inhibitors heptad repeat 1 and 2 (HR1 and HR2) of Spike protein (S-protein) of SARS-CoV-2 [9 - 15], and receptors or proteins in the cell membrane as angiotensin-converting enzyme 2 (ACE2) [16 21], neuropilin-1 (NRP1) [7, 22, 23], or the trans-membrane protease serine 2 (TMPRSS2) [24], due to these proteins can help to virus to introduce its genetic material and contribute in the infectious process of SARS-CoV-2 [25, 26]. Moreover, several works repurposed treatments with potential effect against COVID-19 [27, 28], and performing docking for drug repositioning and/or with compound libraries to search inhibitors between the S-protein and its receptors [10, 29 - 32].

In this study, TMPRSS2 was the chosen therapeutic target, as it is an important protein for the metabolic process of SARS-CoV-2. It is on the cell surface, expressed mainly in aerodigestive tissue, and the functions of TMPRSS2 are not yet fully described. Moreover, an 
increase in its expression has been identified in prostate cancer tumor cells (metastasis and spread) [33], with changes in its expression levels at different people [34, 35].

The TMPRSS2 has functions for that the SARS-CoV-2 can introduce its genetic material through membrane fusion [26, 33], and the main amino acids have been reported for the interaction with ACE2 [34, 35], as well as it is also proposed that the TMPRSS2 has an interaction with the S-protein (in the cleavage of the S-protein) [36, 37]; the S-protein can be cleaved, and the fusion process with the cell membrane can be favored, which allows the entry of the viral genome [38 - 42], this process has been related in tissues in which there is more expression of TMPRSS2 in the cell membrane (lung tissue) [36, 39].

On the other hand, the development of vaccines/antibodies has been developing [43 46]. However, there are reports of mutations at different proteins in the SARS-CoV-2 that could difficult their effectivity [46, 47], for example, in the S-protein of SARS-CoV-2 (December 2020) that could increase the infectious process and decrease the effect of vaccines [48 - 53].

This study uses reference compounds/drugs that have a therapeutic effect in other diseases, mainly cancer, but that has an inhibitory effect on TMPRSS2 and could generate a therapeutic effect on COVID-19 [38 - 42, 54, 55]. Therefore, it is possible to develop a drug with a therapeutic target in the catalytic site of TMPRSS2 that would have better therapeutic effects against COVID-19. For that, this study proposes to carry out a molecular docking (using almost 500,000 compounds) to select compounds capable of interacting in the catalytic site of TMPRSS2, to decrease the interaction between TMPRSS2 and S-protein, and generating a reduction in the entry of the virus into cells, to propose compounds to develop a new drug against SARS-CoV-2.

\section{Materials and Methods}

\subsection{The homology model of TMPRSS2.}

The homology model of TMPRSS2 was built using the SWISS-MODEL server [56]. The transmembrane trypsin-like serine protease hepsin (TMPRSS1, PDB 1Z8G [57]) was used as the template structure with $24.5 \%$ of identity in the residues of TMPRSS2 (P05981 Heps_Human vs. O15393 TMPS2_Human [58]), and the catalytic sites are highly conserved. The three-dimensional modeled structure was validated by uploading on the RAMPAGE and SAVES 6.0 web servers [59].

\subsection{Preparation of receptor protein and selection of the binding site.}

Atomic coordinates of the model generated of TMPRSS2 was used (the PDB 1Z8G was used as the template structure), the catalytic site in the TMPRSS2 was used as the target for molecular docking using Molecular Operating Environment (MOE), following procedures previously reported $[16,23,60,61]$. Thus, the potential site is between His296, Glu299, Asp435, Ser436, Cys437, Gln438, Ser441, Gly462, Ser463, and Gly464 amino acids, the catalytic site region in TMPRSS2 [38, 40, 55].

\subsection{Compound library used, and drugs/compounds against TMPRSS2 reported for molecular} docking.

The EXPRESS-pick Collection Stock screening library (Chembridge Corp. [62]) was used for molecular docking. This collection of compounds druggable contains 502530 that 
fulfill Lipinski's rules $[63,64]$ and cover a broad area of chemical compound space, as well as the structure of ombitasvir, daclatasvir [42], otamixaban, argatroban, letaxaban, darexaban, edoxaban [39], NCGC00385043, NCGC00386945, NCGC00386477, bromhexine [38, 40, 41, 54], camostat, nafamostat, gabexate and sivelestat [55] to evaluate the interaction with TMPRSS2 [32].

\subsection{Molecular docking.}

For molecular docking, up to 100 conformers were generated from each compound to interact with the potential binding site (compound library and drugs/compounds against TMPRSS2), following procedures previously reported [16, 23]. High-throughput virtual molecular docking was carried out by the software MOE and the analysis of ligand interaction per residue at MOE, AutoDockTools [65], and Protein-Ligand Interaction Profiler [62, 66 68].

\subsection{Selection of the best ten compounds.}

To select the best ten compounds, the results of up to 30 conformers from each compound were used to select them. It was determining the binding free energy ( $\Delta$ Gbinding) of each complex (Ligand-Protein), as previously reported [16, 23] using MOE [69, 70]. With these results, the best averages $\Delta$ Gbinding were determined between TMPRSS2 with each compound, as well as the standard deviation for each one, using the Excel software (Microsoft365), the description of chemical properties by PhysChem - ACD/Labs [71], and the theoretical toxicity (carcinogenicity and mutagenicity) [72 - 74].

\section{Results and Discussion}

\subsection{Selection of compounds by Molecular Docking.}

It was used the Express-pick Collection library from Chembridge Corp. [62] with 502530 compounds, and up to 100 conformers from each compound interacting in the catalytic site in TMPRSS2 (the region between amino acids His296, Glu299, Asp435, Ser436, Cys437, Gln438, Ser441, Gly462, Ser463 and Gly464, Figure 1) for molecular docking, as is reported $[16,23]$, the selection criteria of the best ten compounds was based on the calculation of the average of $\Delta$ Gbinding of each compound, using the values of conformers (27 to 30 conformers), determining an average range from -7.94 to $-8.19 \mathrm{kcal} \mathrm{mol}^{-1}$ for the best ten compounds (Table 1, and details on the supplementary material Table S1). Ten compounds were selected, called here as T1 to T10, and the analysis of the interaction of each compound with TMPRSS2 was carried out with the interaction report (Table 2 and details in Table S1 $\mathrm{S} 11)$. Also, it was determined the average interaction for main drugs/compounds reported to interact with TMPRSS2 (ombitasvir, daclatasvir [42], otamixaban, argatroban, letaxaban, darexaban, edoxaban [39], NCGC00385043, NCGC00386945, NCGC00386477, bromhexine [38, 40, 41, 54], camostat, nafamostat, gabexate and sivelestat [55]), with an average of $\Delta$ Gbinding between $-5.87 \mathrm{kcal} \mathrm{mol}^{-1}$ and $-3.99 \mathrm{kcal} \mathrm{mol}^{-1}$ (interaction details in Table S1 and $\mathrm{S} 12$ - S26). All averages of $\Delta$ Gbinding calculated are related to the number of interactions generated by the conformers analyzed from the molecular docking results (Table 3 ). It is shown that the T1 - T10 compounds interact more frequently with the amino acids Val280, His296, Gly439, and Cys465. 
In addition, the description of the theoretical toxicity (Table S27), ADME characteristics (Table S28), and chemical properties of each compound (T1 - T10, Table S29), are presented in the supplemental material.
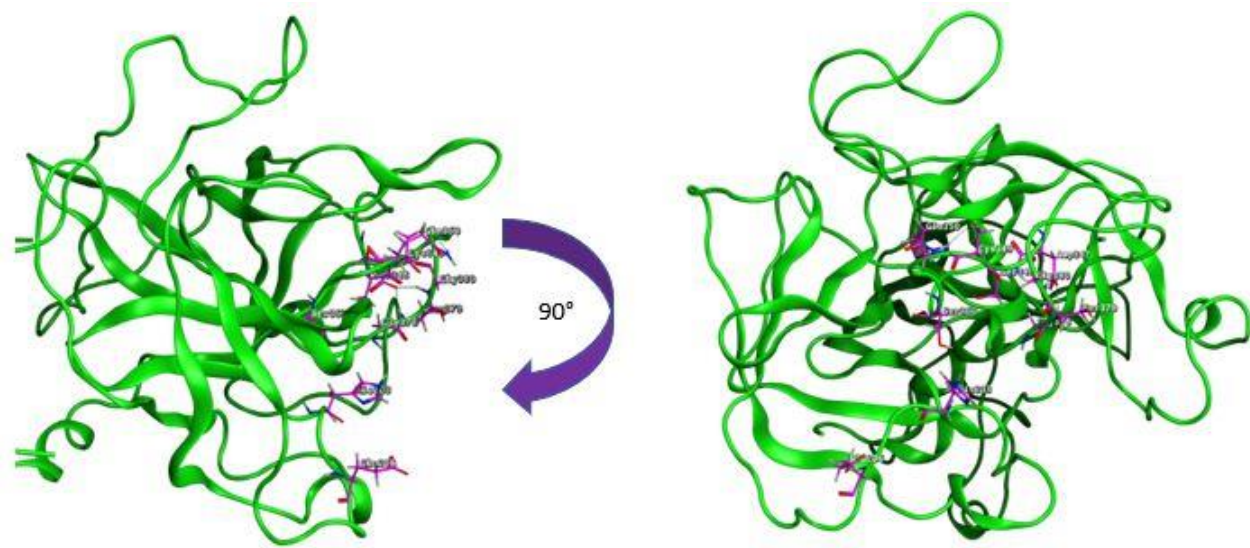

Figure 1. TMPRSS2 (Green) shows amino acids His296, Glu299, Asp435, Ser436, Cys437, Gln438, Ser441, Gly462, Ser463, and Gly464 (Pink) as regions chosen for molecular docking.

Table 1. PubChem CID, ID Chembridge Corp./Name and Structure of the best ten compounds, T1 to T10 and main compound/drugs reported against TMPRSS2.

T1.- 2848720, 5483027.
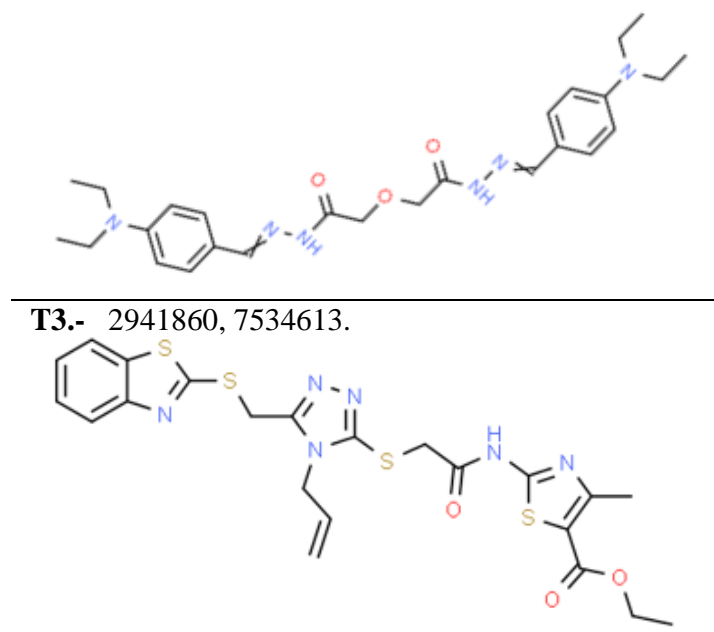

T2.- $5650548,5771448$.<smiles>Cc1ccc(OCc2nnc(SCC(=O)N/N=C/c3coc4ccccc4c3=O)n2-c2ccccc2)cc1C</smiles>

T4.- 2194374,7607092<smiles>C/C=C(\C=C(/C)C(=O)NCc1nnc(OCC(=O)Nc2nc(-c3ccccc3)cs2)n1C)C(=O)O</smiles>

$$
\text { T5.- 1552161, } 5526397 .
$$<smiles>O=C(CN1C(=O)OC(=Cc2ccc(Cl)cc2)C1=O)Nc1ncc(Cc2cccc(C(=O)O)c2)o1</smiles>

T7.- 2193836, 7569492.<smiles></smiles>

T6.- 2851138, 5540972.<smiles>Cc1ccc(S(=O)(=O)[C@@H](C)c2ccc(-c3coc(C4=C(c5ccc(Cl)cc5)CC(c5ccc(C(C)C)cc5)C4)c3)cc2)cc1</smiles>

T8.- 5722665, 5531741.<smiles>COc1ccccc1CC1OC(=O)C(Cc2ccccc2OC)C1=O</smiles> 
https://doi.org/10.33263/BRIAC124.47804846

T9.- $1314888,7507920$.

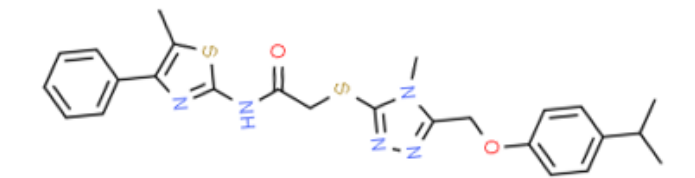

25154714, Daclatasvir.

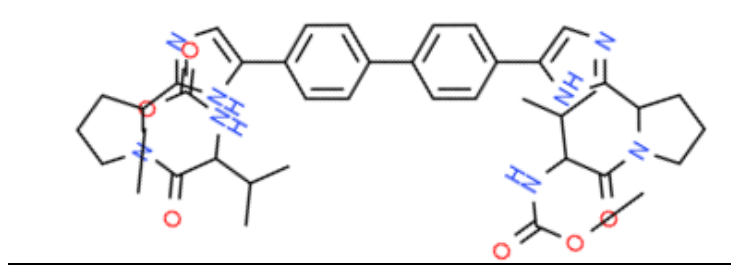

2536, Camostat.

T10.- 2193905, 7573429.

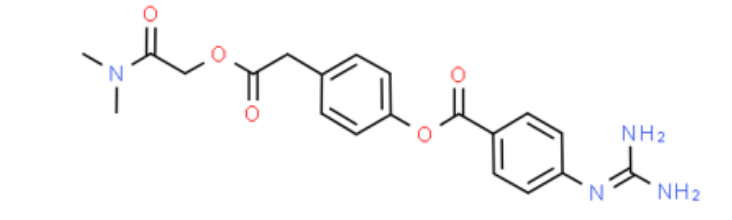

in

54767916, Ombitasvir.
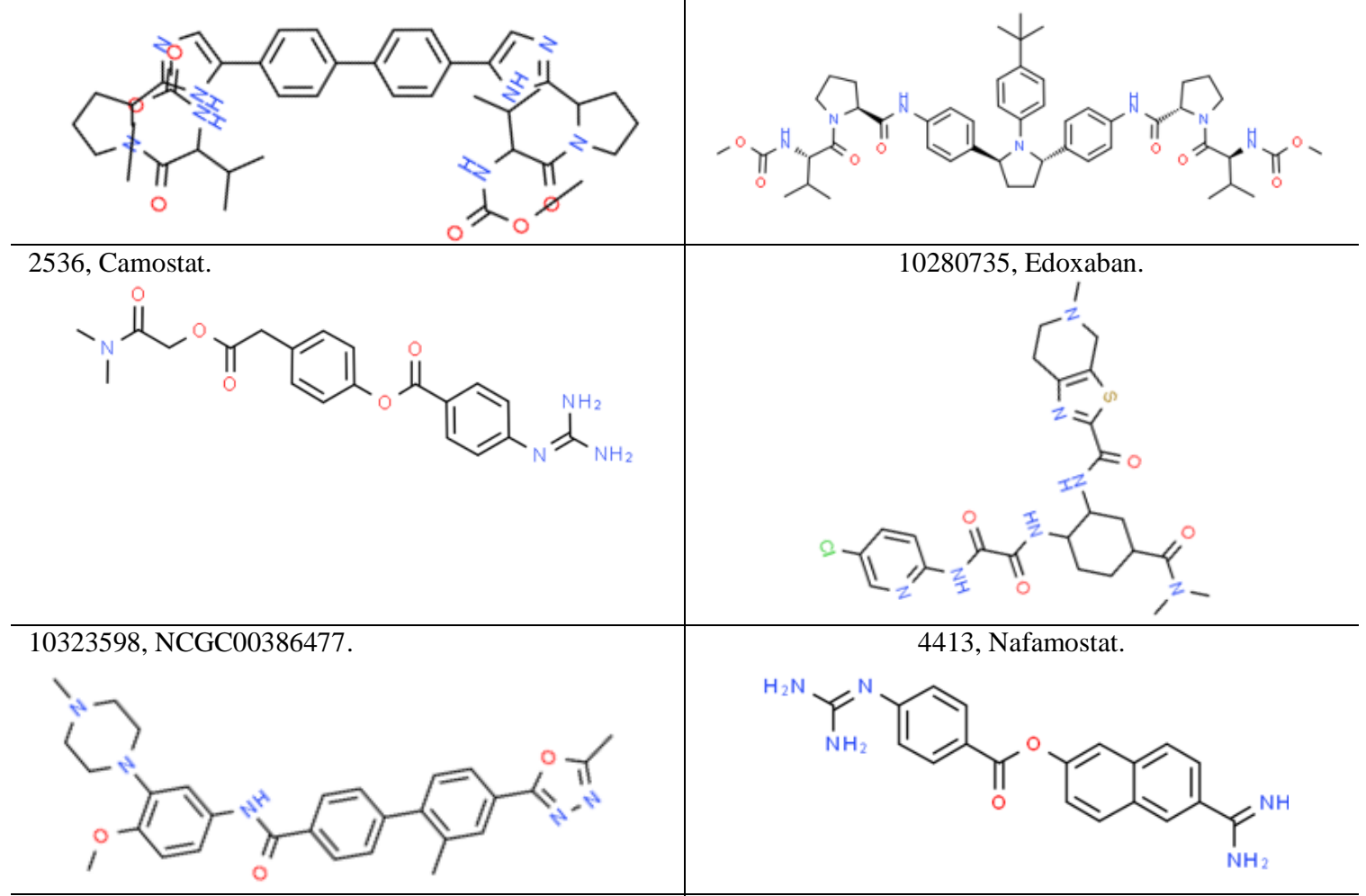<smiles>N=C(N)c1ccc2cc(OC(=O)c3ccc(N=C(N)N)cc3)ccc2c1</smiles>

9846928, NCGC00386945.

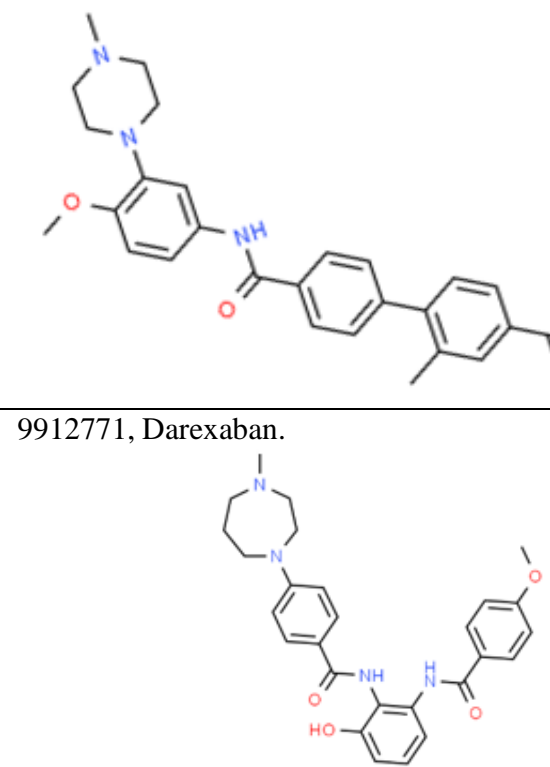

11641515, Letaxaban.

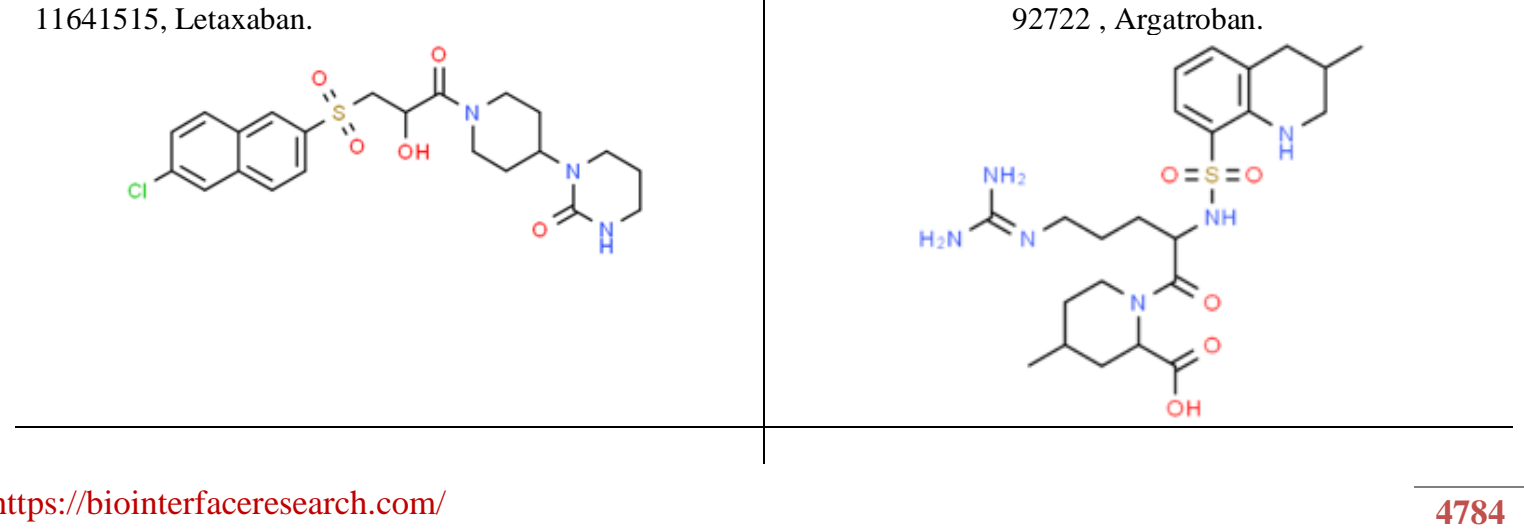<smiles>[Z7]C(=[14CH])c1cccc(CC(C(=O)OC)C(C)C(=O)c2ccc(-c3cc[Z9](O)cc3)cc2)c1</smiles>

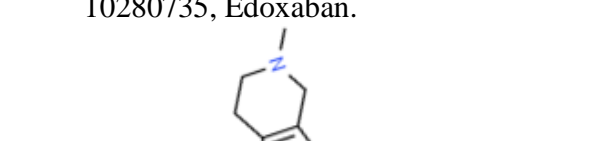

https://biointerfaceresearch.com/<smiles>CCOC(=O)c1ccc(OC(=O)CCCCCNC(=N)N)cc1</smiles> 


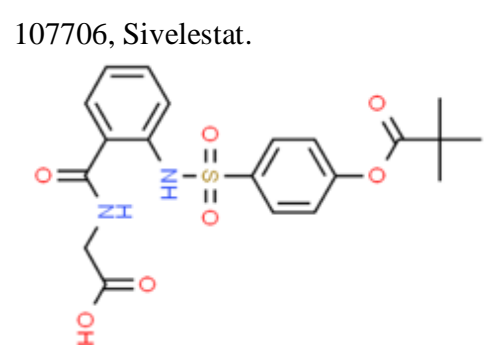

12004581, NCGC00385043.<smiles>CN(Cc1cc(Br)cc(Br)c1N)C1CCCCC1</smiles>

Table 2. PubChem CID, Canonical SMILES, Interaction with residues in TMPRSS2, Number of conformers used, $\Delta$ Gbinding average ( $\mathrm{kcal} \mathrm{mol}^{-1}$ ) with standard deviation (SD), Ames test and strain used (positive or

\begin{tabular}{|c|c|c|c|c|c|}
\hline \multirow[b]{2}{*}{ PubChem CID } & \multirow[b]{2}{*}{ Canonical SMILES } & \multicolumn{2}{|c|}{ negative) and LD50 [72, 74]. } & \multirow[b]{2}{*}{$\begin{array}{l}\text { Average of } \\
\Delta G_{\text {binding }} \text { and SD }\end{array}$} & \multirow[b]{2}{*}{$\begin{array}{l}\text { PreADMET } \\
\text { Ames test and LD50 } \\
\text {-TA100_10RL } \\
\text {-TA100_NA } \\
\text {-TA1535_10R } \\
\text {-TA1535_NA } \\
\text { Predicted LD50 } \\
\text { mg/kg }\end{array}$} \\
\hline & & $\begin{array}{l}\text { Interaction with } \\
\text { residues in TMPRSS2 } \\
\text { (Table } \mathbf{S 2}-\mathrm{S26} \text { ), in } \\
\text { bold it is of greater } \\
\text { interaction. }\end{array}$ & $\begin{array}{l}\text { Number of } \\
\text { conformers }\end{array}$ & & \\
\hline T1.- 2848720 & $\begin{array}{l}\mathrm{CCN}(\mathrm{CC}) \mathrm{C} 1=\mathrm{CC}=\mathrm{C}(\mathrm{C}=\mathrm{C} 1) \mathrm{C} \\
=\mathrm{NNC}(=\mathrm{O}) \mathrm{COCC}(=\mathrm{O}) \mathrm{NN}=\mathrm{C} \\
\mathrm{C} 2=\mathrm{CC}=\mathrm{C}(\mathrm{C}=\mathrm{C} 2) \mathrm{N}(\mathrm{CC}) \mathrm{CC}\end{array}$ & $\begin{array}{l}\text { His296, Asn336, } \\
\text { Ser436, Cys437, } \\
\text { Gly439, Gly462, } \\
\text { Gly464, Cys465 }\end{array}$ & 29 & $-8.19 \pm 0.83$ & $\begin{array}{l}\text { Mutagen } \\
\text {-Positive } \\
\text {-Negative } \\
\text {-Negative } \\
\text {-Negative } \\
5000 \mathrm{mg} / \mathrm{kg}\end{array}$ \\
\hline T2.- 5650548 & $\begin{array}{l}\mathrm{CC} 1=\mathrm{C}(\mathrm{C}=\mathrm{C}(\mathrm{C}=\mathrm{C} 1) \mathrm{OCC} 2= \\
\mathrm{NN}=\mathrm{C}(\mathrm{N} 2 \mathrm{C} 3=\mathrm{CC}=\mathrm{CC}=\mathrm{C} 3) \mathrm{S} \\
\mathrm{CC}(=\mathrm{O}) \mathrm{NN}=\mathrm{CC} 4=\mathrm{COC} 5=\mathrm{CC} \\
=\mathrm{CC}=\mathrm{C} 5 \mathrm{C} 4=\mathrm{O}) \mathrm{C}\end{array}$ & $\begin{array}{l}\text { Val280, His296, } \\
\text { Cys297, Glu299, } \\
\text { Ser436, Gln438, } \\
\text { Gly439 }\end{array}$ & 27 & $-8.10 \pm 0.90$ & $\begin{array}{l}\text { Mutagen } \\
\text {-Positive } \\
\text {-Negative } \\
\text {-Negative } \\
\text {-Negative } \\
1500 \mathrm{mg} / \mathrm{kg}\end{array}$ \\
\hline T3.- 2941860 & $\begin{array}{l}\mathrm{CCOC}(=\mathrm{O}) \mathrm{C} 1=\mathrm{C}(\mathrm{N}=\mathrm{C}(\mathrm{S} 1) \mathrm{N} \\
\mathrm{C}(=\mathrm{O}) \mathrm{CSC} 2=\mathrm{NN}=\mathrm{C}(\mathrm{N} 2 \mathrm{CC}= \\
\mathrm{C}) \mathrm{CSC} 3=\mathrm{NC} 4=\mathrm{CC}=\mathrm{CC}=\mathrm{C} 4 \mathrm{~S} \\
\text { 3) } \mathrm{C}\end{array}$ & $\begin{array}{l}\text { Val280, His296, } \\
\text { Val298, Glu299, } \\
\text { Asn336, Ser436, } \\
\text { Gly439, Gly462, } \\
\text { Cys465 }\end{array}$ & 27 & $-8.01 \pm 0.68$ & $\begin{array}{l}\text { Non mutagen } \\
\text {-Negative } \\
\text {-Negative } \\
\text {-Negative } \\
\text {-Negative } \\
1000 \mathrm{mg} / \mathrm{kg}\end{array}$ \\
\hline T4.- 2194374 & $\begin{array}{l}\mathrm{CN} 1 \mathrm{C}(=\mathrm{NN}=\mathrm{C} 1 \mathrm{SCC}(=\mathrm{O}) \mathrm{NC} \\
2=\mathrm{NC}(=\mathrm{CS} 2) \mathrm{C} 3=\mathrm{CC}=\mathrm{CC}=\mathrm{C} 3 \\
) \mathrm{CNC}(=\mathrm{O}) \mathrm{C} 4=\mathrm{CC}(=\mathrm{CC}=\mathrm{C} 4)[ \\
\mathrm{N}+](=\mathrm{O})[\mathrm{O}-]\end{array}$ & $\begin{array}{l}\text { Val280, His296, } \\
\text { Glu299, Leu302, } \\
\text { Asn336, Ser436, } \\
\text { Cys437, Gly439, } \\
\text { Gly462, Glu464, } \\
\text { Cys465 }\end{array}$ & 30 & $-7.99 \pm 0.59$ & $\begin{array}{l}\text { Mutagen } \\
\text {-Positive } \\
\text {-Positive } \\
\text {-Positive } \\
\text {-Negative } \\
1000 \mathrm{mg} / \mathrm{kg}\end{array}$ \\
\hline T5.- 1552161 & $\begin{array}{l}\mathrm{C} 1=\mathrm{CC}(=\mathrm{CC}(=\mathrm{C} 1)[\mathrm{N}+](=\mathrm{O})[ \\
\mathrm{O}- \\
\text { ]) } \mathrm{CC} 2=\mathrm{CN}=\mathrm{C}(\mathrm{S} 2) \mathrm{NC}(=\mathrm{O}) \mathrm{CN} \\
3 \mathrm{C}(=\mathrm{O}) \mathrm{C}(=\mathrm{CC} 4=\mathrm{CC}=\mathrm{C}(\mathrm{C}=\mathrm{C} \\
\text { 4)Br }) \mathrm{SC} 3=\mathrm{S}\end{array}$ & $\begin{array}{l}\text { Val280, His296, } \\
\text { Cys297, Asn336, } \\
\text { Ser436, Gln438, } \\
\text { Gly439, Trp461, } \\
\text { Gly462, Cys465 }\end{array}$ & 28 & $-7.99 \pm 0.56$ & $\begin{array}{l}\text { Mutagen } \\
\text {-Positive } \\
\text {-Negative } \\
\text {-Positive } \\
\text {-Negative } \\
500 \mathrm{mg} / \mathrm{kg}\end{array}$ \\
\hline T6.- 2851138 & $\begin{array}{l}\mathrm{CC} 1=\mathrm{CC}=\mathrm{C}(\mathrm{C}=\mathrm{C} 1) \mathrm{S}(=\mathrm{O})(=\mathrm{O} \\
) \mathrm{NC} 2=\mathrm{CC}=\mathrm{C}(\mathrm{C}=\mathrm{C} 2) \mathrm{C} 3=\mathrm{CSC} \\
(=\mathrm{N} 3) \mathrm{N} 4 \mathrm{C}(\mathrm{CC}(=\mathrm{N} 4) \mathrm{C} 5=\mathrm{CC}=\end{array}$ & $\begin{array}{l}\text { Val280, His296, } \\
\text { Glu299, Ser436, } \\
\text { Gly439, Gly464 }\end{array}$ & 27 & $-7.99 \pm 0.81$ & $\begin{array}{l}\text { Non mutagen } \\
\text {-Negative }\end{array}$ \\
\hline \multicolumn{5}{|c|}{ https://biointerfaceresearch.com/ } & 4785 \\
\hline
\end{tabular}




\begin{tabular}{|c|c|c|c|c|c|}
\hline PubChem CID & Canonical SMILES & $\begin{array}{l}\text { Interaction with } \\
\text { residues in TMPRSS2 } \\
\text { (Table } \mathrm{S2}-\mathrm{S26} \text { ), in } \\
\text { bold it is of greater } \\
\text { interaction. }\end{array}$ & $\begin{array}{l}\text { Number of } \\
\text { conformers }\end{array}$ & $\begin{array}{l}\text { Average of } \\
\Delta G_{\text {binding }} \text { and SD }\end{array}$ & $\begin{array}{l}\text { PreADMET } \\
\text { Ames test and LD50 } \\
\text {-TA100_10RL } \\
\text {-TA100_NA } \\
\text {-TA1535_10R } \\
\text {-TA1535_NA } \\
\text { Predicted LD50 } \\
\text { mg/kg }\end{array}$ \\
\hline & $\begin{array}{l}\mathrm{C}(\mathrm{C}=\mathrm{C} 5) \mathrm{F}) \mathrm{C} 6=\mathrm{CC}=\mathrm{C}(\mathrm{C}=\mathrm{C} 6) \\
\mathrm{C}(\mathrm{C}) \mathrm{C}\end{array}$ & & & & $\begin{array}{l}\text {-Negative } \\
\text {-Negative } \\
\text {-Negative } \\
1000 \mathrm{mg} / \mathrm{kg} \\
\end{array}$ \\
\hline T7.- 2193836 & $\begin{array}{l}\mathrm{CC} 1=\mathrm{C}(\mathrm{N}=\mathrm{C}(\mathrm{S} 1) \mathrm{NC}(=\mathrm{O}) \mathrm{CS} \\
\mathrm{C} 2=\mathrm{NN}=\mathrm{C}(\mathrm{N} 2 \mathrm{C}) \mathrm{CNC}(=\mathrm{O}) \mathrm{C} 3 \\
=\mathrm{CC}(=\mathrm{CC}=\mathrm{C} 3)[\mathrm{N}+](=\mathrm{O})[\mathrm{O}- \\
]) \mathrm{C} 4=\mathrm{CC}=\mathrm{CC}=\mathrm{C} 4\end{array}$ & $\begin{array}{l}\text { Val280, His296, } \\
\text { Glu299, Asn336, } \\
\text { Lys390, Gln438, } \\
\text { Gly439, Gly462 }\end{array}$ & 28 & $-7.97 \pm 0.80$ & $\begin{array}{l}\text { Mutagen } \\
\text {-Positive } \\
\text {-Positive } \\
\text {-Negative } \\
\text {-Negative } \\
1000 \mathrm{mg} / \mathrm{kg} \\
\end{array}$ \\
\hline T8.- 5722665 & $\begin{array}{l}\mathrm{COC} 1=\mathrm{CC}=\mathrm{CC}=\mathrm{C} 1 \mathrm{C}=\mathrm{C} 2 \mathrm{C}(= \\
\mathrm{O}) \mathrm{N}(\mathrm{C}=\mathrm{S}) \mathrm{S} 2) \mathrm{CCC}(=\mathrm{O}) \mathrm{NCC} \\
\mathrm{NC}(=\mathrm{O}) \mathrm{CCN} 3 \mathrm{C}(=\mathrm{O}) \mathrm{C}(=\mathrm{CC} 4 \\
=\mathrm{CC}=\mathrm{CC}=\mathrm{C} 4 \mathrm{OC}) \mathrm{SC} 3=\mathrm{S}\end{array}$ & $\begin{array}{l}\text { Val280, His296, } \\
\text { Cys297, Glu299, } \\
\text { Leu302, Lys390, } \\
\text { Gly391, Cys437, } \\
\text { Gln438, Gly439, } \\
\text { Trp461, Gly462, } \\
\text { Cys465, Lys467 }\end{array}$ & 30 & $-7.96 \pm 0.76$ & $\begin{array}{l}\text { Mutagen } \\
\text {-Negative } \\
\text {-Negative } \\
\text {-Negative } \\
\text {-Negative } \\
350 \mathrm{mg} / \mathrm{kg} \\
\end{array}$ \\
\hline T9.- 1314888 & $\begin{array}{l}\mathrm{CC} 1=\mathrm{C}(\mathrm{N}=\mathrm{C}(\mathrm{S} 1) \mathrm{NC}(=\mathrm{O}) \mathrm{CS} \\
\mathrm{C} 2=\mathrm{NN}=\mathrm{C}(\mathrm{N} 2 \mathrm{C}) \mathrm{COC} 3=\mathrm{CC}= \\
\mathrm{C}(\mathrm{C}=\mathrm{C} 3) \mathrm{C}(\mathrm{C}) \mathrm{C}) \mathrm{C} 4=\mathrm{CC}=\mathrm{CC} \\
=\mathrm{C} 4\end{array}$ & $\begin{array}{l}\text { Val280, His296, } \\
\text { Cys297, Glu299, } \\
\text { Asn336, Cys437, } \\
\text { Gly439, Gly464, } \\
\text { Cys465 }\end{array}$ & 28 & $-7.95 \pm 0.81$ & $\begin{array}{l}\text { Mutagen } \\
\text {-Negative } \\
\text {-Negative } \\
\text {-Positive } \\
\text {-Negative } \\
1000 \mathrm{mg} / \mathrm{kg} \\
\end{array}$ \\
\hline T10.- 2193905 & $\begin{array}{l}\mathrm{CCN} 1 \mathrm{C}(=\mathrm{NN}=\mathrm{C} 1 \mathrm{SCC}(=\mathrm{O}) \mathrm{N} \\
\mathrm{C} 2=\mathrm{NC}(=\mathrm{C}(\mathrm{S} 2) \mathrm{C}) \mathrm{C} 3=\mathrm{CC}=\mathrm{C} \\
\mathrm{C}=\mathrm{C} 3) \mathrm{CNC}(=\mathrm{O}) \mathrm{C} 4=\mathrm{CC}(=\mathrm{CC} \\
=\mathrm{C} 4)[\mathrm{N}+](=\mathrm{O})[\mathrm{O}-]\end{array}$ & $\begin{array}{l}\text { His279, Val280, } \\
\text { His296, Glu299, } \\
\text { Asn336, Cys437, } \\
\text { Gln438, Gly439 }\end{array}$ & 29 & $-7.94 \pm 0.83$ & $\begin{array}{l}\text { Mutagen } \\
\text {-Positive } \\
\text {-Positive } \\
\text {-Negative } \\
\text {-Negative } \\
1000 \mathrm{mg} / \mathrm{kg} \\
\end{array}$ \\
\hline $\begin{array}{c}\text { Daclatasvir } \\
25154714\end{array}$ & $\begin{array}{l}\mathrm{CC}(\mathrm{C}) \mathrm{C}(\mathrm{C}(=\mathrm{O}) \mathrm{N} 1 \mathrm{CCCC} 1 \mathrm{C} 2 \\
=\mathrm{NC}=\mathrm{C}(\mathrm{N} 2) \mathrm{C} 3=\mathrm{CC}=\mathrm{C}(\mathrm{C}=\mathrm{C} 3 \\
) \mathrm{C} 4=\mathrm{CC}=\mathrm{C}(\mathrm{C}=\mathrm{C} 4) \mathrm{C} 5=\mathrm{CN}=\mathrm{C} \\
(\mathrm{N} 5) \mathrm{C} 6 \mathrm{CCCN} 6 \mathrm{C}(=\mathrm{O}) \mathrm{C}(\mathrm{C}(\mathrm{C}) \\
\mathrm{C}) \mathrm{NC}(=\mathrm{O}) \mathrm{OC}) \mathrm{NC}(=\mathrm{O}) \mathrm{OC}\end{array}$ & $\begin{array}{l}\text { His296, Glu299, } \\
\text { Gly391, Cys437, } \\
\text { Gln438, Gly439, } \\
\text { Cys465, Lys467 }\end{array}$ & 25 & $-5.87 \pm 0.39$ & \\
\hline $\begin{array}{l}\text { Ombitasvir } \\
54767916\end{array}$ & $\begin{array}{l}\mathrm{CC}(\mathrm{C}) \mathrm{C}(\mathrm{C}(=\mathrm{O}) \mathrm{N} 1 \mathrm{CCCC} 1 \mathrm{C}( \\
=\mathrm{O}) \mathrm{NC} 2=\mathrm{CC}=\mathrm{C}(\mathrm{C}=\mathrm{C} 2) \mathrm{C} 3 \mathrm{C} \\
\mathrm{CC}(\mathrm{N} 3 \mathrm{C} 4=\mathrm{CC}=\mathrm{C}(\mathrm{C}=\mathrm{C} 4) \mathrm{C}(\mathrm{C} \\
)(\mathrm{C}) \mathrm{C}) \mathrm{C} 5=\mathrm{CC}=\mathrm{C}(\mathrm{C}=\mathrm{C} 5) \mathrm{NC}( \\
=\mathrm{O}) \mathrm{C} 6 \mathrm{CCCN} 6 \mathrm{C}(=\mathrm{O}) \mathrm{C}(\mathrm{C}(\mathrm{C}) \\
\mathrm{C}) \mathrm{NC}(=\mathrm{O}) \mathrm{OC}) \mathrm{NC}(=\mathrm{O}) \mathrm{OC}\end{array}$ & $\begin{array}{l}\text { His296, Glu299, } \\
\text { Asn336, Gly303, } \\
\text { Gln438, Ser463, } \\
\text { Cys465, Lys467, } \\
\text { Arg470 }\end{array}$ & 30 & $-5.61 \pm 0.62$ & \\
\hline $\begin{array}{l}\text { Camostat } \\
2536\end{array}$ & $\begin{array}{l}\mathrm{CN}(\mathrm{C}) \mathrm{C}(=\mathrm{O}) \mathrm{COC}(=\mathrm{O}) \mathrm{CC} 1= \\
\mathrm{CC}=\mathrm{C}(\mathrm{C}=\mathrm{C} 1) \mathrm{OC}(=\mathrm{O}) \mathrm{C} 2=\mathrm{CC} \\
=\mathrm{C}(\mathrm{C}=\mathrm{C} 2) \mathrm{N}=\mathrm{C}(\mathrm{N}) \mathrm{N}\end{array}$ & $\begin{array}{l}\text { His296, Glu299, } \\
\text { Gly439, Ser447 }\end{array}$ & 24 & $-5.27 \pm 0.54$ & \\
\hline $\begin{array}{l}\text { Edoxaban } \\
10280735\end{array}$ & $\begin{array}{l}\mathrm{CN} 1 \mathrm{CCC} 2=\mathrm{C}(\mathrm{C} 1) \mathrm{SC}(=\mathrm{N} 2) \mathrm{C}( \\
=\mathrm{O}) \mathrm{NC} 3 \mathrm{CC}(\mathrm{CCC} 3 \mathrm{NC}(=\mathrm{O}) \mathrm{C}( \\
=\mathrm{O}) \mathrm{NC} 4=\mathrm{NC}=\mathrm{C}(\mathrm{C}=\mathrm{C} 4) \mathrm{Cl}) \mathrm{C}( \\
=\mathrm{O}) \mathrm{N}(\mathrm{C}) \mathrm{C}\end{array}$ & $\begin{array}{l}\text { Val280, His296, } \\
\text { Glu299, Ser436, } \\
\text { Gly439, Trp461, } \\
\text { Gly462, Cys465 }\end{array}$ & 26 & $-5.24 \pm 0.64$ & \\
\hline $\begin{array}{c}\text { NCGC0038647 } \\
710323598\end{array}$ & $\begin{array}{l}\mathrm{CC} 1=\mathrm{C}(\mathrm{C}=\mathrm{CC}(=\mathrm{C} 1) \mathrm{C} 2=\mathrm{NN}= \\
\mathrm{C}(\mathrm{O} 2) \mathrm{C}) \mathrm{C} 3=\mathrm{CC}=\mathrm{C}(\mathrm{C}=\mathrm{C} 3) \mathrm{C}( \\
=\mathrm{O}) \mathrm{NC} 4=\mathrm{CC}(=\mathrm{C}(\mathrm{C}=\mathrm{C} 4) \mathrm{OC}) \\
\mathrm{N} 5 \mathrm{CCN}(\mathrm{CC} 5) \mathrm{C}\end{array}$ & $\begin{array}{l}\text { Val280, His } 296, \\
\text { Glu299, Gly462, } \\
\text { Ser463, Cys465, } \\
\text { Lys467 }\end{array}$ & 25 & $-5.21 \pm 0.52$ & \\
\hline $\begin{array}{l}\text { Nafamostat } \\
\quad 4413\end{array}$ & $\begin{array}{l}\mathrm{C} 1=\mathrm{CC}(=\mathrm{CC}=\mathrm{C} 1 \mathrm{C}(=\mathrm{O}) \mathrm{OC} 2= \\
\mathrm{CC} 3=\mathrm{C}(\mathrm{C}=\mathrm{C} 2) \mathrm{C}=\mathrm{C}(\mathrm{C}=\mathrm{C} 3) \mathrm{C}( \\
=\mathrm{N}) \mathrm{N}) \mathrm{N}=\mathrm{C}(\mathrm{N}) \mathrm{N}\end{array}$ & $\begin{array}{l}\text { Val280, His } 296, \\
\text { Glu299, Ser436, } \\
\text { Cys437, Gly439, } \\
\text { Cys } 465\end{array}$ & 23 & $-5.09 \pm 0.45$ & \\
\hline $\begin{array}{l}\text { NCGC0038694 } \\
59846928\end{array}$ & $\begin{array}{l}\mathrm{CC} 1=\mathrm{C}(\mathrm{C}=\mathrm{CC}(=\mathrm{C} 1) \mathrm{C}(=\mathrm{N}) \mathrm{N}) \\
\mathrm{C} 2=\mathrm{CC}=\mathrm{C}(\mathrm{C}=\mathrm{C} 2) \mathrm{C}(=\mathrm{O}) \mathrm{NC} 3\end{array}$ & $\begin{array}{l}\text { His296, Glu299, } \\
\text { Ser436, Cys437, }\end{array}$ & 26 & $-5.03 \pm 0.50$ & \\
\hline
\end{tabular}




\begin{tabular}{|c|c|c|c|c|c|}
\hline PubChem CID & Canonical SMILES & $\begin{array}{l}\text { Interaction with } \\
\text { residues in TMPRSS2 } \\
\text { (Table S2 - S26), in } \\
\text { bold it is of greater } \\
\text { interaction. }\end{array}$ & $\begin{array}{l}\text { Number of } \\
\text { conformers }\end{array}$ & $\begin{array}{l}\text { Average of } \\
\Delta G_{\text {binding }} \text { and SD }\end{array}$ & $\begin{array}{l}\text { PreADMET } \\
\text { Ames test and LD50 } \\
\text {-TA100_10RL } \\
\text {-TA100_NA } \\
\text {-TA1535_10R } \\
\text {-TA1535_NA } \\
\text { Predicted LD50 } \\
\text { mg/kg }\end{array}$ \\
\hline & $\begin{array}{l}=\mathrm{CC}(=\mathrm{C}(\mathrm{C}=\mathrm{C} 3) \mathrm{OC}) \mathrm{N} 4 \mathrm{CCN}( \\
\mathrm{CC} 4) \mathrm{C}\end{array}$ & $\begin{array}{l}\text { Gly462, Ser } 463, \\
\text { Cys465 }\end{array}$ & & & \\
\hline $\begin{array}{l}\text { Otamixaban } \\
5496659\end{array}$ & $\begin{array}{l}\mathrm{CC}(\mathrm{C}(\mathrm{CC} 1=\mathrm{CC}(=\mathrm{CC}=\mathrm{C} 1) \mathrm{C}( \\
=\mathrm{N}) \mathrm{N}) \mathrm{C}(=\mathrm{O}) \mathrm{OC}) \mathrm{NC}(=\mathrm{O}) \mathrm{C} 2= \\
\mathrm{CC}=\mathrm{C}(\mathrm{C}=\mathrm{C} 2) \mathrm{C} 3=\mathrm{CC}=[\mathrm{N}+]( \\
\mathrm{C}=\mathrm{C} 3)[\mathrm{O}-]\end{array}$ & $\begin{array}{l}\text { Val280, His296, } \\
\text { Val298, Glu299, } \\
\text { Ser436, Cys437, } \\
\text { Gln438, Gly439, } \\
\text { Trp461, Gly462, } \\
\text { Cys465 }\end{array}$ & 26 & $-5.01 \pm 0.49$ & \\
\hline $\begin{array}{c}\text { Darexaban } \\
9912771\end{array}$ & $\begin{array}{l}\mathrm{CN} 1 \mathrm{CCCN}(\mathrm{CC} 1) \mathrm{C} 2=\mathrm{CC}=\mathrm{C}( \\
\mathrm{C}=\mathrm{C} 2) \mathrm{C}(=\mathrm{O}) \mathrm{NC} 3=\mathrm{C}(\mathrm{C}=\mathrm{CC}= \\
\mathrm{C} 3 \mathrm{O}) \mathrm{NC}(=\mathrm{O}) \mathrm{C} 4=\mathrm{CC}=\mathrm{C}(\mathrm{C}=\mathrm{C} \\
\text { 4)OC }\end{array}$ & $\begin{array}{l}\text { Val280, His296, } \\
\text { Glu299, Cys437, } \\
\text { Gly439 }\end{array}$ & 26 & $-4.98 \pm 0.46$ & \\
\hline $\begin{array}{c}\text { Gabexate } \\
3447\end{array}$ & $\begin{array}{l}\mathrm{CCOC}(=\mathrm{O}) \mathrm{C} 1=\mathrm{CC}=\mathrm{C}(\mathrm{C}=\mathrm{C} 1) \\
\mathrm{OC}(=\mathrm{O}) \mathrm{CCCCN}=\mathrm{C}(\mathrm{N}) \mathrm{N}\end{array}$ & $\begin{array}{l}\text { Val280, His296, } \\
\text { Glu299, Asn336, } \\
\text { Ser436, Gly439 }\end{array}$ & 29 & $-4.94 \pm 0.30$ & \\
\hline $\begin{array}{l}\text { Letaxaban } \\
11641515\end{array}$ & $\begin{array}{l}\mathrm{C} 1 \mathrm{CNC}(=\mathrm{O}) \mathrm{N}(\mathrm{C} 1) \mathrm{C} 2 \mathrm{CCN}(\mathrm{C} \\
\mathrm{C} 2) \mathrm{C}(=\mathrm{O}) \mathrm{C}(\mathrm{CS}(=\mathrm{O})(=\mathrm{O}) \mathrm{C} 3= \\
\mathrm{CC} 4=\mathrm{C}(\mathrm{C}=\mathrm{C} 3) \mathrm{C}=\mathrm{C}(\mathrm{C}=\mathrm{C} 4) \mathrm{Cl} \\
\mathrm{O}\end{array}$ & $\begin{array}{l}\text { Val280, His296, } \\
\text { Glu299, Asn336, } \\
\text { Ser436, Gln438, } \\
\text { Gly439 }\end{array}$ & 26 & $-4.84 \pm 0.50$ & \\
\hline $\begin{array}{l}\text { Argatroban } \\
92722\end{array}$ & $\begin{array}{l}\mathrm{CC} 1 \mathrm{CCN}(\mathrm{C}(\mathrm{C} 1) \mathrm{C}(=\mathrm{O}) \mathrm{O}) \mathrm{C}(= \\
\mathrm{O}) \mathrm{C}(\mathrm{CCCN}=\mathrm{C}(\mathrm{N}) \mathrm{N}) \mathrm{NS}(=\mathrm{O})( \\
=\mathrm{O}) \mathrm{C} 2=\mathrm{CC}=\mathrm{CC} 3=\mathrm{C} 2 \mathrm{NCC}(\mathrm{C} \\
\text { 3)C }\end{array}$ & $\begin{array}{l}\text { His279, Val280, } \\
\text { His296, Glu299, } \\
\text { Ser436, Gln438, } \\
\text { Gly439 }\end{array}$ & 29 & $-4.75 \pm 0.46$ & \\
\hline $\begin{array}{l}\text { Sivelestat } \\
107706\end{array}$ & $\begin{array}{l}\mathrm{CC}(\mathrm{C})(\mathrm{C}) \mathrm{C}(=\mathrm{O}) \mathrm{OC} 1=\mathrm{CC}=\mathrm{C}( \\
\mathrm{C}=\mathrm{C} 1) \mathrm{S}(=\mathrm{O})(=\mathrm{O}) \mathrm{NC} 2=\mathrm{CC}= \\
\mathrm{CC}=\mathrm{C} 2 \mathrm{C}(=\mathrm{O}) \mathrm{NCC}(=\mathrm{O}) \mathrm{O}\end{array}$ & $\begin{array}{l}\text { His296, Lys390, } \\
\text { Gly391, Cys437, } \\
\text { Gln438, Gly439, } \\
\text { Cys465, Lys467 }\end{array}$ & 26 & $-4.59 \pm 0.46$ & \\
\hline $\begin{array}{l}\text { NCGC0038504 } \\
312004581\end{array}$ & $\begin{array}{l}\mathrm{COC}(=\mathrm{O}) \mathrm{C} 1=\mathrm{COC}(\mathrm{C} 2 \mathrm{C} 1 \mathrm{CC} \\
=\mathrm{C} 2 \mathrm{CO}) \mathrm{OC} 3 \mathrm{C}(\mathrm{C}(\mathrm{C}(\mathrm{C}(\mathrm{O} 3) \mathrm{C} \\
\mathrm{O}) \mathrm{O}) \mathrm{O}) \mathrm{O}\end{array}$ & $\begin{array}{l}\text { Val280, His296, } \\
\text { Ser436, Cys437, } \\
\text { Gly439, Gly462 }\end{array}$ & 30 & $-4.21 \pm 0.34$ & \\
\hline $\begin{array}{l}\text { Bromhexine } \\
2442\end{array}$ & $\begin{array}{l}\mathrm{CN}(\mathrm{CC} 1=\mathrm{C}(\mathrm{C}(=\mathrm{CC}(=\mathrm{C} 1) \mathrm{Br}) \\
\mathrm{Br}) \mathrm{N}) \mathrm{C} 2 \mathrm{CCCCC} 2\end{array}$ & $\begin{array}{l}\text { Val280, Ser436, } \\
\text { Cys437, Gly439 }\end{array}$ & 21 & $-3.99 \pm 0.30$ & \\
\hline
\end{tabular}

Table 3. Number of interactions of each compound/drug in the residues of TMPRSS2 (Table S2 - S26), to hinder/block the Ser441 in TMPRSS2.

\begin{tabular}{l|l|l|l|l} 
Compound/Drug & Val280 & His296 & Gly439 & Cys465 \\
\hline T1 & 1 & 17 & 5 & 5 \\
\hline T2 & 5 & 21 & 7 & 0 \\
\hline T3 & 9 & 12 & 6 & 2 \\
\hline T4 & 13 & 17 & 6 & 2 \\
\hline T5 & 9 & 21 & 8 & 2 \\
\hline T6 & 3 & 14 & 2 & 0 \\
\hline T7 & 4 & 15 & 9 & 0 \\
\hline T8 & 3 & 27 & 12 & 6 \\
\hline T9 & 7 & 15 & 10 & 2 \\
\hline T10 & 6 & 18 & 7 & 0 \\
\hline Daclatasvir & 0 & 5 & 2 & 10 \\
\hline Ombitasvir & 0 & 10 & 1 & 2 \\
\hline Camostat & 0 & 14 & 2 & 0 \\
\hline Edoxaban & 1 & 18 & 6 & 2 \\
\hline NCGC00386477 & 2 & 5 & 0 & 2 \\
\hline Nafamostat & 3 & 7 & 6 & 3 \\
\hline NCGC00386945 & 0 & 3 & 1 & 2 \\
\hline Otamixaban & 3 & 13 & 3 & 2 \\
\hline Darexaban & 3 & 7 & 4 & 1 \\
\hline Gabexate & 3 & 6 & 5 & 1 \\
\hline Letaxaban & 9 & 11 & 3 & 0 \\
\hline Argatroban & 2 & 67 & 8 & 0 \\
\hline Sivelestat & 0 & 49 & 8 & 7
\end{tabular}




\begin{tabular}{l|l|l|l|l} 
Compound/Drug & Val280 & His296 & Gly439 & Cys465 \\
\hline NCGC00385043 & 1 & 9 & 7 & 0 \\
\hline Bromhexine & 3 & 2 & 4 & 0
\end{tabular}

\subsection{Interaction of $T 1-T 10$ compounds and other compounds/drugs previously reported} against TMPRSS2.

To describe the interaction of each compound/drug in the potential site of TMPRSS2, it was analyzed up to 30 conformers from each compound interacting in the catalytic site (region between amino acids His296, Glu299, Asp435, Ser436, Cys437, Gln438, Ser441, Gly462, Ser463 and Gly464) (Figure 1). From molecular docking results, the main amino acids in TMPRSS2 are Val280, His296, Cys297, Glu299, Leu302, Lys390, Gly391, Cys437, Gln438, Gly439, Trp461, Gly462, Cys465, and Lys467 that are interacting with the T1 - T10 compounds (Table S2 - S26), and these ten compounds have a better interaction in the catalytic site, in particular, greater interaction with Val280, His296, Glu299, Gly439 and Cys465 (mainly hydrogen bonding interactions). Therefore, the probably inhibitory effect in this protease is due to the blocking of the Ser441, which is essential for the catalytic activity [38, 40, 55] (Figure 2). The molecular docking results for daclatasvir, ombitasvir, camostat, edoxaban, NCGC00386477, nafamostat, NCGC00386945, otamixaban, darexaban, gabexate, letaxaban, argatroban, sivelestat, NCGC00385043, and bromhexine showed less interaction in the catalytic site (Table 3), which could be related to a lesser effect to reduce the function of this protease. The details of the interaction between TMPRSS2 with conformers from each compound/drug are shown in the supplementary material (Figure S1 - S25).
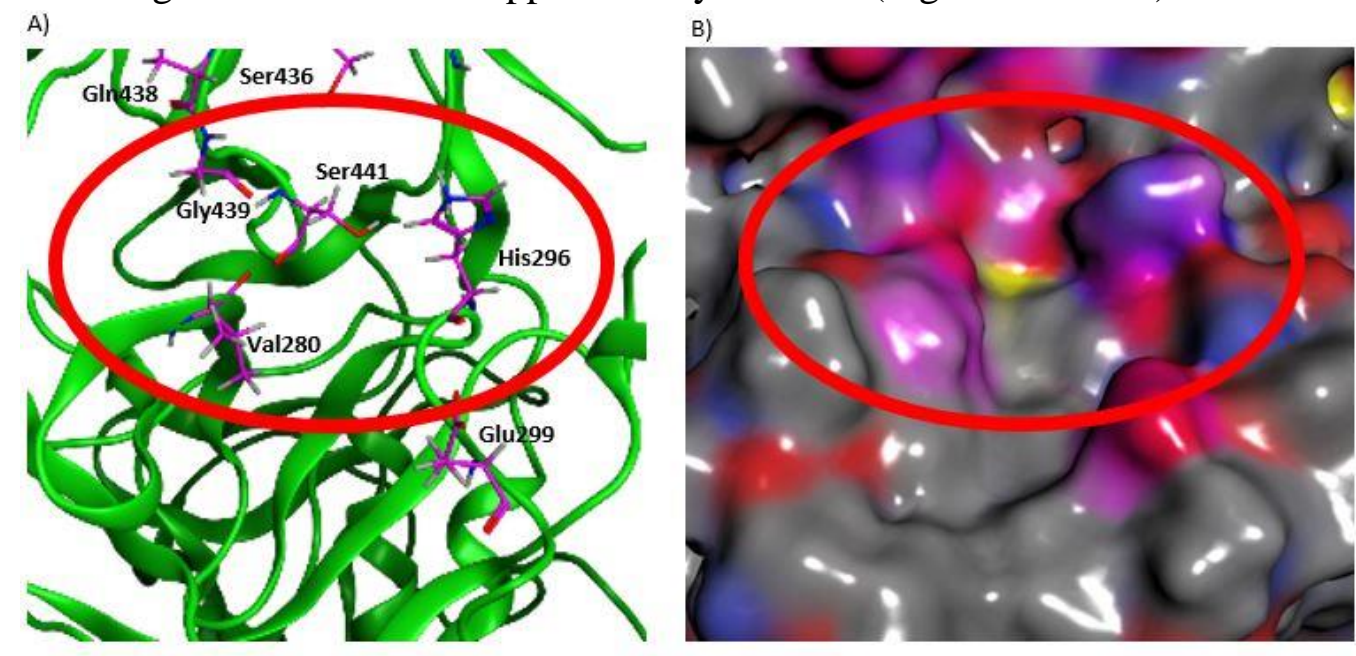

Figure 2. Potential site with some amino acids, the Ser441, is essential for the catalytic site. A) Val280, His296, Gly439, and Ser441 (Pink) into the red circle, and B) Pocket is displayed in the catalytic site.

\subsection{Discussion.}

The development of specific drugs against different targets in COVID-19 continues today. This study proposes compounds with a better inhibitory effect in the TMPRSS2 protease, thus hindering the infectious process of SARS-CoV-2 by decreasing the ability to fuse with the cell membrane. The expression of TMPRSS2 has been determined in different diseases such as influenza and prostate cancer (its expression increases), but it has taken an important role in COVID-19 in identifying its functions and level of expression in different tissues, with greater presence in the cell membrane of the epithelial cells of the lung and more intensely in the cells of the bronchial epithelium. TMPRSS2 has been identified to contribute to the cell membrane fusion process in the pathogenesis of COVID-19 [37, 39], as well as the 
factors that increase or decrease its expression in the cell membrane can be considered; in different populations [34, 35], according to gender (women or men by androgens [33]) or treatments that decrease its mRNA [36], and compounds/drugs that could inhibit the activity of this protease from preventing fusion with the cell membrane [24, 33, 36, 37], to be used against COVID-19.

This study proposes ten compounds with a better interaction in the catalytic site of TMPRSS2, using a homology model to establish a putative 3D structure of TMPRSS2 [55] and performing molecular docking using about 500,000 compounds. Ten compounds (T1 - T10) were determined with better average interaction value than ombitasvir, daclatasvir [42], otamixaban, argatroban, letaxaban, darexaban, edoxaban [39], bromhexine [38, 40, 41, 54], otamixaban NCGC00385043, NCGC00386945, NCGC00386477 [40], camostat, nafamostat, gabexate, and sivelestat [55] (Table 2). It is proposing that the inhibitory effect of T1 - T10 compounds could be, due to a better interaction with amino acids in the catalytic site (His296 and Ser441), with better affinity with Val280, Gly439, and Cys465 (Table 3), to generate more interactions with His296 and closely of Ser441, that are necessary for TMPRSS2 protease activity $[38,40,55]$.

To justify this study, it is necessary to emphasize the Ser441 in TMRPSS2. The data in Table 3 clearly show that the conformers from the T1 - T10 compounds have greater interaction with Val280, His296, and Cys465. These amino acids are important for the formation of interactions (mainly hydrogen bridges), and that the $\mathrm{T} 1$ - T10 compounds interact in the region of the catalytic site with Gly439 and very close to Ser441 (Figure 2); therefore, these compounds might hinder/block the accessibility or exposition of Ser441. The best interaction of all conformers from the compounds with Val280, His296, Gly439, and Cys465, generate the better averages of $\Delta$ Gbinding for these ten compounds.
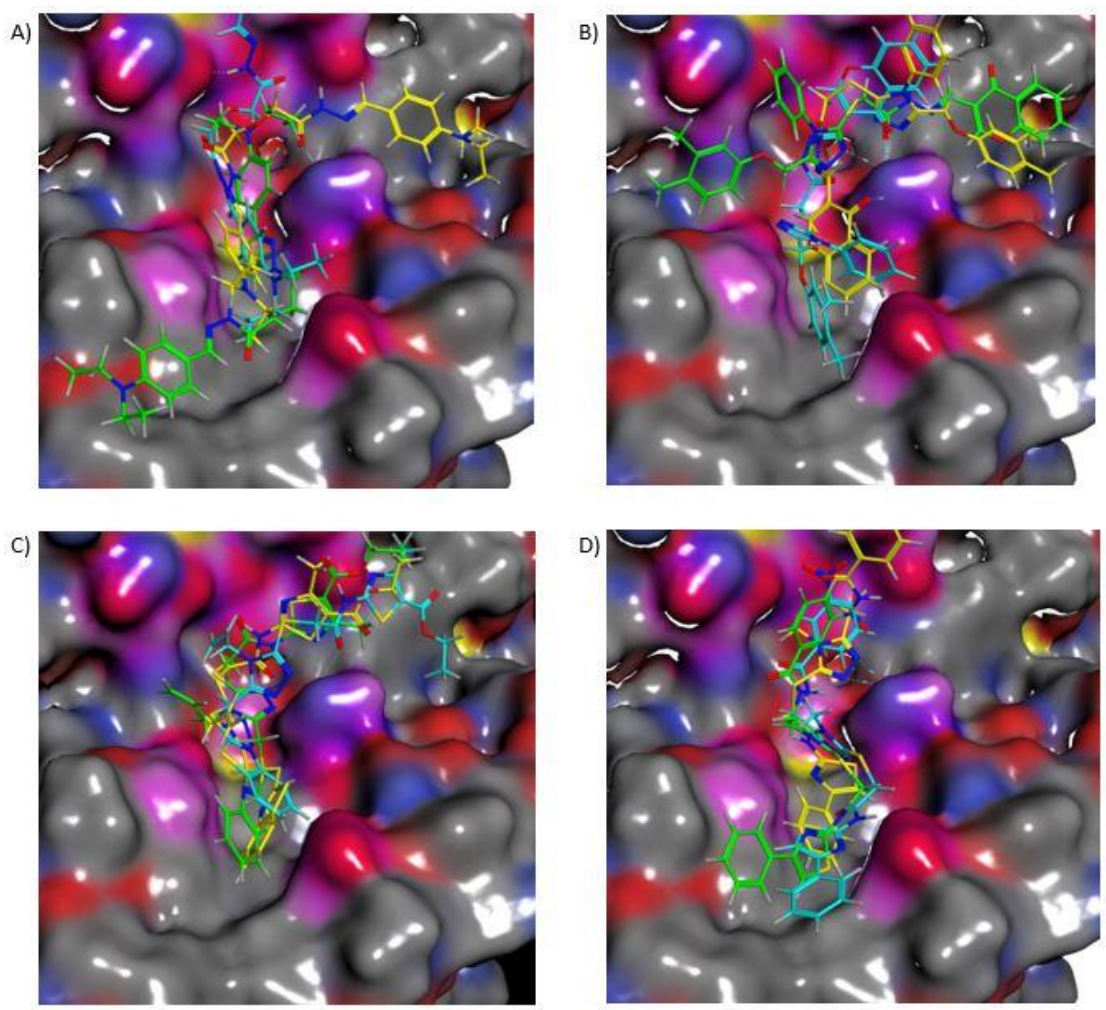

Figure 3. Three conformers (Yellow, Green, and Blue) from each compound interact in the potential site, Val280, His296, Gly439, Ser441, and Cys465 (Pink). A) T1, B) T2, C) T3, and D) T4. 
To demonstrate the above, it is shown the interaction of T1 - T4 compounds with three conformations, each one interacting in the potential site proposed (Figure 3), the amino acids Val280 his296, Gly339, Ser441, and Cys465 are shown, where it is proposed that these amino acids are contributing to get a better $\Delta$ Gbinding with TMPRSS2. In addition, the interaction of Daclatasvir, Ombitasvir, Camostat, and Nafamostat with three conformations each one is shown (Figure 4), these compounds/drugs show fewer interactions with Val280, His296, Gly439, and Cys465, which is related to a weaker interaction in the catalytic site (Table 2 and $3)$. The interactions of all compounds/drugs studied (with their conformers) in the potential site are shown in Figures S1 - S25, as well as the interactions between each conformer in the potential site are shown in Tables $\mathrm{S} 2-\mathrm{S} 26$. These results can contribute to developing a drug against COVID-19, designed to avoid or decrease the fusion between SARS-CoV-2 and the cell membrane.
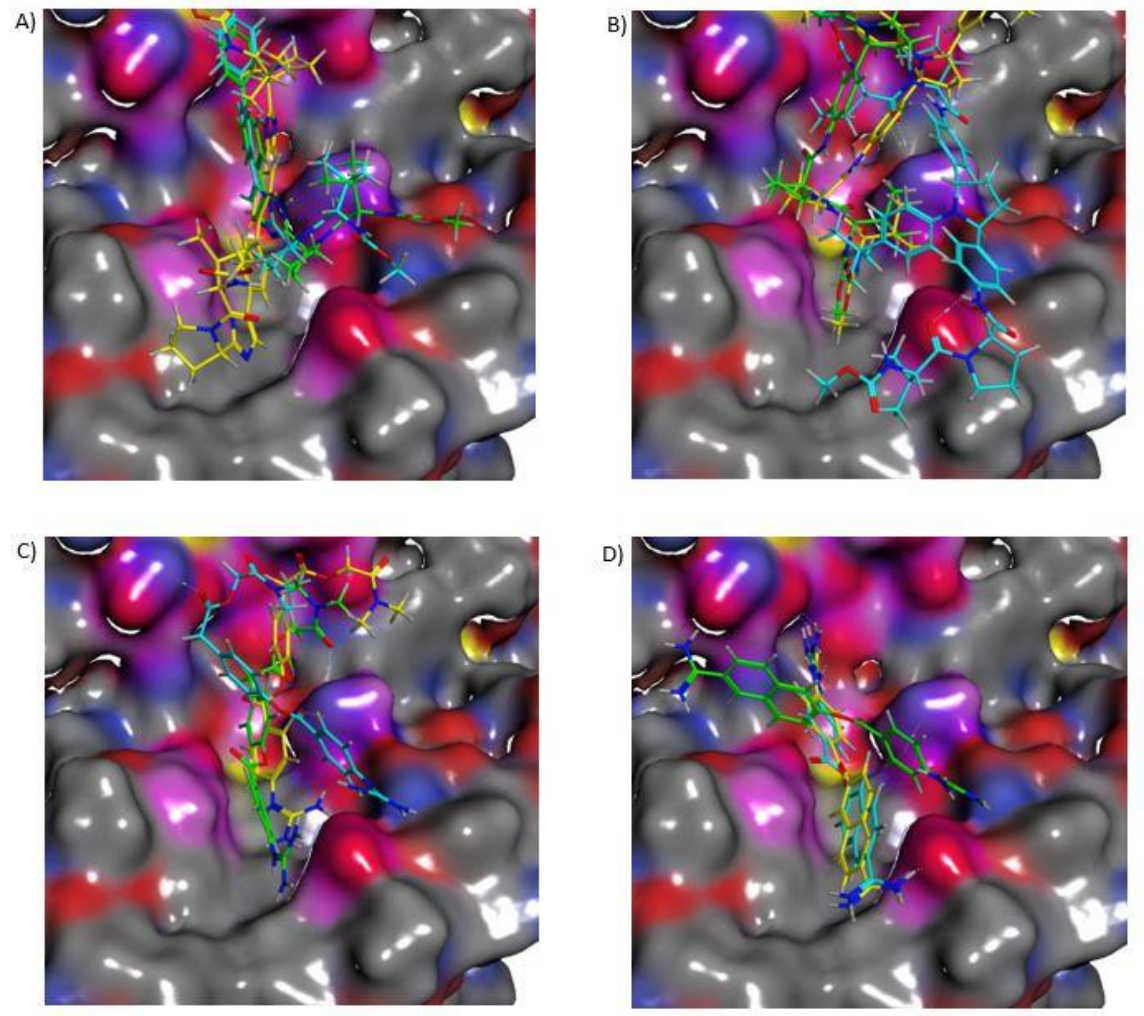

Figure 4. Three conformers (Yellow, Green, and Blue) from each compound interact in the potential site, Val280, His296, Gly439, Ser441, and Cys465 (Pink). A) Daclatasvir, B) Ombitasvir, C) Camostat, and D) Nafamostat.

On the other hand, the development of treatments with more advances is vaccines/antibodies [43-46]. However, there are reports of mutations at different proteins in the SARS-CoV-2 that could difficult their effectivity [46, 47], for example, in the S-protein of SARS-CoV-2 (December 2020) that could increase the infectious process and decrease the effect of vaccines [48 - 50], in which it is reported that the mutation E484K could generate resistance to several monoclonal antibodies, and the mutation N501Y could generate a greater interaction between RBD (S-protein) with ACE2, in which there are variants of the virus in the world that are related to more transmissibility and lethality of SARS-CoV-2 [52, 53]. In addition, vaccines have good opinions, but sometimes these have adverse reactions. The most common systemic adverse reaction was fatigue, fever, body pain, and a worse or lower immune response to vaccines in the elderly than in the younger population [75, 76], even some death [77]. Nevertheless, the development of vaccines continues with an acceptable safety and 
efficacy profile against COVID-19, despite the adverse effects that could occur in patients and the mutations that could reduce their effectiveness.

The development of non-antiviral drugs against COVID-19 may be a way to attack this virus since it would prevent the interaction between SARS-CoV-2 with proteins at the cell membrane (as receptors for S-protein). The use of these drugs could be an adjuvant treatment that helps the immune system generate antibodies and resist this disease, which depends on factors and comorbidities in each person. These membrane receptors could be ACE2 [16, 35, 78], NRP1 [22, 23, 79, 80], and TMPRSS2 [24, 33, 37]. These three receptors could be the key to blocking the entry of SARS-CoV-2 (Figure 5). It could prevent/hinder the entry of the SARSCoV-2 virus. With this approach, a combination of drugs could be developed as a new or complementary drug to use with conventional drugs and/or when using vaccines. But why would a combination of three drugs against COVID-19 be better? Each of these therapeutic targets (ACE2, NRP1, and TMPRSS2) are in the cell membrane that can generate advantages against antiviral drugs that have to cross the cell membrane. Some of these drugs/compounds already have toxicity results and/or have some reported use. This would facilitate experimental trials to try to make combinations between these three types of drugs, with different therapeutic targets, and that these interactions with their receptors, can generate summation or synergistic effects since there are currently reports of IC50 of some of them, with which estimates of their therapeutic effects could be made.

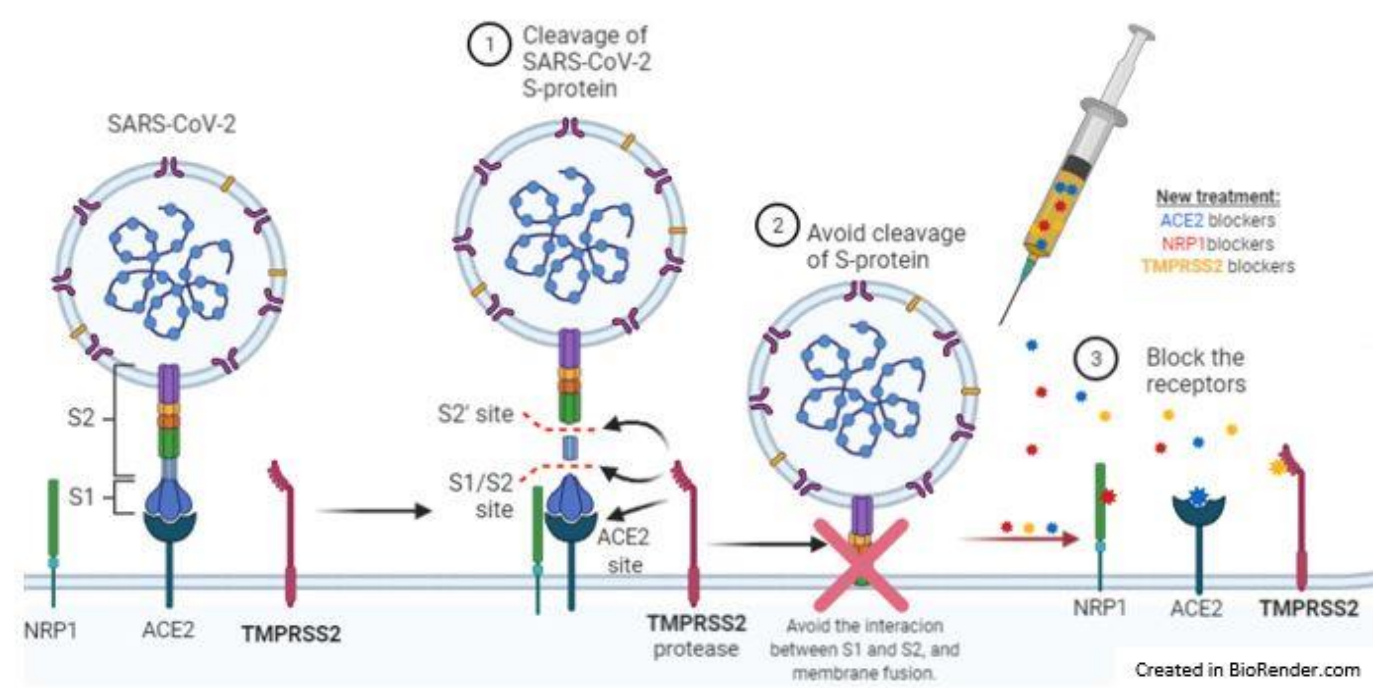

Figure 5. Blocking the interaction between S-protein of SARS-CoV-2 with its receptors (ACE2, NRP1, and TMPRSS2).

It would be necessary to evaluate the future effects of this proposal, a combination of potential compounds/drugs interacting with these three receptors on the cell membrane, could generate synergy with antiviral drugs, vaccines, or antibodies. In addition, these three receptors could have a better therapeutic effect than selective drugs, which is currently a disadvantage of the use of vaccines [48 - 50].

\section{Conclusions}

The development of an effective treatment against COVID-19 is still under development in the world. This study proposes ten compounds (T1 - T10) to develop a new drug to inhibit the activity protease of TMPRSS2, and it will be another way to attend COVID19. 
This therapeutic target has a significant role at COVID-19, as a cofactor for the infectious process, endosome formation, and internal management of viral material [24, 32]; therefore, the development of a selective drug for this therapeutic target would have the capacity to be an adjuvant or alternative treatment against COVID-19.

These ten compounds with a better interaction than previous compounds/drugs reported (Table 2 and 3) because T1 - T10 compounds have a better interaction with amino acids in the catalytic site (His296 and Ser441), due to the better affinity with Val280, Gly439 and Cys465 to generate more interactions with His296 and closely of Ser441, that are necessary for TMPRSS2 protease activity [38, 40, 55]. Moreover, the ten compounds have good results in theoretical toxicity servers.

\section{Funding}

This research received no external funding.

\section{Acknowledgments}

The author is very grateful for the financial support from PRODEP-SEP, SNI-CONACyT, FMM-UABC, and Dr. José Manuel Avendaño Reyes.

\section{Conflicts of Interest}

The author declares that he has no conflict of interest.

\section{Supplementary Data}

Supporting information includes figures and tables of interactions for compounds with TMPRSS2 and details of the interaction of each compound with TMPRSS2 per amino acid, theoretical toxicity results, ADME characteristics, and physical chemistry that support the information given in the results and discussion.

\section{References}

1. University, J.H. COVID-19 Dashboard by the Center for Systems Science and Engineering (CSSE) at Johns Hopkins University (JHU) Available online: https://coronavirus.jhu.edu/map.html.

2. Zhao, J.; Li, X.; Gao, Y.; Huang, W. Risk factors for the exacerbation of patients with 2019 Novel Coronavirus: A meta-analysis. International journal of medical sciences 2020, 17, 1744-1750, https://doi.org/10.7150/ijms.47052.

3. de Wit, E.; van Doremalen, N.; Falzarano, D.; Munster, V.J. SARS and MERS: recent insights into emerging coronaviruses. Nature reviews. Microbiology 2016, 14, 523-34, https://doi.org/10.1038/nrmicro.2016.81.

4. Guan, W.; Ni, Z.; Hu, Y.; Liang, W.; Ou, C.; He, J.; Liu, L.; Shan, H.; Lei, C.; Hui, D.S.C.; Du, B.; Li, L.; Zeng, G.; Yuen, K.; Chen, R.; Tang, C.; Wang, T.;Chen, P.; Xiang, J.; Li, S.; Wang, J.; Liang, J.; Peng, Y.; Wei, L.; Liu, Y.; Hu, Y.; Peng, P.; Wang, J.; Liu, J.; Chen, Z.; Li, G.; Zheng, Z.; Qiu, S.; Luo, J.; Ye, C.; Zhu, S.; Zhong, N. Clinical Characteristics of Coronavirus Disease 2019 in China. New England Journal of Medicine 2020, 382, 1708-1720, https://doi.org/10.1056/NEJMoa2002032.

5. Hu, Y.; Sun, J.; Dai, Z.; Deng, H.; Li, X.; Huang, Q.; Wu, Y.; Sun, L.; Xu, Y. Prevalence and severity of corona virus disease 2019 (COVID-19): A systematic review and meta-analysis. Journal of clinical virology: the official publication of the Pan American Society for Clinical Virology 2020, 127, 104371, https://doi.org/10.1016/j.jcv.2020.104371.

6. Wang, M.; Cao, R.; Zhang, L.; Yang, X.; Liu, J.; Xu, M.; Shi, Z.; Hu, Z.; Zhong, W.; Xiao, G. Remdesivir and chloroquine effectively inhibit the recently emerged novel coronavirus (2019-nCoV) in vitro. Cell Research 2020, 30, 269-271, https://doi.org/10.1038/s41422-020-0282-0.

7. Sheahan, T.P.; Sims, A.C.; Leist, S.R.; Schäfer, A.; Won, J.; Brown, A.J.; Montgomery, S.A.; Hogg, A.; Babusis, D.; Clarke, M.O.; Spahn, J.E.; Bauer, L.; Sellers, S.; Porter, D.; Feng, J.Y.; Cihlar, T.; Jordan, R.; Denison, M.R.; Baric, R.S. Comparative therapeutic efficacy of remdesivir and combination lopinavir, 
ritonavir, and interferon beta against MERS-CoV. Nature Communications 2020, 11, 222, https://doi.org/10.1038/s41467-019-13940-6.

8. Li, G.; De Clercq, E. Therapeutic options for the 2019 novel coronavirus (2019-nCoV). Nature Reviews Drug Discovery 2020, 19, 149-150, https://doi.org/10.1038/d41573-020-00016-0.

9. Iftikhar, H.; Ali, H.N.; Farooq, S.; Naveed, H.; Shahzad-ul-Hussan, S. Identification of potential inhibitors of three key enzymes of SARS-CoV2 using computational approach. Computers in Biology and Medicine 2020, 122, 103848, https://doi.org/10.1016/j.compbiomed.2020.103848.

10.Wu, C.; Liu, Y.; Yang, Y.; Zhang, P.; Zhong, W.; Wang, Y.; Wang, Q.; Xu, Y.; Li, M.; Li, X.; Zheng, M.; Chen, L.; Li, H. Analysis of therapeutic targets for SARS-CoV-2 and discovery of potential drugs by computational methods. Acta Pharmaceutica Sinica B 2020, 10, 766-788, https://doi.org/10.1016/j.apsb.2020.02.008.

11.Xia, S.; Yan, L.; Xu, W.; Agrawal, A.S.; Algaissi, A.; Tseng, C.-T.K.; Wang, Q.; Du, L.; Tan, W.; Wilson, I.A.; Jiang, S.; Yang, B.; Lu, L. A pan-coronavirus fusion inhibitor targeting the HR1 domain of human coronavirus spike. Science advances 2019, 5, eaav4580, https://doi.org/10.1126/sciadv.aav4580.

12.Xia, S.; Liu, M.; Wang, C.; Xu, W.; Lan, Q.; Feng, S.; Qi, F.; Bao, L.; Du, L.; Liu, S.; Qin, C.; Sun, F.; Shi, Z.; Zhu, Y.; Jiang, S.; Lu, L. Inhibition of SARS-CoV-2 (previously 2019-nCoV) infection by a highly potent pan-coronavirus fusion inhibitor targeting its spike protein that harbors a high capacity to mediate membrane fusion. Cell Research 2020, 30, 343-355, https://doi.org/10.1038/s41422-020-0305-X.

13. Calligari, P.; Bobone, S.; Ricci, G.; Bocedi, A. Molecular Investigation of SARS-CoV-2 Proteins and Their Interactions with Antiviral Drugs. Viruses 2020, 12, 445, https://doi.org/10.3390/v12040445.

14.Huang, J.; Song, W.; Huang, H.; Sun, Q. Pharmacological Therapeutics Targeting RNA-Dependent RNA Polymerase, Proteinase and Spike Protein: From Mechanistic Studies to Clinical Trials for COVID-19. Journal of Clinical Medicine 2020, 9, 1131, https://doi.org/10.3390/jcm9041131.

15. Vankadari, N. Arbidol: A potential antiviral drug for the treatment of SARS-CoV-2 by blocking trimerization of the spike glycoprotein. International Journal of Antimicrobial Agents 2020, 105998, https://doi.org/10.1016/j.ijantimicag.2020.105998.

16. Benítez-Cardoza, C.G.; Vique-Sánchez, J.L. Potential inhibitors of the interaction between ACE2 and SARSCoV-2 (RBD), to develop a drug. Life Sciences 2020, 256, 117970, https://doi.org/10.1016/j.lfs.2020.117970.

17. Khelfaoui, H.; Harkati, D.; Saleh, B.A. Molecular docking, molecular dynamics simulations and reactivity, studies on approved drugs library targeting ACE2 and SARS-CoV-2 binding with ACE2. Journal of Biomolecular Structure and Dynamics 2020, 1-17, https://doi.org/10.1080/07391102.2020.1803967.

18. Grifoni, A.; Sidney, J.; Zhang, Y.; Scheuermann, R.H.; Peters, B.; Sette, A. A Sequence Homology and Bioinformatic Approach Can Predict Candidate Targets for Immune Responses to SARS-CoV-2. Cell Host \& Microbe 2020, https://doi.org/10.1016/j.chom.2020.03.002.

19.Ton, A.-T.; Gentile, F.; Hsing, M.; Ban, F.; Cherkasov, A. Rapid Identification of Potential Inhibitors of SARSCoV-2 Main Protease by Deep Docking of 1.3 Billion Compounds. Molecular Informatics 2020, 39, 2000028, https://doi.org/10.1002/minf.202000028.

20.Zhang, L.; Lin, D.; Sun, X.; Curth, U.; Drosten, C.; Sauerhering, L.; Becker, S.; Rox, K.; Hilgenfeld, R. Crystal structure of SARS-CoV-2 main protease provides a basis for design of improved $\alpha$-ketoamide inhibitors. Science 2020, 368, 409-412, https://doi.org/10.1126/science.abb3405.

21. Benítez-Cardoza, C.G.; Vique-Sánchez, J.L. Identifying compounds that prevent the binding of the SARSCoV-2 S-protein to ACE2. Computers in Biology and Medicine 2021, 136, 104719, https://doi.org/10.1016/j.compbiomed.2021.104719.

22.Perez-Miller, S.; Patek, M.; Moutal, A.; Cabel, C.R.; Thorne, C.A.; Campos, S.K.; Khanna, R. In silico identification and validation of inhibitors of the interaction between neuropilin receptor 1 and SARS-CoV-2 Spike protein. bioRxiv : the preprint server for biology 2020, https://doi.org/10.1101/2020.09.22.308783.

23. Vique-Sánchez, J.L. Potential inhibitors interacting in Neuropilin-1 to develop an adjuvant drug against COVID-19, by molecular docking. Bioorganic and Medicinal Chemistry 2021, 33, 116040, https://doi.org/10.1016/j.bmc.2021.116040.

24.Hoffmann, M.; Kleine-Weber, H.; Schroeder, S.; Krüger, N.; Herrler, T.; Erichsen, S.; Schiergens, T.S.; Herrler, G.; Wu, N.-H.; Nitsche, A.; Müller, M.A.; Drosten, C.; Pöhlmann, S.. SARS-CoV-2 Cell Entry Depends on ACE2 and TMPRSS2 and Is Blocked by a Clinically Proven Protease Inhibitor. Cell 2020, 181, 271-280, https://doi.org/10.1016/j.cell.2020.02.052.

25.Stopsack, K.H.; Mucci, L.A.; Antonarakis, E.S.; Nelson, P.S.; Kantoff, P.W. TMPRSS2 and COVID-19: Serendipity or Opportunity for Intervention? Cancer Discovery 2020, 10, 779-782, https://doi/10.1158/21598290.CD-20-0451.

26.Lau, S.-Y.; Wang, P.; Mok, B.W.-Y.; Zhang, A.J.; Chu, H.; Lee, A.C.-Y.; Deng, S.; Chen, P.; Chan, K.-H.; Song, W.; Chen, Z.; Kai-Wang To, K.; Chan, J.F-W.; Yuen, K-Y.; Chen, H. Attenuated SARS-CoV-2 variants with deletions at the S1/S2 junction. Emerging Microbes \& Infections 2020, 9, 837-842, https://doi.org/10.1080/22221751.2020.1756700.

27.Abuo-Rahma, G.E.-D.A.; Mohamed, M.F.A.; Ibrahim, T.S.; Shoman, M.E.; Samir, E.; Abd El-Baky, R.M. Potential repurposed SARS-CoV-2 (COVID-19) infection drugs. RSC Advances 2020, 10, 26895-26916, https://doi.org/10.1039/D0RA05821A. 
28. Vitiello, A.; La Porta, R.; Ferrara, F. Scientific hypothesis and rational pharmacological for the use of sacubitril/valsartan in cardiac damage caused by COVID-19. Medical Hypotheses 2021, 147, 110486, https://doi.org/10.1016/j.mehy.2021.110486.

29. Souza, P.F.N.; Lopes, F.E.S.; Amaral, J.L.; Freitas, C.D.T.; Oliveira, J.T.A. A molecular docking study revealed that synthetic peptides induced conformational changes in the structure of SARS-CoV-2 spike glycoprotein, disrupting the interaction with human ACE2 receptor. International Journal of Biological Macromolecules 2020, 164, 66-76, https://doi.org/10.1016/j.ijbiomac.2020.07.174.

30. BR, B.; Damle, H.; Ganju, S.; Damle, L. In silico screening of known small molecules to bind ACE2 specific RBD on Spike glycoprotein of SARS-CoV-2 for repurposing against COVID-19. F1000Research 2020, 9, 663, https://doi.org/10.12688/f1000research.24143.1.

31.Prajapat, M.; Shekhar, N.; Sarma, P.; Avti, P.; Singh, S.; Kaur, H.; Bhattacharyya, A.; Kumar, S.; Sharma, S.; Prakash, A.; Medhi, B. Virtual screening and molecular dynamics study of approved drugs as inhibitors of spike protein S1 domain and ACE2 interaction in SARS-CoV-2. Journal of Molecular Graphics and Modelling 2020, 101, 107716, https://doi.org/10.1016/j.jmgm.2020.107716.

32.Kielian, M. Enhancing host cell infection by SARS-CoV-2. Science 2020, 370, 765-766, https://doi.org/10.1126/science.abf0732.

33.Stopsack, K.H.; Mucci, L.A.; Antonarakis, E.S.; Nelson, P.S.; Kantoff, P.W. TMPRSS2 and COVID-19: Serendipity or Opportunity for Intervention? Cancer Discovery 2020, 10, 779-782, https://doi.org/10.1158/2159-8290.CD-20-0451.

34.Lanjanian, H.; Moazzam-Jazi, M.; Hedayati, M.; Akbarzadeh, M.; Guity, K.; Sedaghati-khayat, B.; Azizi, F.; Daneshpour, M.S. SARS-CoV-2 infection susceptibility influenced by ACE2 genetic polymorphisms: insights from Tehran Cardio-Metabolic Genetic Study. Scientific Reports 2021, 11, 1529, https://doi.org/10.1038/s41598-020-80325-X.

35.Yan, R.; Zhang, Y.; Li, Y.; Xia, L.; Guo, Y.; Zhou, Q. Structural basis for the recognition of the SARS-CoV2 by full-length human ACE2. Science 2020, 367, 1444-1448, https://doi.org/10.1126/science.abb2762.

36.Ragia, G.; Manolopoulos, V.G. Inhibition of SARS-CoV-2 entry through the ACE2/TMPRSS2 pathway: a promising approach for uncovering early COVID-19 drug therapies. European Journal of Clinical Pharmacology 2020, 76, 1623-1630, https://doi.org/10.1007/s00228-020-02963-4.

37.Bittmann, S.; Luchter, E.; Weissenstein, A.; Villalon, G.; Moschüring-Alieva, E. TMPRSS2-Inhibitors Play a role in Cell Entry Mechanism of COVID-19: An Insight into Camostat and Nafamostat. Journal of Regenerative Biology and Medicine 2020, 2, 1-3, https://doi.org/10.37191/Mapsci-2582-385X-2(2)-022.

38.Singh, N.; Decroly, E.; Khatib, A.-M.; Villoutreix, B.O. Structure-based drug repositioning over the human TMPRSS2 protease domain: search for chemical probes able to repress SARS-CoV-2 Spike protein cleavages. European Journal of Pharmaceutical Sciences 2020, 153, 105495, https://doi.org/10.1016/j.ejps.2020.105495.

39.Faheem; Kumar, B.K.; Sekhar, K.V.G.C.; Kunjiappan, S.; Jamalis, J.; Balaña-Fouce, R.; Tekwani, B.L.; Sankaranarayanan, M. Druggable targets of SARS-CoV-2 and treatment opportunities for COVID-19. Bioorganic Chemistry 2020, 104, 104269, https://doi.org/10.1016/j.bioorg.2020.104269.

40.Hu, X.; Shrimp, J.H.; Guo, H.; Xu, M.; Chen, C.Z.; Zhu, W.; Zakharov, A.; Jain, S.; Shinn, P.; Simeonov, A.; Hall, M.D.; Shen, M. Discovery of TMPRSS2 inhibitors from virtual screening V2. bioRxiv: the preprint server for biology 2020, https://doi.org/10.1101/2020.12.28.424413.

41.Al-Horani, R.A.; Kar, S.; Aliter, K.F. Potential Anti-COVID-19 Therapeutics that Block the Early Stage of the Viral Life Cycle: Structures, Mechanisms, and Clinical Trials. International Journal of Molecular Sciences 2020, 21, 5224, https://doi.org/10.3390/ijms21155224.

42.Choi, Y.; Shin, B.; Kang, K.; Park, S.; Beck, B.R. Target-Centered Drug Repurposing Predictions of Human Angiotensin-Converting Enzyme 2 (ACE2) and Transmembrane Protease Serine Subtype 2 (TMPRSS2) Interacting Approved Drugs for Coronavirus Disease 2019 (COVID-19) Treatment through a Drug-Target Interaction Deep Learning Model. Viruses 2020, 12, 1325, https://doi.org/10.3390/v12111325.

43.Liu, C.; Zhou, Q.; Li, Y.; Garner, L. V.; Watkins, S.P.; Carter, L.J.; Smoot, J.; Gregg, A.C.; Daniels, A.D.; Jervey, S.; Albaiu, D. Research and Development on Therapeutic Agents and Vaccines for COVID-19 and Related Human Coronavirus Diseases. ACS Central Science 2020, 6, 315-331, https://doi.org/10.1021/acscentsci.0c00272.

44.LOCHT, C. Vaccines against COVID-19. Anaesthesia Critical Care \& Pain Medicine 2020, 39, 703-705, https://doi.org/10.1016/j.accpm.2020.10.006.

45.Kim, K.-D.; Hwang, I.; Ku, K.B.; Lee, S.; Kim, S.-J.; Kim, C. Progress and Challenges in the Development of COVID-19 Vaccines and Current Understanding of SARS-CoV-2- Specific Immune Responses. Journal of Microbiology and Biotechnology 2020, 30, 1109-1115, https://doi.org/10.4014/jmb.2006.06006.

46.Weisblum, Y.; Schmidt, F.; Zhang, F.; DaSilva, J.; Poston, D.; Lorenzi, J.C.; Muecksch, F.; Rutkowska, M.; Hoffmann, H.-H.; Michailidis, E.; Gaebler, C.; Agudelo, M.; Cho, A.; Wang, Z.; Gazumyan, A.; Cipolla, M.; Luchsinger, L.; D Hillyer, C.; Caskey, M.; F Robbiani, D.; M Rice, C.; C Nussenzweig, M.; Hatziioannou, T.; D Bieniasz, P. Escape from neutralizing antibodies by SARS-CoV-2 spike protein variants. eLife 2020, 9, https://doi.org/10.7554/eLife.61312.

47.Li, Q.; Wu, J.; Nie, J.; Zhang, L.; Hao, H.; Liu, S.; Zhao, C.; Zhang, Q.; Liu, H.; Nie, L.; Qin, H.; Wang, M.; Lu, Q.; Li, X.; Sun, Q.; Liu, J.; Zhang, L.; Li, X.; Huang, W.; Wang, Y. The Impact of Mutations in SARS- 
CoV-2 Spike on Viral Infectivity and Antigenicity. Cell 2020, 182, 1284-1294.e9, https://doi.org/10.1016/j.cell.2020.07.012.

48.Conti, P.; Caraffa, A.; Gallenga, C.E.; Kritas, S.K.; Frydas, I.; Younes, A.; Di Emidio, P.; Tetè, G.; Pregliasco, F.; Ronconi, G. The British variant of the new coronavirus-19 (Sars-Cov-2) should not create a vaccine problem. Journal of biological regulators and homeostatic agents 2021, 35, 1-4, https://www.researchgate.net/profile/Pio-

Conti/publication/348804233_The_British_variant_of_the_new_coronavirus-19_Sars-Cov-

2_should_not_create_a_vaccine_problem/links/609e575a299bf1476996e590/The-British-variant-of-thenew-coronavirus-19-Sars-Cov-2-should-not-create-a-vaccine-problem.pdf

49.Santos, J.C.; Passos, G.A. The high infectivity of SARS-CoV-2 B.1.1.7 is associated with increased interaction force between Spike-ACE2 caused by the viral N501Y mutation. bioRxiv 2021, https://doi.org/10.1101/2020.12.29.424708.

50.Luan, B.; Wang, H.; Huynh, T. Molecular Mechanism of the N501Y Mutation for Enhanced Binding between SARS-CoV-2\{ltextquoteright $\}$ s Spike Protein and Human ACE2 Receptor. bioRxiv 2021, https://doi.org/10.1101/2021.01.04.425316.

51.Leung, K.; Shum, M.H.; Leung, G.M.; Lam, T.T.; Wu, J.T. Early transmissibility assessment of the N501Y mutant strains of SARS-CoV-2 in the United Kingdom, October to November 2020. Eurosurveillance 2021, 26, https://doi.org/10.2807/1560-7917.ES.2020.26.1.2002106.

52.Challen, R.; Brooks-Pollock, E.; Read, J.M.; Dyson, L.; Tsaneva-Atanasova, K.; Danon, L. Risk of mortality in patients infected with SARS-CoV-2 variant of concern 202012/1: matched cohort study. BMJ 2021, 372, n579, https://doi.org/10.1136/bmj.n579.

53.Xie, X.; Liu, Y.; Liu, J.; Zhang, X.; Zou, J.; Fontes-Garfias, C.R.; Xia, H.; Swanson, K.A.; Cutler, M.; Cooper, D.; Menachery, V.D.; Weaver, S.C.; Dormitzer, P.R.; Shi, P-Y. Neutralization of SARS-CoV-2 spike 69/70 deletion, E484K and N501Y variants by BNT162b2 vaccine-elicited sera. Nature Medicine 2021, 27, 620621, https://doi.org/10.1038/s41591-021-01270-4.

54.Maggio, R.; Corsini, G.U. Repurposing the mucolytic cough suppressant and TMPRSS2 protease inhibitor bromhexine for the prevention and management of SARS-CoV-2 infection. Pharmacological Research 2020, 157, 104837, https://doi.org/10.1016/j.phrs.2020.104837.

55.Kishk, S.M.; Kishk, R.M.; Yassen, A.S.A.; Nafie, M.S.; Nemr, N.A.; ElMasry, G.; Al-Rejaie, S.; Simons, C. Molecular Insights into Human Transmembrane Protease Serine-2 (TMPS2) Inhibitors against SARS-CoV2: Homology Modelling, Molecular Dynamics, and Docking Studies. Molecules 2020, 25, 5007, https://doi.org/10.3390/molecules25215007.

56.Swissmodel Available online: https://swissmodel.expasy.org/.

57.PDB: 1Z8G Available online: https://www.rcsb.org/structure/1Z8G.

58.UniProt Available online: https://www.uniprot.org/.

59.RAMPAGE (RRID:SCR_017590) Available online: https://scicrunch.org/resolver/RRID:SCR_017590.

60.Brooks, B.R.; Brooks, C.L.; Mackerell, A.D.; Nilsson, L.; Petrella, R.J.; Roux, B.; Won, Y.; Archontis, G.; Bartels, C.; Boresch, S.; Caflisch, A.; Caves, L.; Cui, Q.; Dinner, A. R.; Feig, M.; Fischer, S.; Gao, J.; Hodoscek, M.; Im, W.; Kuczera, K.; Lazaridis, T.; Ma, J.; Ovchinnikov, V.; Paci, E.; Pastor, R. W.; Post, C. B.; Pu, J. Z.; Schaefer, M.; Tidor, B.; Venable, R. M.; Woodcock, H. L.; Wu, X.; Yang, W.; York, D. M.; Karpluset, M. CHARMM: The biomolecular simulation program. Journal of Computational Chemistry 2009, 30, 1545-1614, https://doi.org/10.1002/jcc.21287.

61.Halgren, T.A. Merck molecular force field. I. Basis, form, scope, parameterization, and performance of MMFF94. Journal of Computational Chemistry 1996, 17, 490-519, https://doi.org/10.1002/(SICI)1096987X(199604)17:5/6<490::AID-JCC1>3.0.CO;2-P.

62.Corporation, ChemBridge Available online: http://www.chembridge.com/screening_libraries/.

63.Lipinski, C.A.; Lombardo, F.; Dominy, B.W.; Feeney, P.J. Experimental and computational approaches to estimate solubility and permeability in drug discovery and development settings. Advanced drug delivery reviews 1997, 23, 3-25, https://doi.org/10.1016/S0169-409X(96)00423-1.

64.Thangapandian, S.; John, S.; Lee, Y.; Kim, S.; Lee, K.W. Dynamic Structure-Based Pharmacophore Model Development: A New and Effective Addition in the Histone Deacetylase 8 (HDAC8) Inhibitor Discovery. International Journal of Molecular Sciences 2011, 12, 9440-9462, https://doi.org/10.3390/ijms12129440.

65. Morris, G.M.; Huey, R.; Lindstrom, W.; Sanner, M.F.; Belew, R.K.; Goodsell, D.S.; Olson, A.J. AutoDock4 and AutoDockTools4: Automated docking with selective receptor flexibility. Journal of Computational Chemistry 2009, 30, 2785-2791, https://doi:10.1002/jcc.21256.

66.Protein-Ligand Interaction Profiler Available online: https://plip-tool.biotec.tu-dresden.de/plipweb/plip/index.

67.Salentin, S.; Schreiber, S.; Haupt, V.J.; Adasme, M.F.; Schroeder, M. PLIP: fully automated protein-ligand interaction profiler. Nucleic Acids Research 2015, 43, W443-W447, https://doi.org/10.1093/nar/gkv315.

68.Soga, S.; Shirai, H.; Kobori, M.; Hirayama, N. Use of Amino Acid Composition to Predict Ligand-Binding Sites. Journal of Chemical Information and Modeling 2007, 47, 400-406, https://doi.org/10.1021/ci6002202.

69.Labute, P. The generalized Born/volume integral implicit solvent model: estimation of the free energy of hydration using London dispersion instead of atomic surface area. Journal of computational chemistry $\mathbf{2 0 0 8}$, 
29, 1693-1698, https://doi.org/10.1002/jcc.20933.

70.Wadood, A.; Ghufran, M.; Hassan, S.F.; Khan, H.; Azam, S.S.; Rashid, U. In silico identification of promiscuous scaffolds as potential inhibitors of 1-deoxy- $d$-xylulose 5-phosphate reductoisomerase for treatment of Falciparum malaria. Pharmaceutical Biology 2017, 55, 19-32, https://doi.org/10.1080/13880209.2016.1225778.

71.PhysChem, ADME \& Toxicity, version 2021.1.1, Advanced Chemistry Development, Inc., Toronto, ON, Canada, www.acdlabs.com, 2021.

72.ADMETlab Available online: http://admet.scbdd.com/calcpre/index_sys/.

73.PreADMET Available online: https://preadmet.bmdrc.kr/toxicity/.

74.ProTox-II - $\quad$ Prediction of TOXicity Available http://tox.charite.de/protox_II/index.php?site=compound_input.

75.Xing, K.; Tu, X.-Y.; Liu, M.; Liang, Z.-W.; Chen, J.-N.; Li, J.-J.; Jiang, L.-G.; Xing, F.-Q.; Jiang, Y. Efficacy and safety of COVID-19 vaccines: a systematic review. Zhongguo dang dai er ke za zhi = Chinese journal of contemporary pediatrics 2021, 23, 221-228, https://doi.org/10.7499/j.issn.1008-8830.2101133.

76.Yuan, P.; Ai, P.; Liu, Y.; Ai, Z.; Wang, Y.; Cao, W.; Xia, X.; Zheng, J.C. Safety, Tolerability, and Immunogenicity of COVID-19 Vaccines: A Systematic Review and Meta-Analysis. medRxiv 2020, https://doi.org/10.1101/2020.11.03.20224998.

77.Voysey, M.; Clemens, S.A.C.; Madhi, S.A.; Weckx, L.Y.; Folegatti, P.M.; Aley, P.K.; Angus, B.; Baillie, V.L.; Barnabas, S.L.; Bhorat, Q.E.; et al. Safety and efficacy of the ChAdOx1 nCoV-19 vaccine (AZD1222) against SARS-CoV-2: an interim analysis of four randomised controlled trials in Brazil, South Africa, and the UK. The Lancet 2020, 397, 99-111, https://doi.org/10.1016/S0140-6736(20)32661-1.

78.Han, D.P.; Penn-Nicholson, A.; Cho, M.W. Identification of critical determinants on ACE2 for SARS-CoV entry and development of a potent entry inhibitor. Virology 2006, 350, 15-25, https://doi.org/10.1016/j.virol.2006.01.029.

79.Cantuti-Castelvetri, L.; Ojha, R.; Pedro, L.D.; Djannatian, M.; Franz, J.; Kuivanen, S.; van der Meer, F.; Kallio, K.; Kaya, T.; Anastasina, M.; et al. Neuropilin-1 facilitates SARS-CoV-2 cell entry and infectivity. Science 2020, 370, 856-860, https://doi.org/10.1126/science.abd2985.

80.Daly, J.L.; Simonetti, B.; Klein, K.; Chen, K.-E.; Williamson, M.K.; Antón-Plágaro, C.; Shoemark, D.K.; Simón-Gracia, L.; Bauer, M.; Hollandi, R.; et al. Neuropilin-1 is a host factor for SARS-CoV-2 infection. Science 2020, 370, 861-865, https://doi.org/10.1126/science.abd3072. 


\section{Supplementary materials}
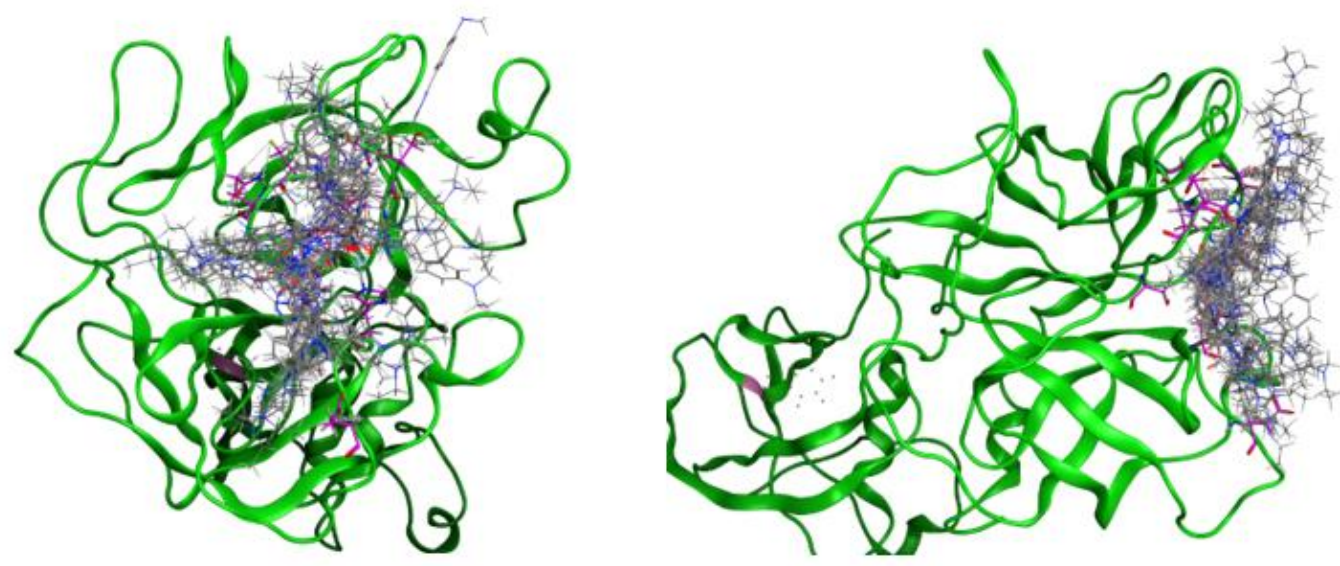

Figure S1. TMPRSS2 (Green) shows amino acids His296, Glu299, Asp435, Ser436, Cys437, Gln438, Ser441, Gly462, Ser463, and Gly464 (Pink) as region chosen for docking with 29 conformers of compound T1 (Gray).
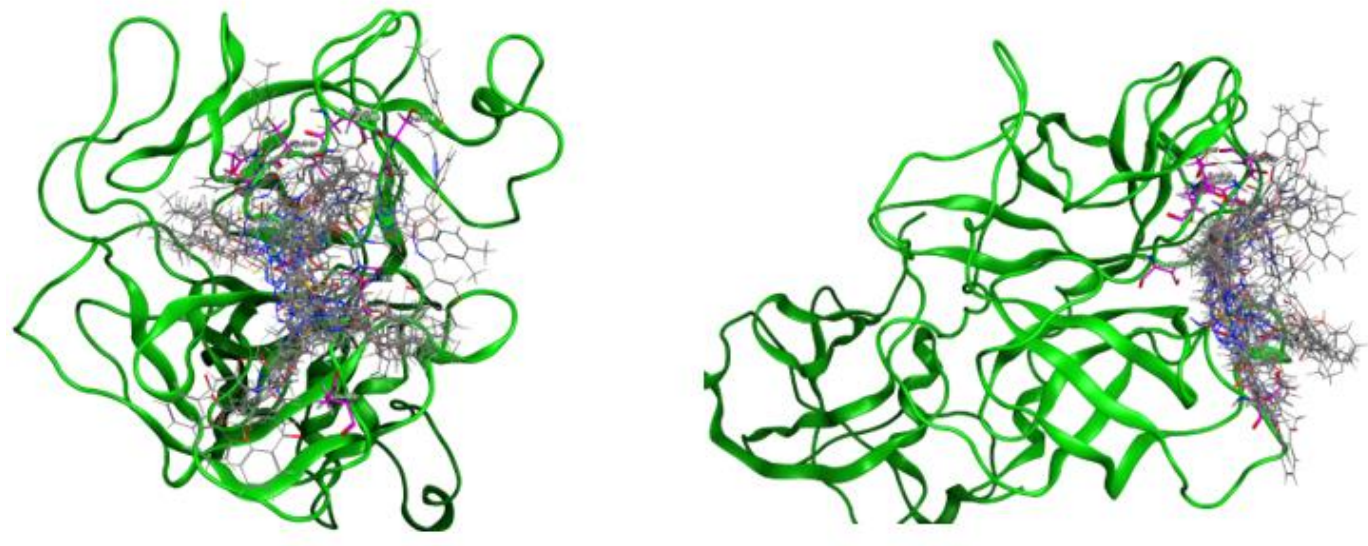

Figure S2. TMPRSS2 (Green) shows amino acids His296, Glu299, Asp435, Ser436, Cys437, Gln438, Ser441, Gly462, Ser463, and Gly464 (Pink) as region chosen for docking with 28 conformers of compound T2 (Gray).
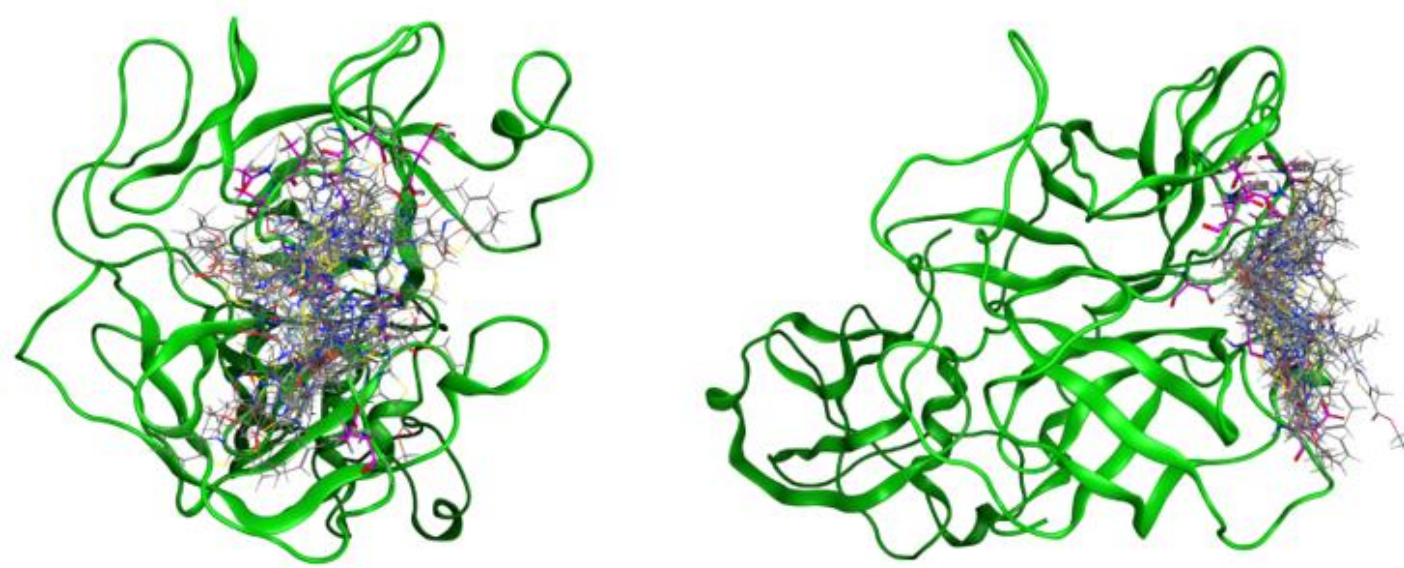

Figure S3. TMPRSS2 (Green) shows amino acids His296, Glu299, Asp435, Ser436, Cys437, Gln438, Ser441, Gly462, Ser463, and Gly464 (Pink) as region chosen for docking with 24 conformers of compound T3 (Gray). 

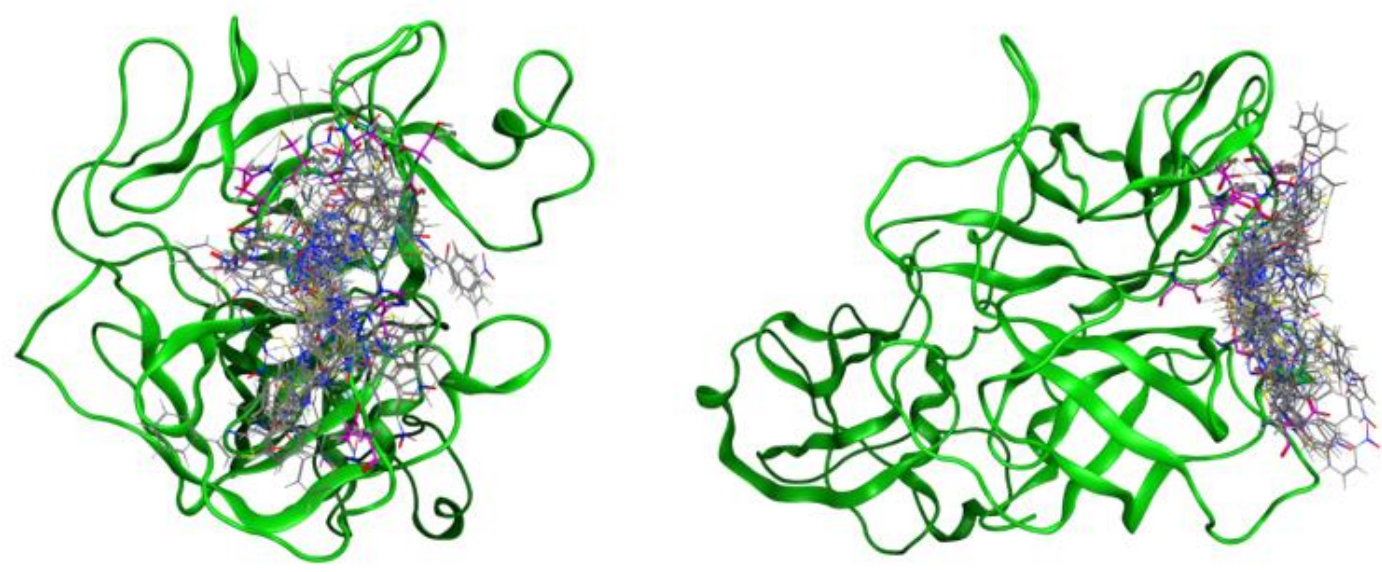

Figure S4. TMPRSS2 (Green) shows amino acids His296, Glu299, Asp435, Ser436, Cys437, Gln438, Ser441, Gly462, Ser463, and Gly464 (Pink) as region chosen for docking with 29 conformers of compound T4 (Gray).
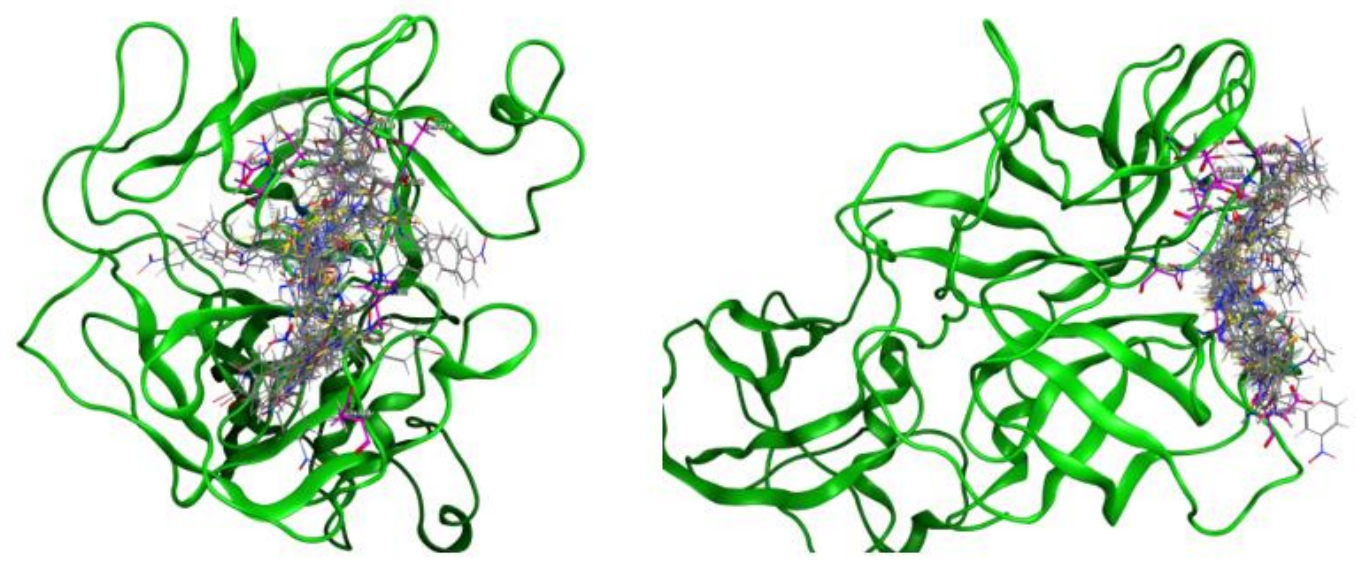

Figure S5. TMPRSS2 (Green) shows amino acids His296, Glu299, Asp435, Ser436, Cys437, Gln438, Ser441, Gly462, Ser463, and Gly464 (Pink) as region chosen for docking with 26 conformers of compound T5 (Gray).
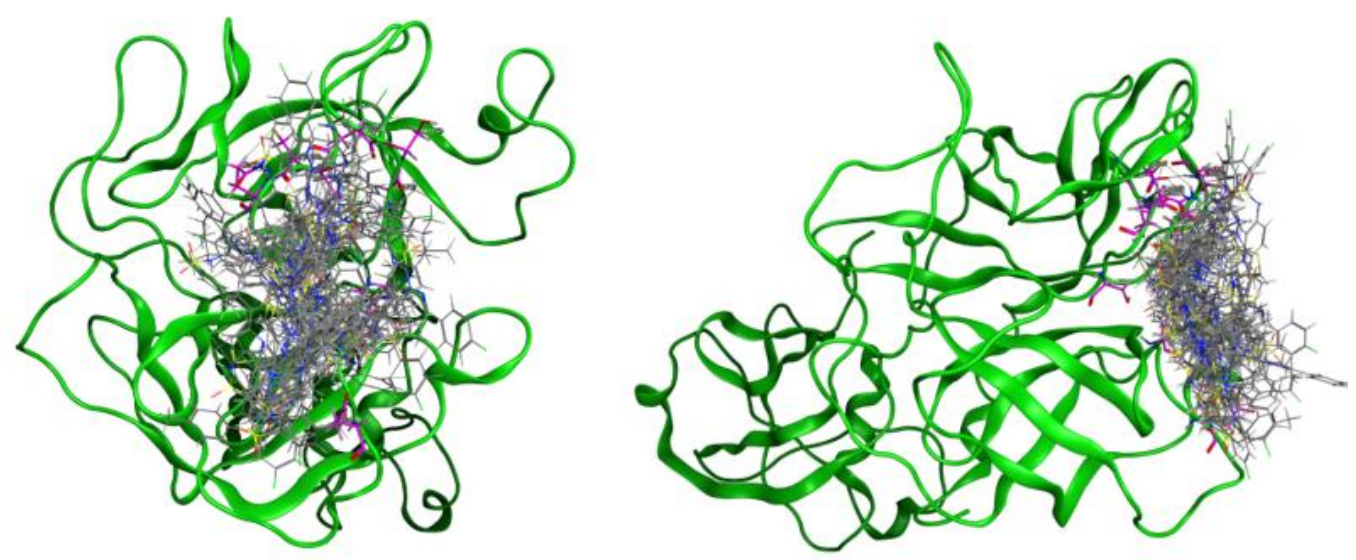

Figure S6. TMPRSS2 (Green) shows amino acids His296, Glu299, Asp435, Ser436, Cys437, Gln438, Ser441, Gly462, Ser463, and Gly464 (Pink) as region chosen for docking with 27 conformers of compound T6 (Gray). 

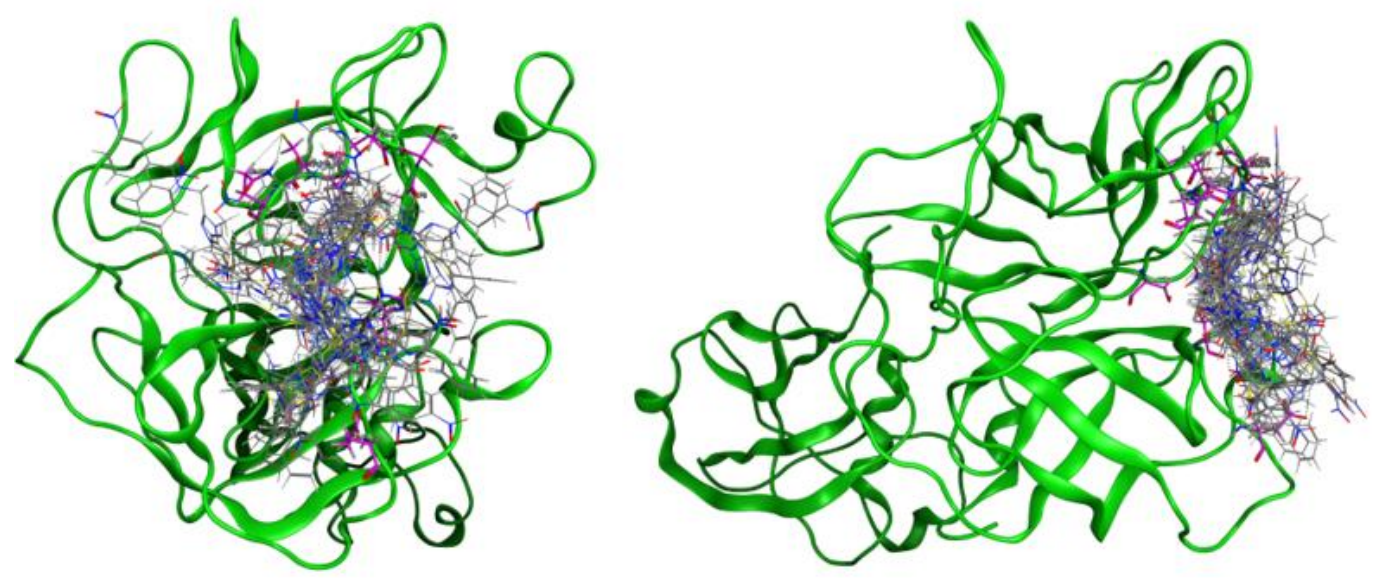

Figure S7. TMPRSS2 (Green) shows amino acids His296, Glu299, Asp435, Ser436, Cys437, Gln438, Ser441, Gly462, Ser463, and Gly464 (Pink) as region chosen for docking with 24 conformers of compound T7 (Gray).
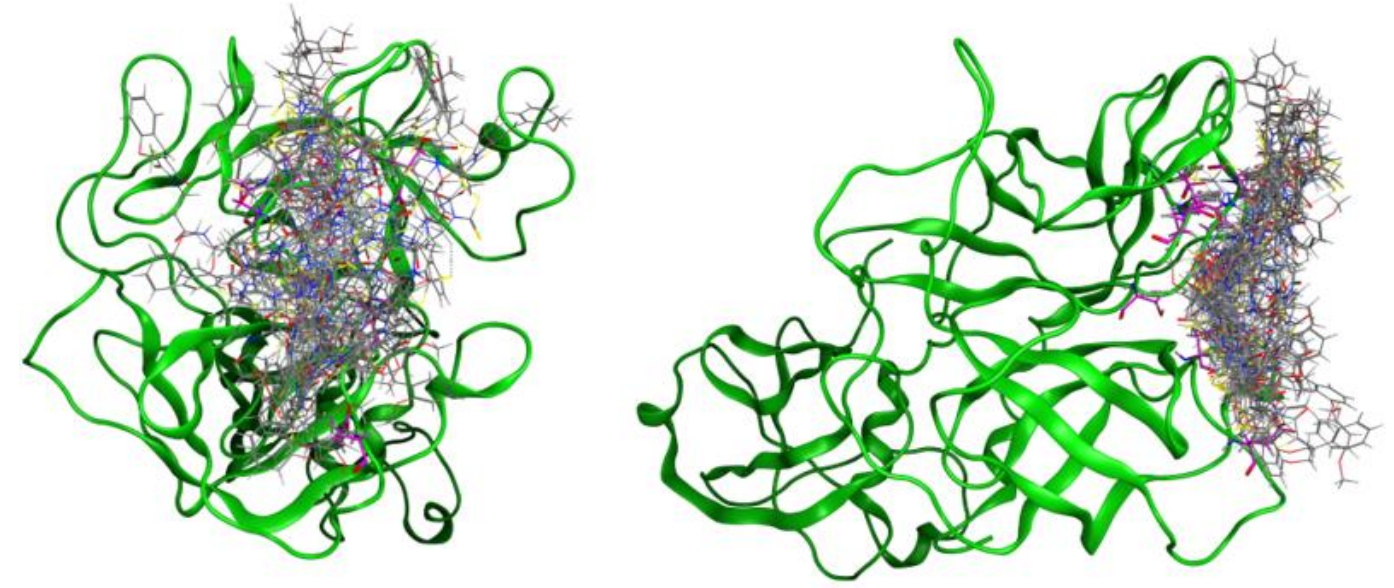

Figure S8. TMPRSS2 (Green) shows amino acids His296, Glu299, Asp435, Ser436, Cys437, Gln438, Ser441, Gly462, Ser463, and Gly464 (Pink) as region chosen for docking with 26 conformers of compound T8 (Gray).
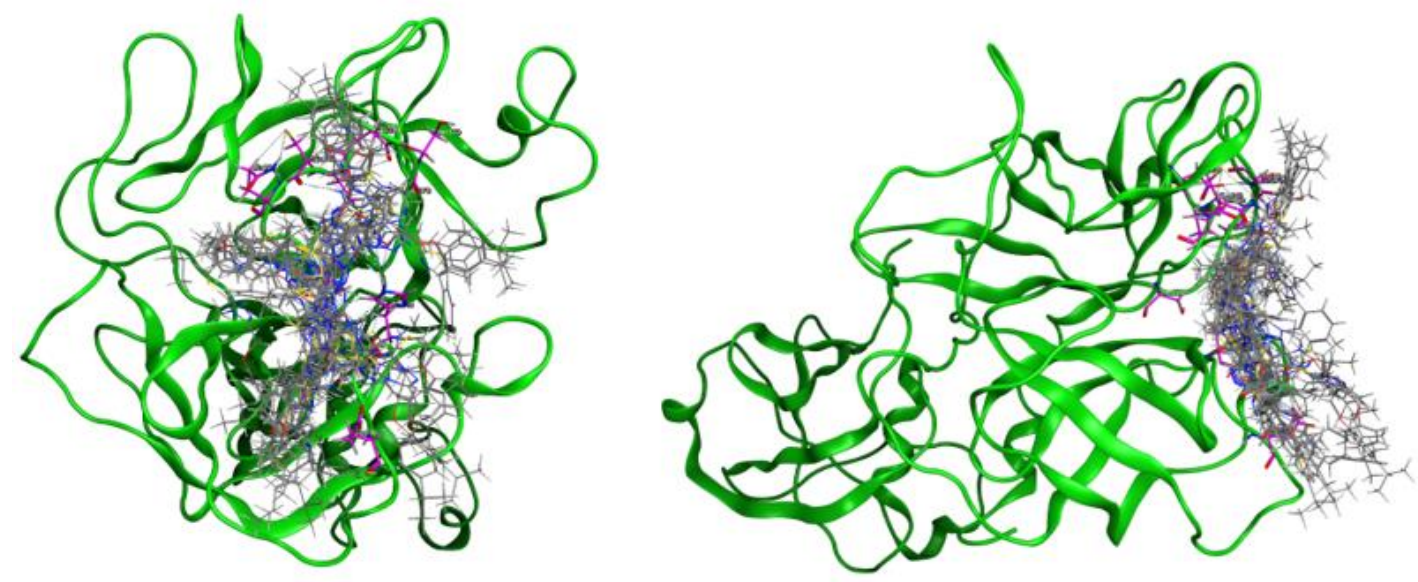

Figure S9. TMPRSS2 (Green) shows amino acids His296, Glu299, Asp435, Ser436, Cys437, Gln438, Ser441, Gly462, Ser463, and Gly464 (Pink) as region chosen for docking with 27 conformers of compound T9 (Gray). 

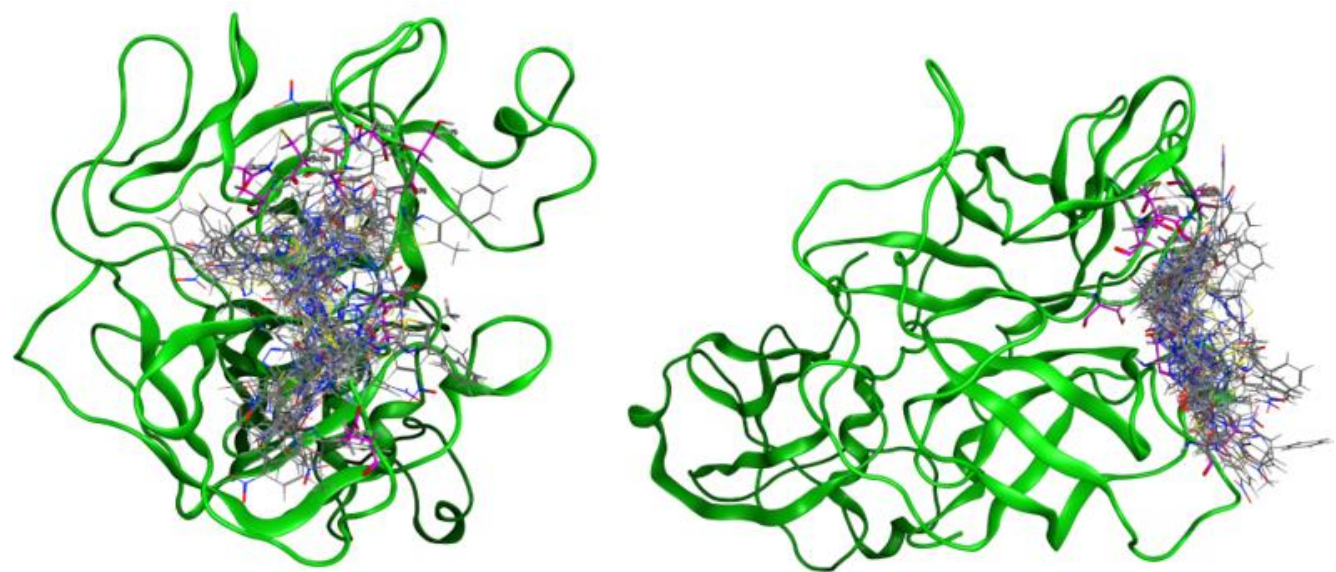

Figure S10. TMPRSS2 (Green) shows amino acids His296, Glu299, Asp435, Ser436, Cys437, Gln438, Ser441, Gly462, Ser463, and Gly464 (Pink) as region chosen for docking with 27 conformers of compound T10 (Gray).
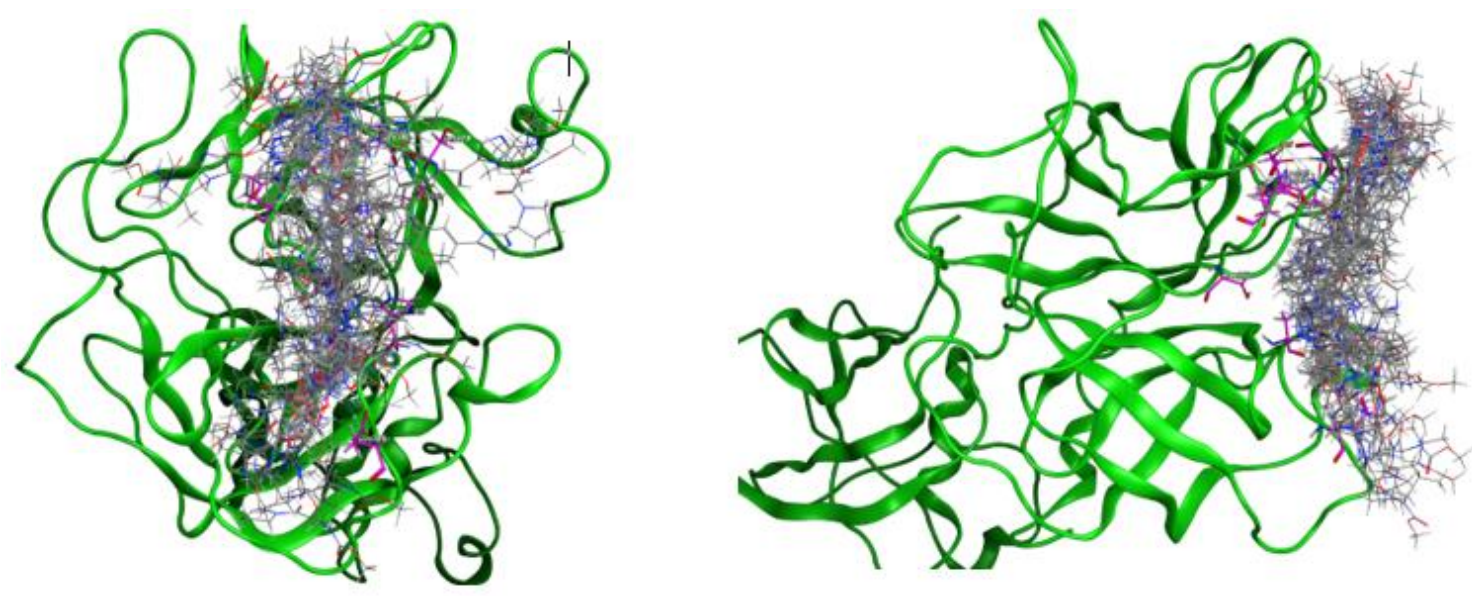

Figure S11. TMPRSS2 (Green) shows amino acids His296, Glu299, Asp435, Ser436, Cys437, Gln438, Ser441, Gly462, Ser463, and Gly464 (Pink) as region chosen for docking with 25 conformers of Daclatasvir (Gray).
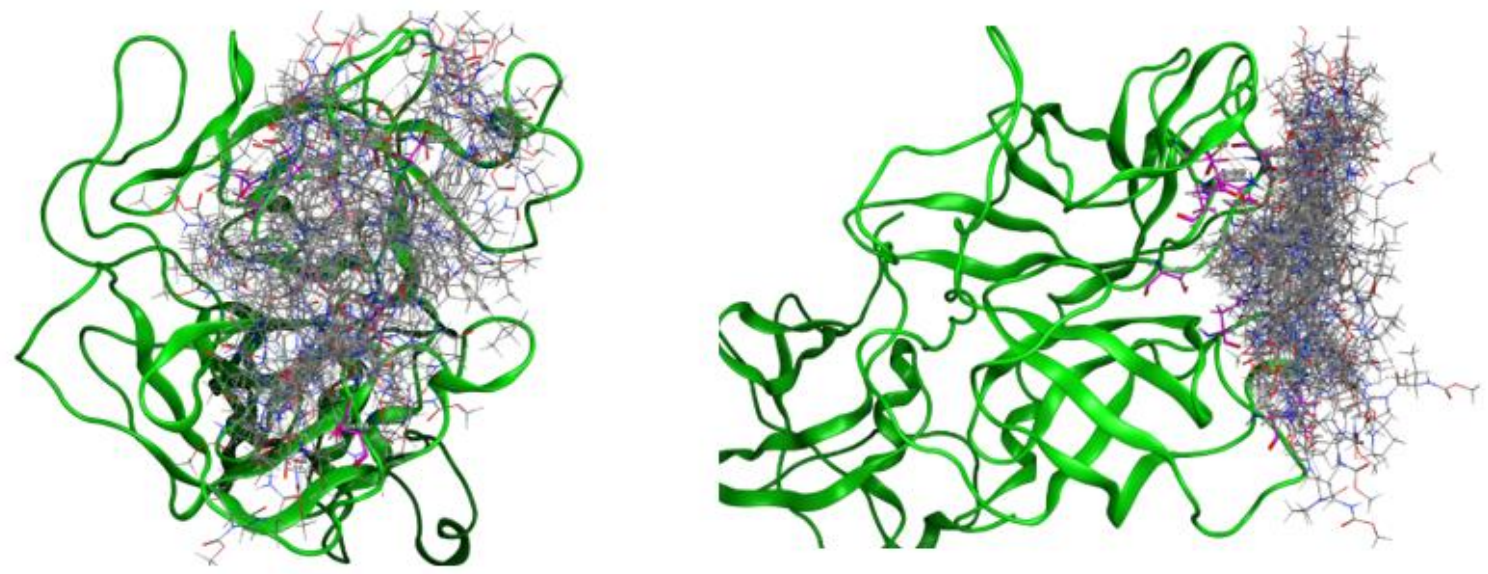

Figure S12. TMPRSS2 (Green) shows amino acids His296, Glu299, Asp435, Ser436, Cys437, Gln438, Ser441, Gly462, Ser463, and Gly464 (Pink) as region chosen for docking with 30 conformers of compound Ombitasvir (Gray). 

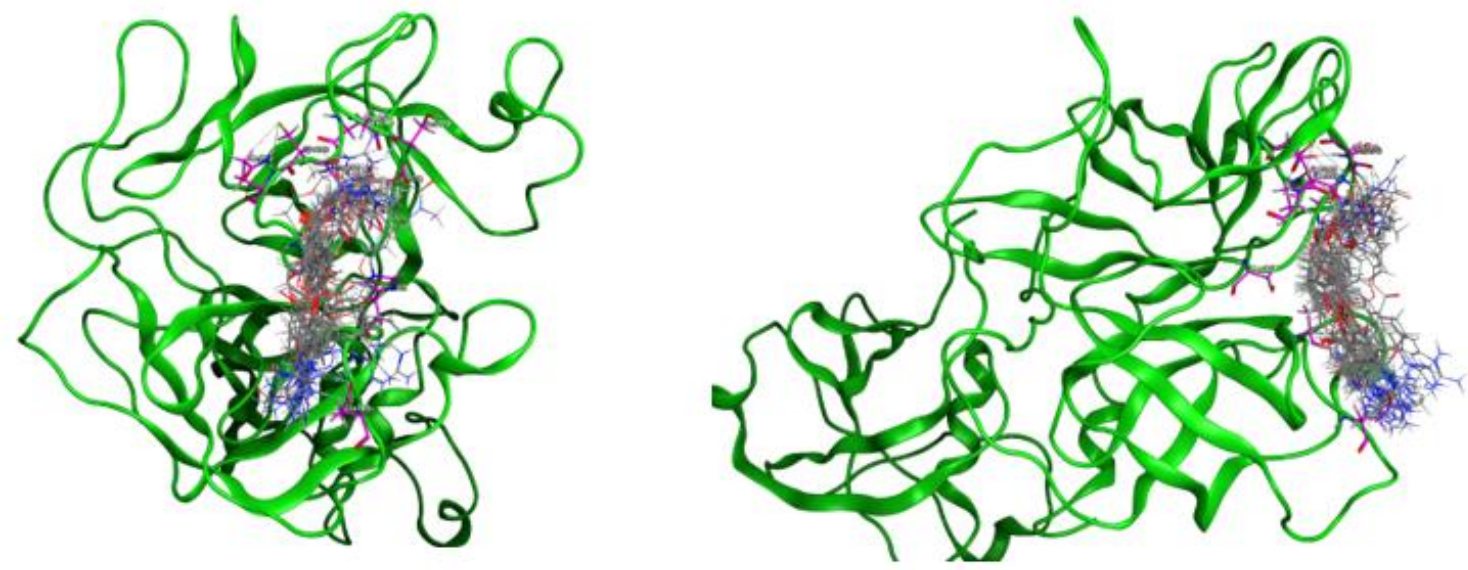

Figure S13. TMPRSS2 (Green) shows amino acids His296, Glu299, Asp435, Ser436, Cys437, Gln438, Ser441, Gly462, Ser463, and Gly464 (Pink) as region chosen for docking with 24 conformers of Camostat (Gray).
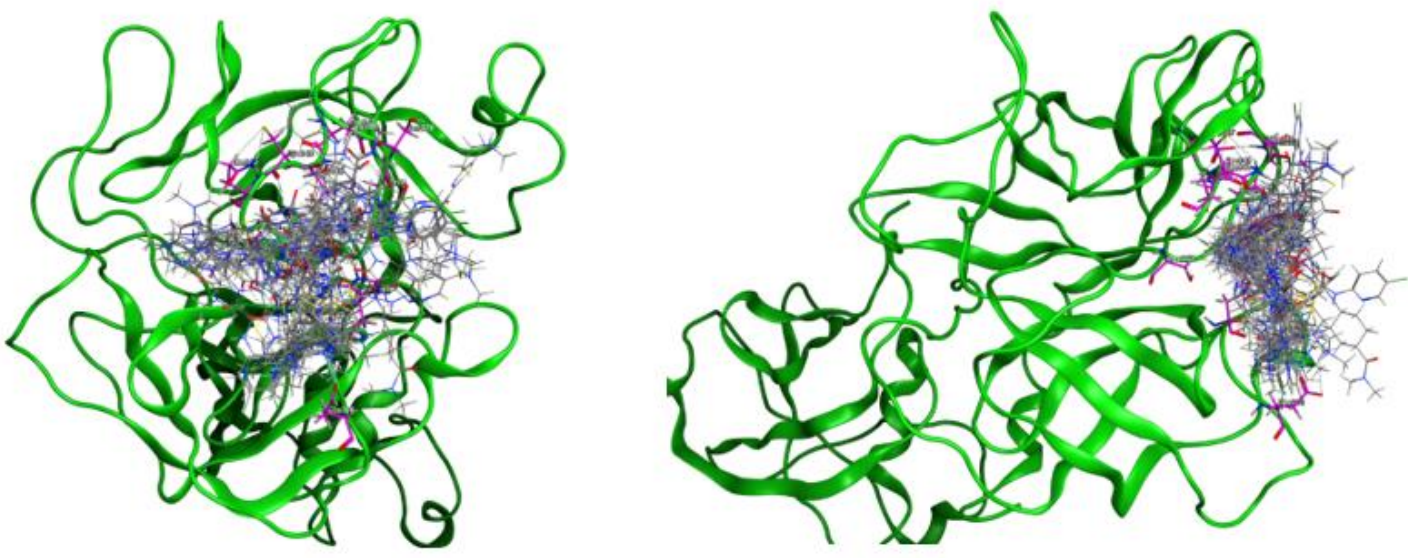

Figure S14. TMPRSS2 (Green) shows amino acids His296, Glu299, Asp435, Ser436, Cys437, Gln438, Ser441, Gly462, Ser463, and Gly464 (Pink) as region chosen for docking with 26 conformers of Edoxaban (Gray).
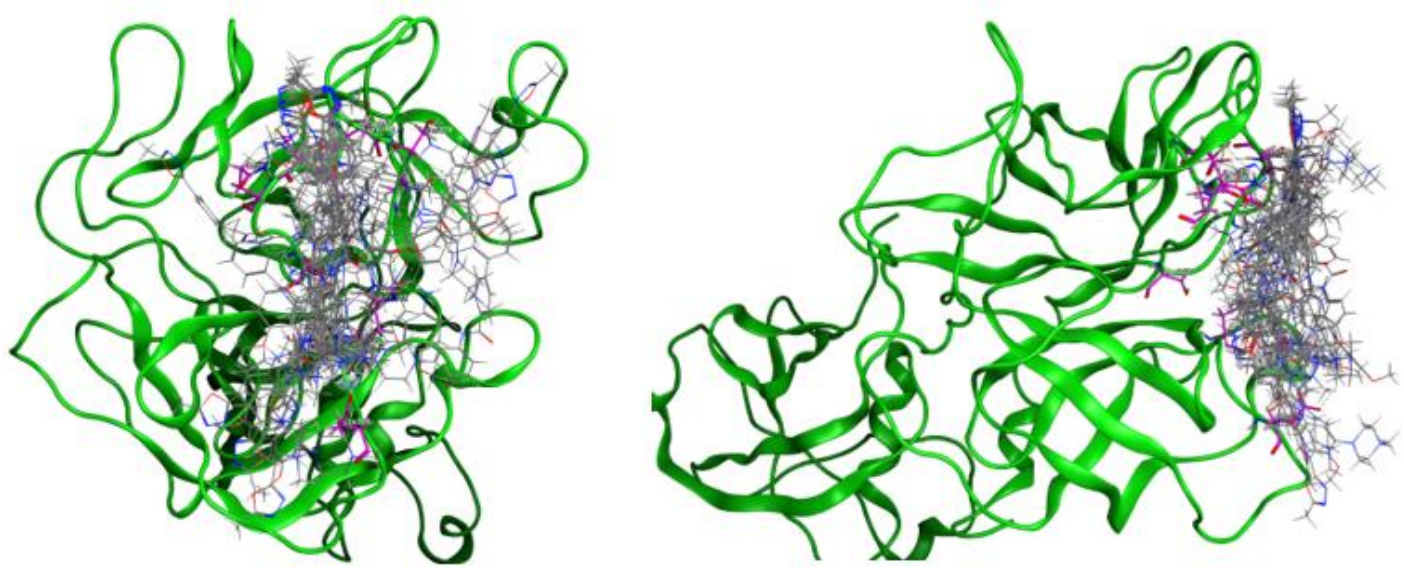

Figure S15. TMPRSS2 (Green) shows amino acids His296, Glu299, Asp435, Ser436, Cys437, Gln438, Ser441, Gly462, Ser463, and Gly464 (Pink) as region chosen for docking with 25 conformers of compound NCGC00386477 (Gray). 

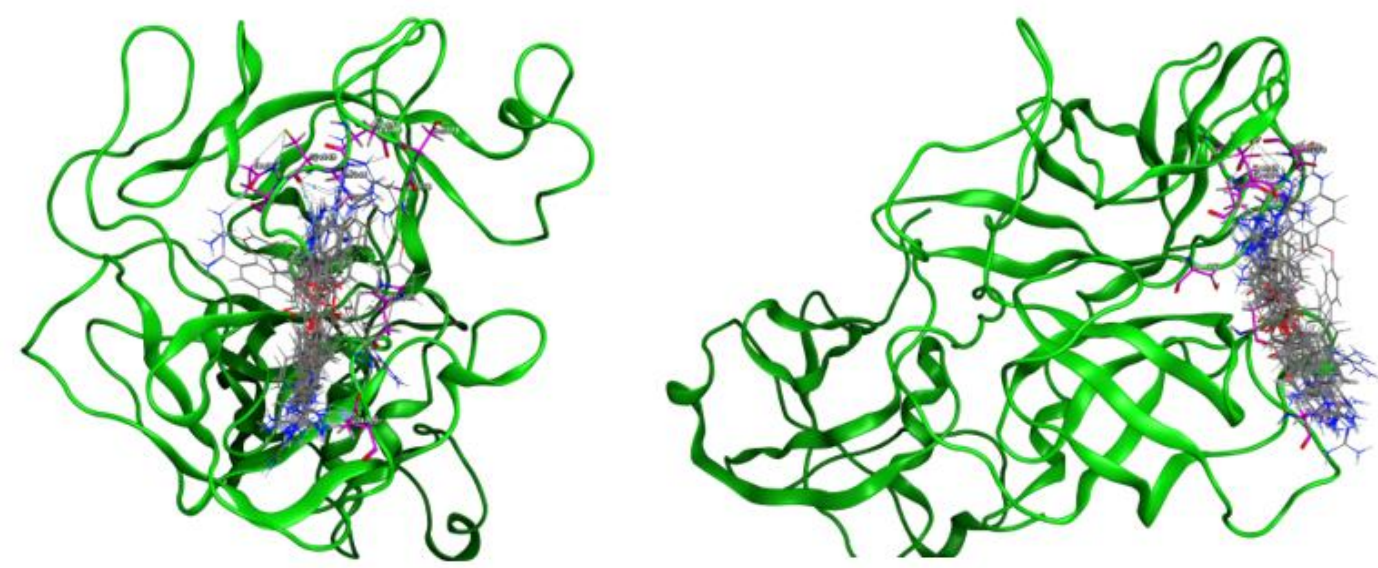

Figure S16. TMPRSS2 (Green) shows amino acids His296, Glu299, Asp435, Ser436, Cys437, Gln438, Ser441, Gly462, Ser463, and Gly464 (Pink) as region chosen for docking with 23 conformers of Nafamostat (Gray).
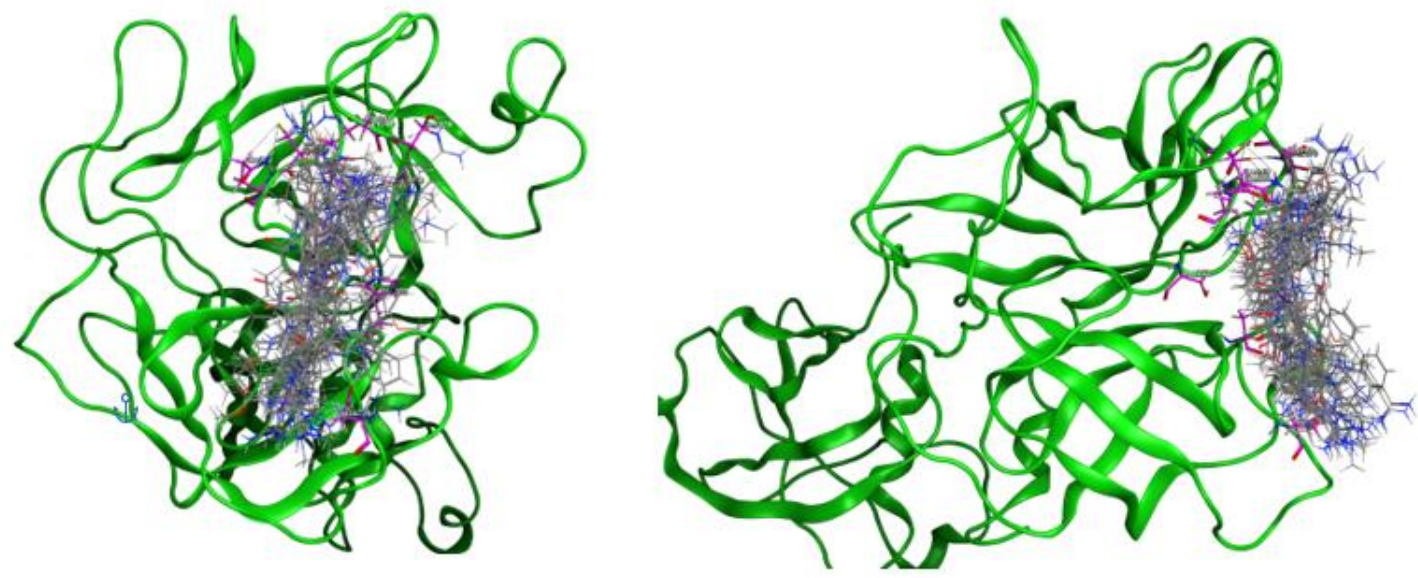

Figure S17. TMPRSS2 (Green) shows amino acids His296, Glu299, Asp435, Ser436, Cys437, Gln438, Ser441, Gly462, Ser463, and Gly464 (Pink) as region chosen for docking with 26 conformers of compound NCGC00386945 (Gray).
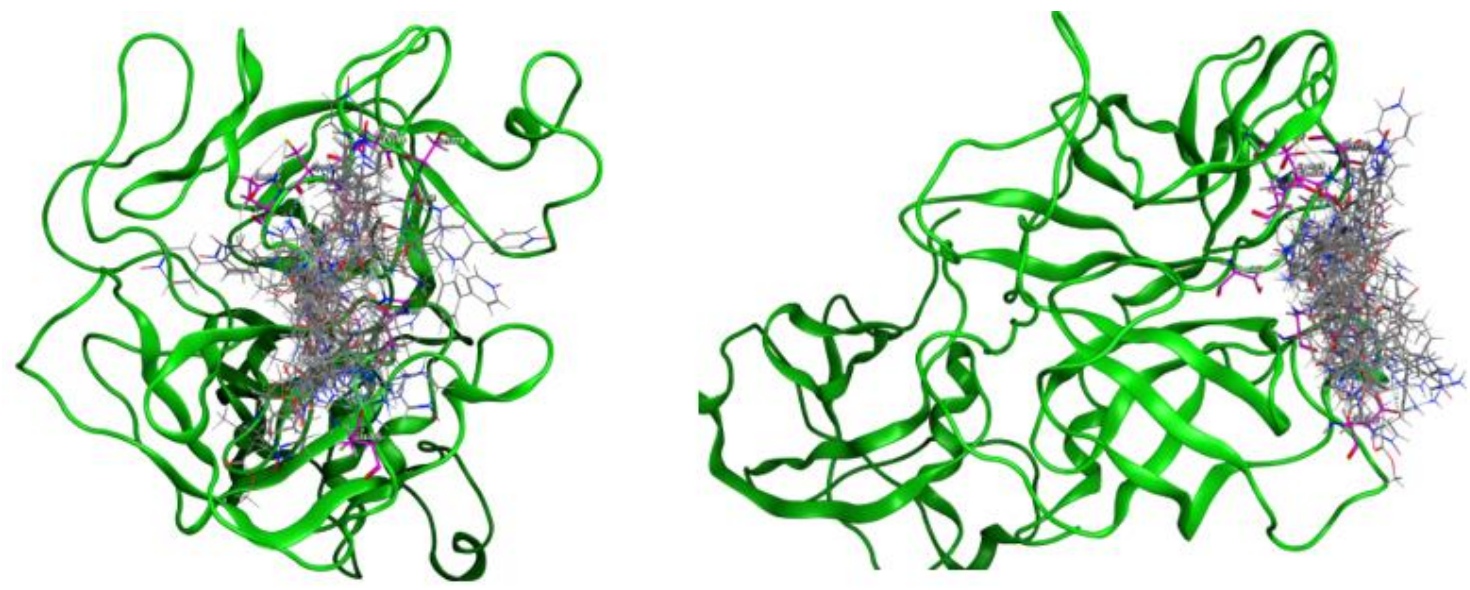

Figure S18. TMPRSS2 (Green) shows amino acids His296, Glu299, Asp435, Ser436, Cys437, Gln438, Ser441, Gly462, Ser463, and Gly464 (Pink) as region chosen for docking with 26 conformers of Otamixaban (Gray). 

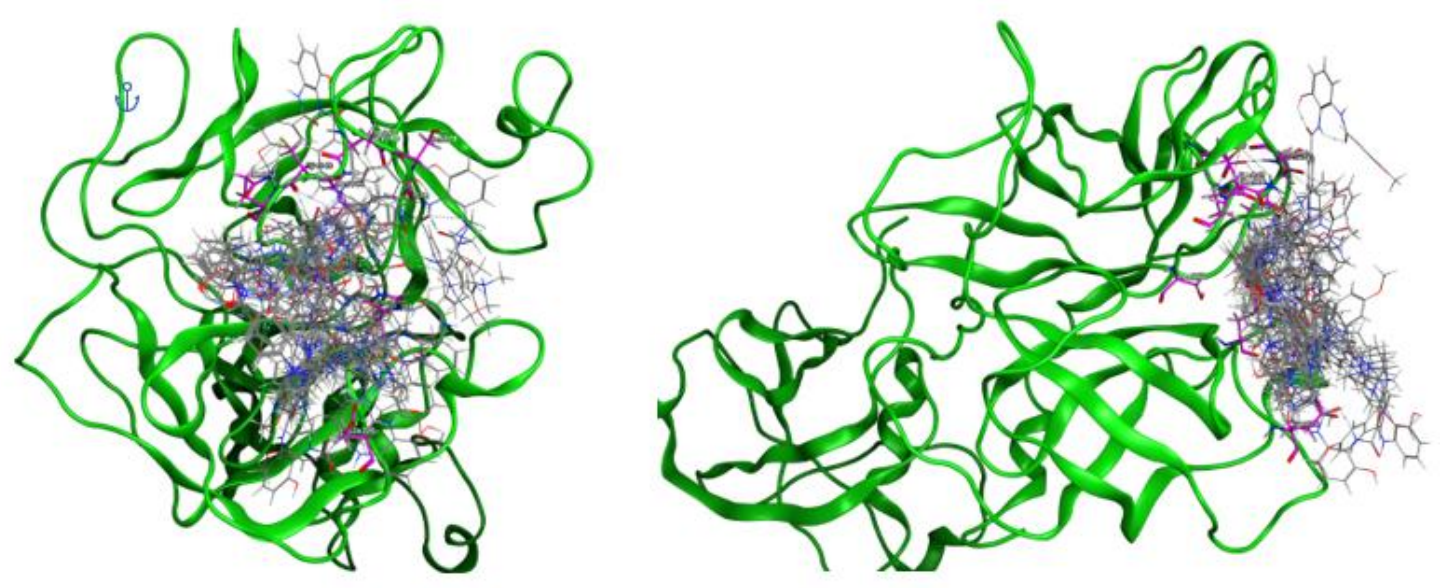

Figure S19. TMPRSS2 (Green) shows amino acids His296, Glu299, Asp435, Ser436, Cys437, Gln438, Ser441, Gly462, Ser463, and Gly464 (Pink) as region chosen for docking with 26 conformers of Darexaban (Gray).
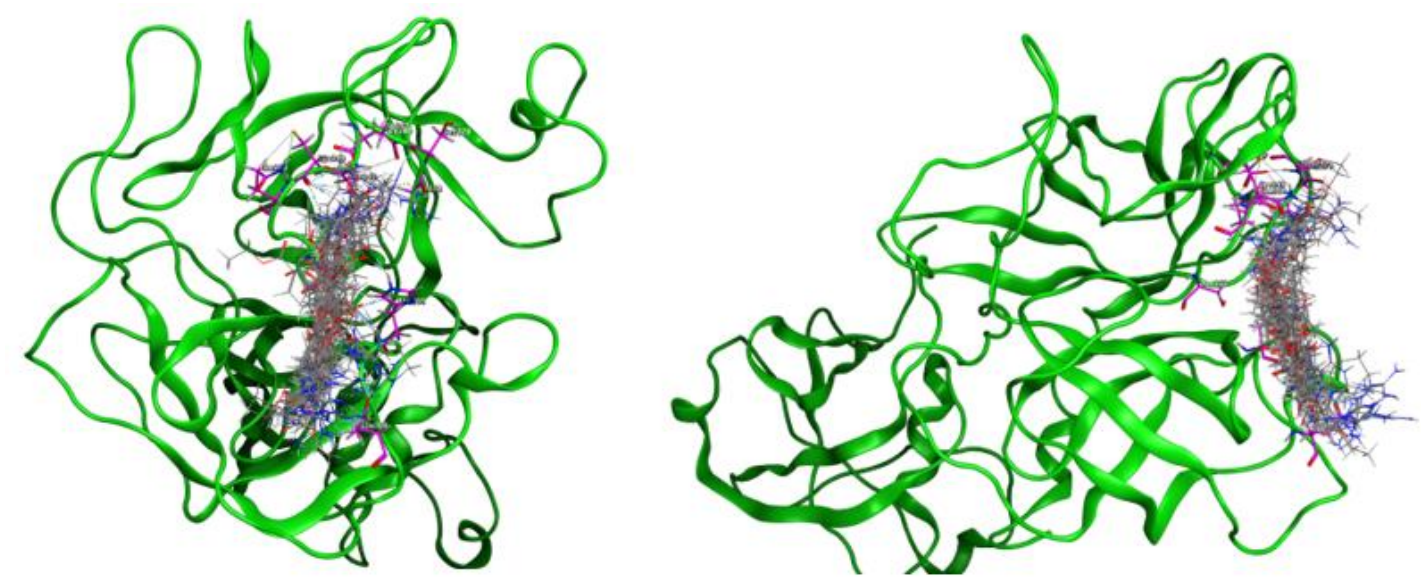

Figure S20. TMPRSS2 (Green) shows amino acids His296, Glu299, Asp435, Ser436, Cys437, Gln438, Ser441, Gly462, Ser463, and Gly464 (Pink) as region chosen for docking with 29 conformers of Gabexate (Gray).
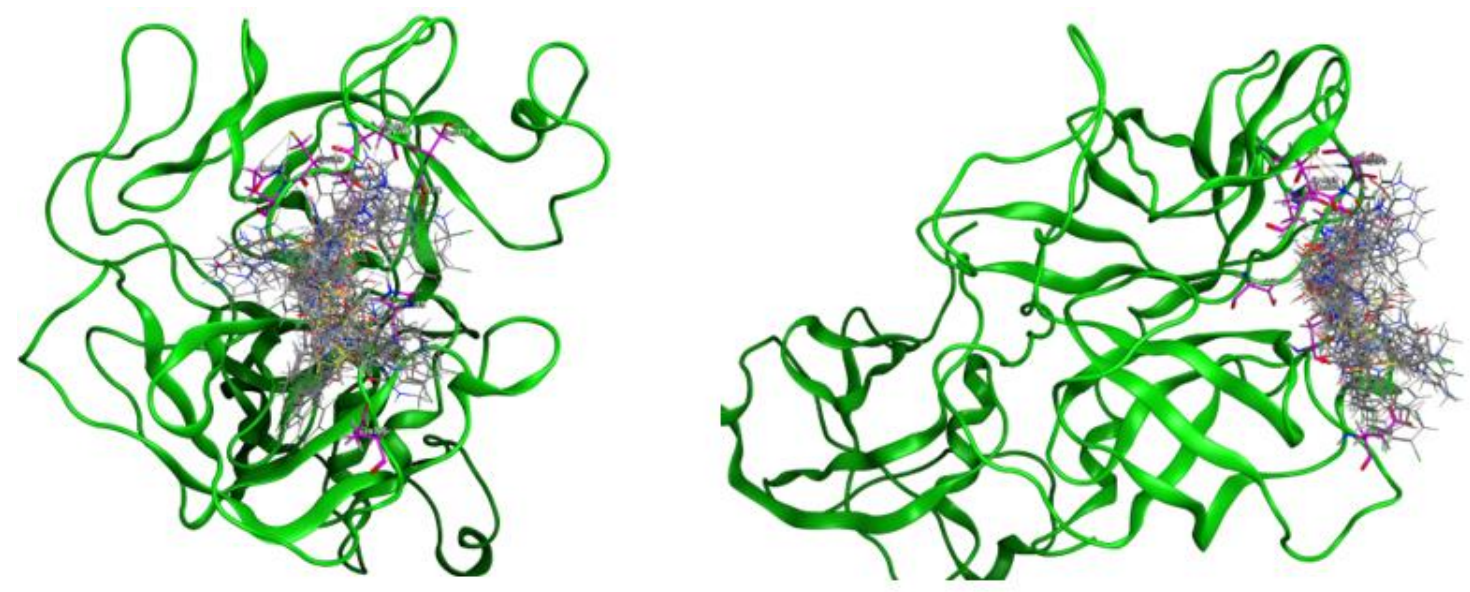

Figure S21. TMPRSS2 (Green) shows amino acids His296, Glu299, Asp435, Ser436, Cys437, Gln438, Ser441, Gly462, Ser463, and Gly464 (Pink) as region chosen for docking with 26 conformers of Letaxaban (Gray). 

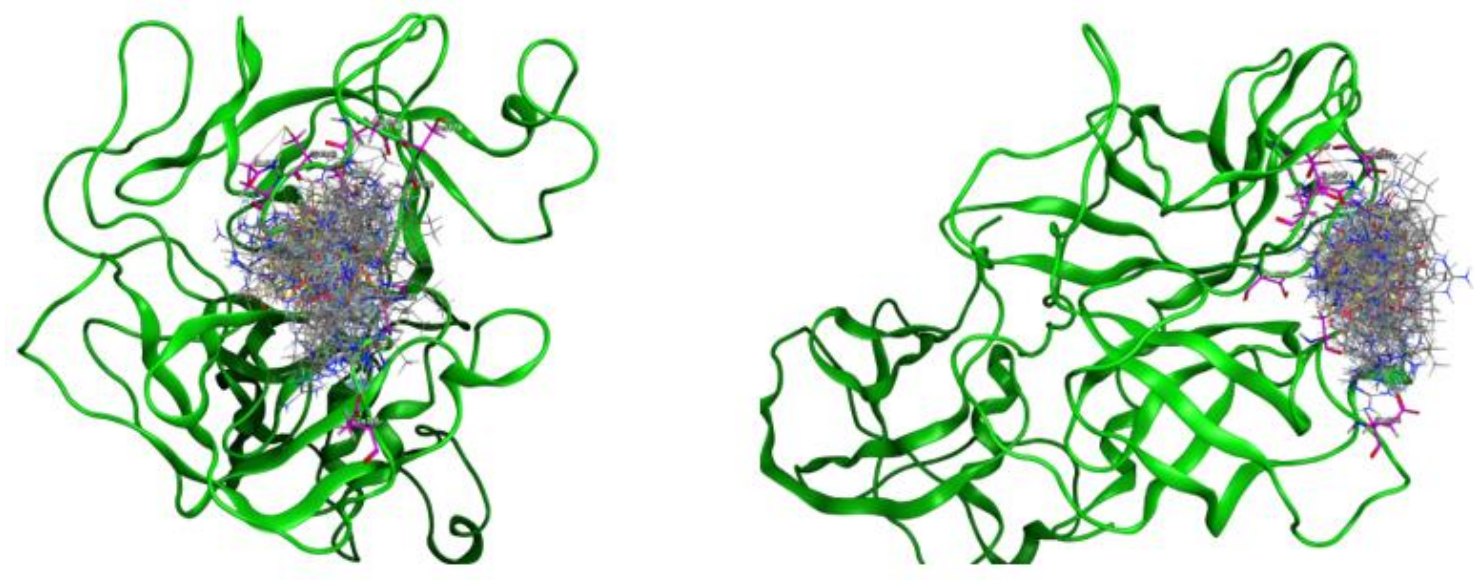

Figure S22. TMPRSS2 (Green) shows amino acids His296, Glu299, Asp435, Ser436, Cys437, Gln438, Ser441, Gly462, Ser463, and Gly464 (Pink) as region chosen for docking with 29 conformers of Argatroban (Gray).
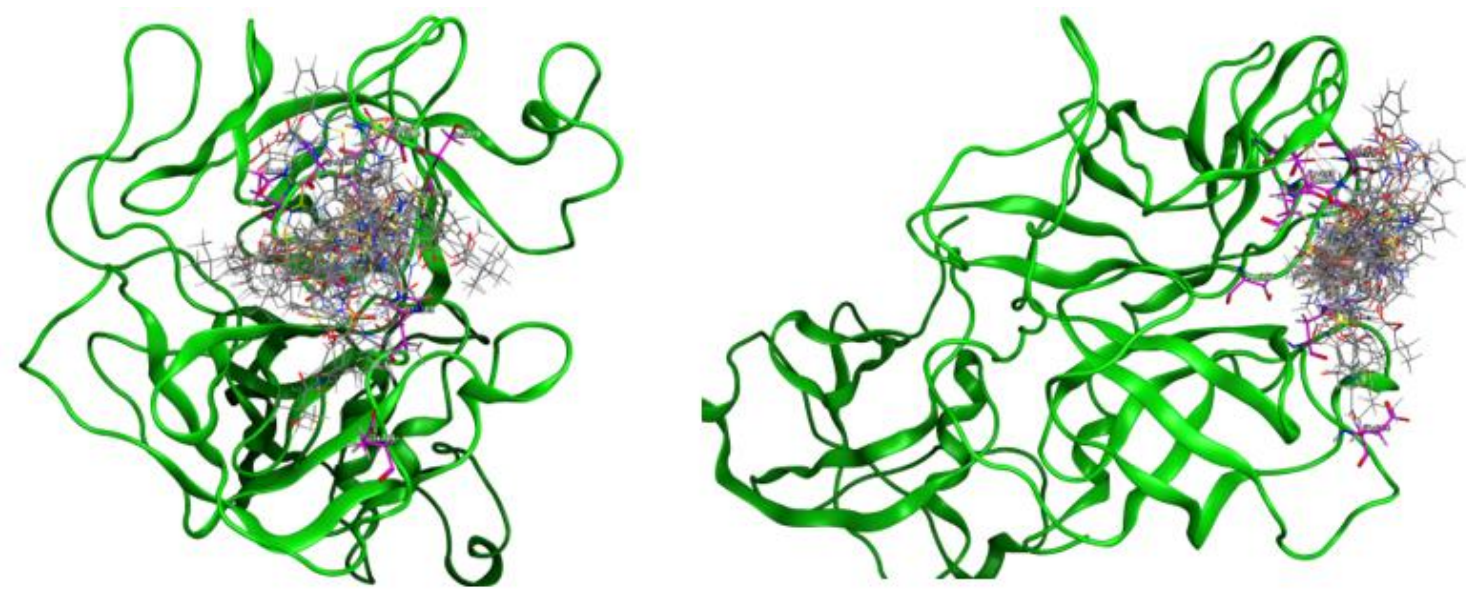

Figure S23. TMPRSS2 (Green) shows amino acids His296, Glu299, Asp435, Ser436, Cys437, Gln438, Ser441, Gly462, Ser463, and Gly464 (Pink) as region chosen for docking with 26 conformers of Sivelestat (Gray).
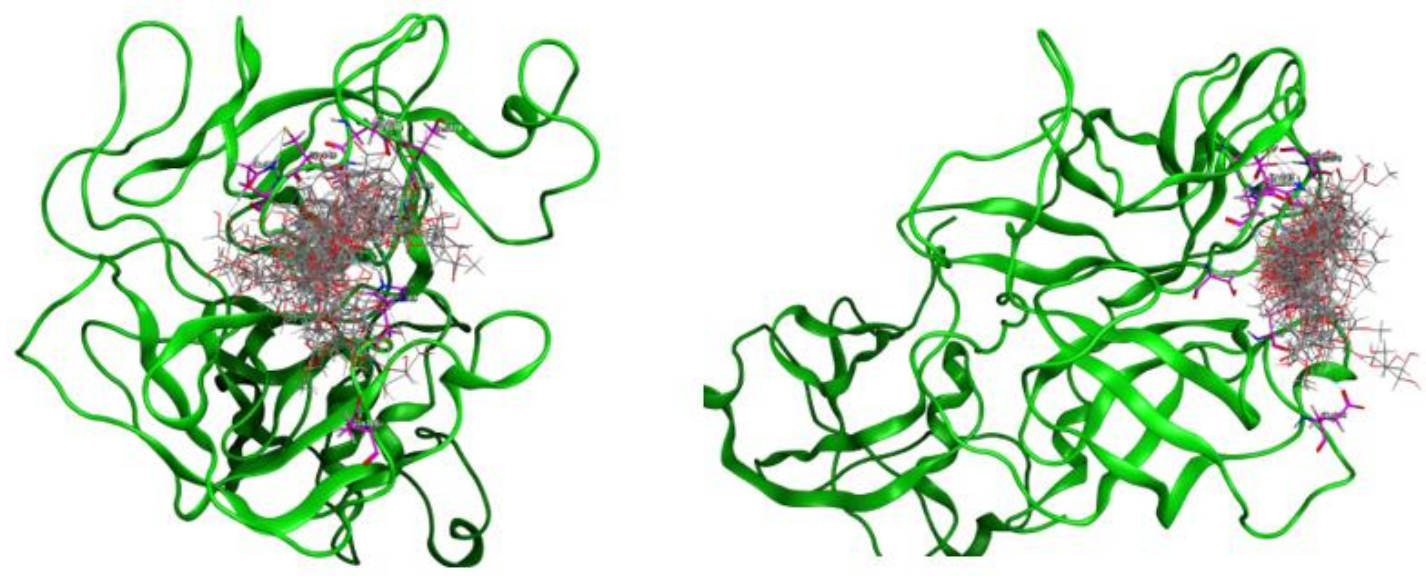

Figure S24. TMPRSS2 (Green) shows amino acids His296, Glu299, Asp435, Ser436, Cys437, Gln438, Ser441, Gly462, Ser463, and Gly464 (Pink) as region chosen for docking with 30 conformers of compound NCGC00385043 (Gray). 

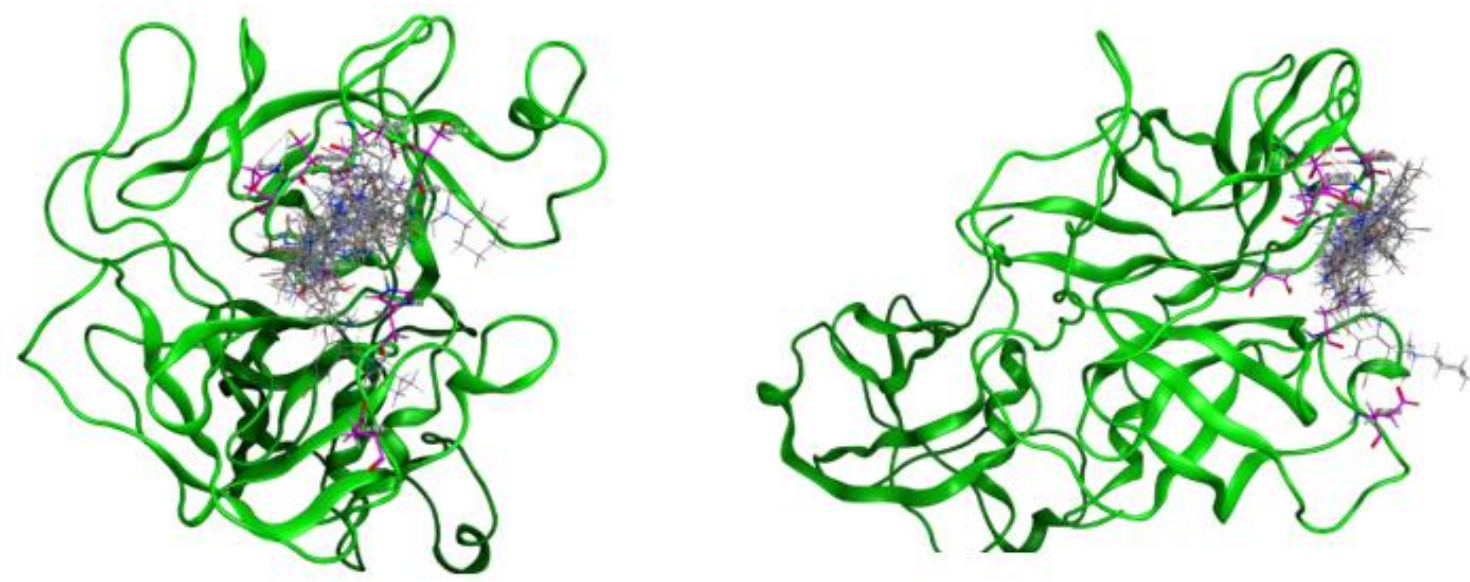

Figure S25. TMPRSS2 (Green) shows amino acids His296, Glu299, Asp435, Ser436, Cys437, Gln438, Ser441, Gly462, Ser463, and Gly464 (Pink) as region chosen for docking with 21 conformers of Bromhexine (Gray).

Table S1. $\Delta$ Gbinding of 21 to 30 conformers from each compound, average $\Delta$ Gbinding and SD.

\begin{tabular}{|c|c|c|}
\hline Compound & Conformer & $\Delta$ Gbinding \\
\hline T1 & 1 & -10.003396 \\
\hline T1 & 2 & -9.5028162 \\
\hline T1 & 3 & -9.3816652 \\
\hline T1 & 4 & -9.2959499 \\
\hline T1 & 5 & -9.2790861 \\
\hline T1 & 6 & -9.0783291 \\
\hline T1 & 7 & -9.0753641 \\
\hline T1 & 8 & -8.7984352 \\
\hline T1 & 9 & -8.6334057 \\
\hline T1 & 10 & -8.4404917 \\
\hline T1 & 11 & -8.3888254 \\
\hline T1 & 12 & -8.3585405 \\
\hline T1 & 13 & -8.3155022 \\
\hline T1 & 14 & -8.0704679 \\
\hline T1 & 15 & -7.9481745 \\
\hline T1 & 16 & -7.8926687 \\
\hline T1 & 17 & -7.8705177 \\
\hline T1 & 18 & -7.8615508 \\
\hline T1 & 19 & -7.8328905 \\
\hline T1 & 20 & -7.7946715 \\
\hline T1 & 21 & -7.6466455 \\
\hline T1 & 22 & -7.5944762 \\
\hline T1 & 23 & -7.467999 \\
\hline T1 & 24 & -7.4473333 \\
\hline T1 & 25 & -7.3843675 \\
\hline T1 & 26 & -7.3234034 \\
\hline T1 & 27 & -7.2930708 \\
\hline T1 & 28 & -7.1270895 \\
\hline \multirow[t]{3}{*}{ T1 } & 29 & -6.5075951 \\
\hline & Average $\Delta \mathrm{G}_{\text {binding }}$ & -8.19361135 \\
\hline & SD & 0.83814171 \\
\hline T2 & 1 & -10.022358 \\
\hline T2 & 2 & -9.6339903 \\
\hline T2 & 3 & -9.5879698 \\
\hline $\mathbf{T 2}$ & 4 & -9.0783129 \\
\hline T2 & 5 & -8.8606043 \\
\hline T2 & 6 & -8.7780361 \\
\hline T2 & 7 & -8.7608776 \\
\hline T2 & 8 & -8.6921701 \\
\hline T2 & 9 & -8.5939379 \\
\hline $\mathrm{T} 2$ & 10 & -8.5521517 \\
\hline T2 & 11 & -8.3879843 \\
\hline
\end{tabular}




\begin{tabular}{|c|c|c|}
\hline Compound & Conformer & $\Delta$ Gbinding \\
\hline $\mathbf{T} 2$ & 12 & -8.245903 \\
\hline $\mathbf{T 2}$ & 13 & -8.0666447 \\
\hline $\mathbf{T 2}$ & 14 & -8.0059614 \\
\hline $\mathbf{T 2}$ & 15 & -7.7485528 \\
\hline $\mathbf{T 2}$ & 16 & -7.7424426 \\
\hline $\mathbf{T 2}$ & 17 & -7.7311025 \\
\hline $\mathbf{T 2}$ & 18 & -7.699697 \\
\hline $\mathbf{T 2}$ & 19 & -7.5649576 \\
\hline T2 & 20 & -7.5632124 \\
\hline T2 & 21 & -7.5493693 \\
\hline $\mathbf{T 2}$ & 22 & -7.4882078 \\
\hline $\mathbf{T 2}$ & 23 & -7.4084682 \\
\hline $\mathbf{T 2}$ & 24 & -7.0118942 \\
\hline $\mathbf{T 2}$ & 25 & -6.9634185 \\
\hline $\mathbf{T 2}$ & 26 & -6.6150498 \\
\hline \multirow[t]{3}{*}{$\mathbf{T 2}$} & 27 & -6.3929582 \\
\hline & Average $\Delta \mathrm{G}_{\text {binding }}$ & -8.10171233 \\
\hline & SD & 0.90894255 \\
\hline T3 & 1 & -9.0872488 \\
\hline T3 & 2 & -9.0801687 \\
\hline T3 & 3 & -9.0403929 \\
\hline T3 & 4 & -8.9255257 \\
\hline T3 & 5 & -8.9209614 \\
\hline T3 & 6 & -8.6274405 \\
\hline T3 & 7 & -8.6184263 \\
\hline T3 & 8 & -8.5198822 \\
\hline T3 & 9 & -8.322113 \\
\hline T3 & 10 & -8.315093 \\
\hline T3 & 11 & -8.3098307 \\
\hline T3 & 12 & -8.1798973 \\
\hline T3 & 13 & -8.0936956 \\
\hline T3 & 14 & -8.0496025 \\
\hline T3 & 15 & -7.8540268 \\
\hline T3 & 16 & -7.744885 \\
\hline T3 & 17 & -7.7321877 \\
\hline T3 & 18 & -7.6184058 \\
\hline T3 & 19 & -7.4833121 \\
\hline T3 & 20 & -7.4545417 \\
\hline T3 & 21 & -7.3769569 \\
\hline T3 & 22 & -7.3355923 \\
\hline T3 & 23 & -7.296454 \\
\hline T3 & 24 & -7.1494551 \\
\hline T3 & 25 & -7.1465697 \\
\hline T3 & 26 & -7.1312723 \\
\hline \multirow[t]{3}{*}{ T3 } & 27 & -6.8732405 \\
\hline & Average $\Delta \mathrm{G}_{\text {binding }}$ & -8.01063624 \\
\hline & SD & 0.68474912 \\
\hline T4 & 1 & -9.2188988 \\
\hline T4 & 2 & -8.6898699 \\
\hline T4 & 3 & -8.5985565 \\
\hline T4 & 4 & -8.5929041 \\
\hline T4 & 5 & -8.50595 \\
\hline T4 & 6 & -8.3943624 \\
\hline T4 & 7 & -8.380353 \\
\hline T4 & 8 & -8.3689556 \\
\hline T4 & 9 & -8.3514271 \\
\hline T4 & 10 & -8.3018761 \\
\hline T4 & 11 & -8.2238884 \\
\hline T4 & 12 & -8.2036352 \\
\hline T4 & 13 & -8.1405926 \\
\hline T4 & 14 & -8.0946236 \\
\hline T4 & 15 & -8.089736 \\
\hline T4 & 16 & -8.0655165 \\
\hline T4 & 17 & -8.0641956 \\
\hline
\end{tabular}




\begin{tabular}{|c|c|c|}
\hline Compound & Conformer & $\Delta$ Gbinding \\
\hline T4 & 18 & -8.0602865 \\
\hline T4 & 19 & -7.9969692 \\
\hline T4 & 20 & -7.9864345 \\
\hline T4 & 21 & -7.8847065 \\
\hline T4 & 22 & -7.8003235 \\
\hline T4 & 23 & -7.7165313 \\
\hline T4 & 24 & -7.6500716 \\
\hline T4 & 25 & -7.5624533 \\
\hline T4 & 26 & -7.510438 \\
\hline T4 & 27 & -7.3479362 \\
\hline T4 & 28 & -7.0788541 \\
\hline T4 & 29 & -6.7855134 \\
\hline \multirow[t]{3}{*}{ T4 } & 30 & -6.2144074 \\
\hline & Average $\Delta \mathrm{G}_{\text {binding }}$ & -7.9960089 \\
\hline & SD & 0.59719471 \\
\hline T5 & 1 & -8.8463116 \\
\hline T5 & 2 & -8.7761745 \\
\hline T5 & 3 & -8.7601585 \\
\hline T5 & 4 & -8.7128248 \\
\hline T5 & 5 & -8.6061783 \\
\hline T5 & 6 & -8.4604912 \\
\hline T5 & 7 & -8.4060631 \\
\hline T5 & 8 & -8.2876902 \\
\hline T5 & 9 & -8.2334681 \\
\hline T5 & 10 & -8.2237606 \\
\hline T5 & 11 & -8.1152878 \\
\hline T5 & 12 & -8.1035748 \\
\hline T5 & 13 & -8.0933323 \\
\hline T5 & 14 & -8.0835581 \\
\hline T5 & 15 & -8.0639343 \\
\hline T5 & 16 & -8.0269032 \\
\hline T5 & 17 & -8.0209751 \\
\hline T5 & 18 & -7.9286127 \\
\hline T5 & 19 & -7.9155855 \\
\hline T5 & 20 & -7.9118838 \\
\hline T5 & 21 & -7.816483 \\
\hline T5 & $\frac{11}{22}$ & -7.6477575 \\
\hline T5 & 23 & -7.6306605 \\
\hline T5 & 24 & -7.2972651 \\
\hline T5 & 25 & -7.2300811 \\
\hline T5 & 26 & -7.2121 \\
\hline T5 & 27 & -6.7440133 \\
\hline \multirow[t]{3}{*}{ T5 } & 28 & -6.7035975 \\
\hline & Average $\Delta \mathrm{G}_{\text {binding }}$ & -7.99495452 \\
\hline & SD & 0.56635107 \\
\hline T6 & 1 & -9.3085299 \\
\hline T6 & 2 & -9.0219545 \\
\hline T6 & 3 & -8.9738646 \\
\hline T6 & 4 & -8.9567413 \\
\hline T6 & 5 & -8.7691965 \\
\hline T6 & 6 & -8.6345243 \\
\hline T6 & 7 & -8.4675426 \\
\hline T6 & 8 & -8.4069319 \\
\hline T6 & 9 & -8.3941784 \\
\hline T6 & 10 & -8.3859043 \\
\hline T6 & 11 & -8.2488203 \\
\hline T6 & 12 & -8.2265368 \\
\hline T6 & 13 & -8.1576548 \\
\hline T6 & 14 & -8.1375952 \\
\hline T6 & 15 & -8.1242628 \\
\hline T6 & 16 & -8.0387306 \\
\hline T6 & 17 & -8.0217066 \\
\hline T6 & 18 & -7.975193 \\
\hline T6 & 19 & -7.8419881 \\
\hline
\end{tabular}




\begin{tabular}{|c|c|c|}
\hline Compound & Conformer & $\Delta$ Gbinding \\
\hline T6 & 20 & -7.8149767 \\
\hline T6 & 21 & -7.5745993 \\
\hline T6 & 22 & -7.4310431 \\
\hline T6 & 23 & -6.9749837 \\
\hline T6 & 24 & -6.6369896 \\
\hline T6 & 25 & -6.6182857 \\
\hline T6 & 26 & -6.4696603 \\
\hline \multirow[t]{3}{*}{ T6 } & 27 & -6.2355638 \\
\hline & Average $\Delta \mathrm{G}_{\text {binding }}$ & -7.99436884 \\
\hline & SD & 0.81604143 \\
\hline T7 & 1 & -9.2756252 \\
\hline T7 & 2 & -8.9142857 \\
\hline T7 & 3 & -8.9017849 \\
\hline T7 & 4 & -8.7062016 \\
\hline T7 & 5 & -8.6486025 \\
\hline T7 & 6 & -8.647892 \\
\hline T7 & 7 & -8.5693331 \\
\hline T7 & 8 & -8.5575619 \\
\hline T7 & 9 & -8.5386095 \\
\hline T7 & 10 & -8.5009775 \\
\hline $\mathbf{T 7}$ & 11 & -8.4386635 \\
\hline T7 & 12 & -8.4243889 \\
\hline T7 & 13 & -8.3803549 \\
\hline T7 & 14 & -8.247942 \\
\hline T7 & 15 & -8.1754227 \\
\hline T7 & 16 & -8.0870533 \\
\hline T7 & 17 & -8.0591297 \\
\hline T7 & 18 & -7.7034016 \\
\hline T7 & 19 & -7.6054735 \\
\hline T7 & 20 & -7.5258908 \\
\hline T7 & 21 & -7.4642801 \\
\hline T7 & 22 & -7.3333788 \\
\hline T7 & 23 & -7.2554908 \\
\hline T7 & 24 & -7.2306013 \\
\hline T7 & 25 & -7.0912528 \\
\hline T7 & 26 & -6.6262579 \\
\hline T7 & 27 & -6.3153048 \\
\hline \multirow[t]{3}{*}{$\mathbf{T 7}$} & 28 & -6.1678081 \\
\hline & Average $\Delta \mathrm{G}_{\text {binding }}$ & -7.97832034 \\
\hline & SD & 0.80859149 \\
\hline T8 & 1 & -9.6677294 \\
\hline T8 & 2 & -9.0873976 \\
\hline T8 & 3 & -9.0046053 \\
\hline T8 & 4 & -8.8117313 \\
\hline T8 & 5 & -8.7953749 \\
\hline T8 & 6 & -8.7727785 \\
\hline T8 & 7 & -8.5950193 \\
\hline T8 & 8 & -8.4820747 \\
\hline T8 & 9 & -8.4754086 \\
\hline T8 & 10 & -8.3118105 \\
\hline T8 & 11 & -8.2353954 \\
\hline T8 & 12 & -8.2215805 \\
\hline T8 & 13 & -8.1239853 \\
\hline T8 & 14 & -8.0981016 \\
\hline T8 & 15 & -8.0912466 \\
\hline T8 & 16 & -8.0639839 \\
\hline T8 & 17 & -7.807765 \\
\hline T8 & 18 & -7.7613025 \\
\hline T8 & 19 & -7.7482762 \\
\hline T8 & 20 & -7.720624 \\
\hline T8 & 21 & -7.6101966 \\
\hline T8 & 22 & -7.3269901 \\
\hline T8 & 23 & -7.2866149 \\
\hline T8 & 24 & -7.2247896 \\
\hline
\end{tabular}




\begin{tabular}{|c|c|c|}
\hline Compound & Conformer & $\Delta$ Gbinding \\
\hline T8 & 25 & -7.2101569 \\
\hline T8 & 26 & -7.2000165 \\
\hline T8 & 27 & -7.19806 \\
\hline T8 & 28 & -7.0837798 \\
\hline T8 & 29 & -6.805882 \\
\hline \multirow[t]{3}{*}{ T8 } & 30 & -6.2772179 \\
\hline & Average $\Delta \mathrm{G}_{\text {binding }}$ & -7.96999651 \\
\hline & SD & 0.76511658 \\
\hline T9 & 1 & -8.9598265 \\
\hline T9 & 2 & -8.9550142 \\
\hline T9 & 3 & -8.921051 \\
\hline T9 & 4 & -8.7088957 \\
\hline T9 & 5 & -8.6447392 \\
\hline T9 & 6 & -8.5934811 \\
\hline T9 & 7 & -8.5755234 \\
\hline T9 & 8 & -8.5448742 \\
\hline T9 & 9 & -8.5338984 \\
\hline T9 & 10 & -8.4177952 \\
\hline T9 & 11 & -8.2045507 \\
\hline T9 & 12 & -8.1820631 \\
\hline T9 & 13 & -8.1658182 \\
\hline T9 & 14 & -8.1623573 \\
\hline T9 & 15 & -8.1459322 \\
\hline T9 & 16 & -8.135849 \\
\hline T9 & 17 & -8.0513248 \\
\hline T9 & 18 & -8.0358849 \\
\hline T9 & 19 & -7.972672 \\
\hline T9 & 20 & -7.9299703 \\
\hline T9 & 21 & -7.9112868 \\
\hline T9 & 22 & -7.684484 \\
\hline T9 & 23 & -6.969893 \\
\hline T9 & 24 & -6.8369207 \\
\hline T9 & 25 & -6.5765576 \\
\hline T9 & 26 & -6.5230303 \\
\hline T9 & 27 & -6.3880262 \\
\hline \multirow[t]{3}{*}{ T9 } & 28 & -6.1047964 \\
\hline & Average $\Delta G_{\text {binding }}$ & -7.95844701 \\
\hline & $\mathrm{SD}$ & 0.81850837 \\
\hline T10 & 1 & -9.3553381 \\
\hline T10 & 2 & -9.3253126 \\
\hline T10 & 3 & -9.2208309 \\
\hline T10 & 4 & -9.0547533 \\
\hline T10 & 5 & -8.9080944 \\
\hline T10 & 6 & -8.8517351 \\
\hline T10 & 7 & -8.5650959 \\
\hline T10 & 8 & -8.4860783 \\
\hline T10 & 9 & -8.4806604 \\
\hline T10 & 10 & -8.3173981 \\
\hline T10 & 11 & -8.2351208 \\
\hline T10 & 12 & -8.107399 \\
\hline T10 & 13 & -7.9825597 \\
\hline T10 & 14 & -7.9576359 \\
\hline T10 & 15 & -7.9544106 \\
\hline T10 & 16 & -7.8897438 \\
\hline T10 & 17 & -7.7604818 \\
\hline T10 & 18 & -7.7534285 \\
\hline T10 & 19 & -7.5839596 \\
\hline T10 & 20 & -7.583334 \\
\hline T10 & 21 & -7.5752831 \\
\hline T10 & 22 & -7.5171504 \\
\hline T10 & 23 & -7.3344922 \\
\hline T10 & 24 & -7.2096562 \\
\hline T10 & 25 & -7.1749067 \\
\hline T10 & 26 & -6.9748254 \\
\hline
\end{tabular}




\begin{tabular}{|c|c|c|}
\hline Compound & Conformer & $\Delta$ Gbinding \\
\hline T10 & 27 & -6.5297976 \\
\hline T10 & 28 & -6.4548984 \\
\hline \multirow[t]{3}{*}{ T10 } & 29 & -6.2984314 \\
\hline & Average $\Delta \mathrm{G}_{\text {binding }}$ & -7.94630387 \\
\hline & SD & 0.83996604 \\
\hline Daclatasvir & 1 & -6.743875 \\
\hline Daclatasvir & 2 & -6.5059676 \\
\hline Daclatasvir & 3 & -6.4129391 \\
\hline Daclatasvir & 4 & -6.2823424 \\
\hline Daclatasvir & 5 & -6.1425152 \\
\hline Daclatasvir & 6 & -6.1386223 \\
\hline Daclatasvir & 7 & -6.0960999 \\
\hline Daclatasvir & 8 & -6.0614023 \\
\hline Daclatasvir & 9 & -6.0143824 \\
\hline Daclatasvir & 10 & -6.008986 \\
\hline Daclatasvir & 11 & -5.9795341 \\
\hline Daclatasvir & 12 & -5.9727292 \\
\hline Daclatasvir & 13 & -5.9404788 \\
\hline Daclatasvir & 14 & -5.8896332 \\
\hline Daclatasvir & 15 & -5.8242784 \\
\hline Daclatasvir & 16 & -5.7552052 \\
\hline Daclatasvir & 17 & -5.6175394 \\
\hline Daclatasvir & 18 & -5.5847816 \\
\hline Daclatasvir & 19 & -5.5605044 \\
\hline Daclatasvir & 20 & -5.51682 \\
\hline Daclatasvir & 21 & -5.4841599 \\
\hline Daclatasvir & 22 & -5.4488587 \\
\hline Daclatasvir & 23 & -5.4191465 \\
\hline Daclatasvir & 24 & -5.2322726 \\
\hline \multirow[t]{3}{*}{ Daclatasvir } & 25 & -5.1832037 \\
\hline & Average $\Delta G_{\text {binding }}$ & -5.87265112 \\
\hline & SD & 0.3938991 \\
\hline Ombitasvir & 1 & -7.1596756 \\
\hline Ombitasvir & 2 & -6.8764935 \\
\hline Ombitasvir & 3 & -6.6037531 \\
\hline Ombitasvir & 4 & -6.2976608 \\
\hline Ombitasvir & 5 & -6.2173386 \\
\hline Ombitasvir & 6 & -6.1336923 \\
\hline Ombitasvir & 7 & -6.0335317 \\
\hline Ombitasvir & 8 & -5.9339681 \\
\hline Ombitasvir & 9 & -5.9162989 \\
\hline Ombitasvir & 10 & -5.8851943 \\
\hline Ombitasvir & 11 & -5.746839 \\
\hline Ombitasvir & 12 & -5.7327538 \\
\hline Ombitasvir & 13 & -5.6639748 \\
\hline Ombitasvir & 14 & -5.6421595 \\
\hline Ombitasvir & 15 & -5.6110668 \\
\hline Ombitasvir & 16 & -5.5996351 \\
\hline Ombitasvir & 17 & -5.4511547 \\
\hline Ombitasvir & 18 & -5.4373531 \\
\hline Ombitasvir & 19 & -5.4199243 \\
\hline Ombitasvir & 20 & -5.4113636 \\
\hline Ombitasvir & 21 & -5.3175464 \\
\hline Ombitasvir & 22 & -5.2385569 \\
\hline Ombitasvir & 23 & -5.1057653 \\
\hline Ombitasvir & 24 & -5.0913448 \\
\hline Ombitasvir & 25 & -4.9753966 \\
\hline Ombitasvir & 26 & -4.9052405 \\
\hline Ombitasvir & 27 & -4.8408008 \\
\hline Ombitasvir & 28 & -4.7974653 \\
\hline Ombitasvir & 29 & -4.776053 \\
\hline \multirow[t]{3}{*}{ Ombitasvir } & 30 & -4.5804648 \\
\hline & Average $\Delta \mathrm{G}_{\text {binding }}$ & -5.61341553 \\
\hline & SD & 0.62655319 \\
\hline
\end{tabular}




\begin{tabular}{|c|c|c|}
\hline Compound & Conformer & $\Delta$ Gbinding \\
\hline Camostat & 1 & -6.04285 \\
\hline Camostat & 2 & -5.9478555 \\
\hline Camostat & 3 & -5.9108286 \\
\hline Camostat & 4 & -5.886168 \\
\hline Camostat & 5 & -5.7768722 \\
\hline Camostat & 6 & -5.7290077 \\
\hline Camostat & 7 & -5.7062001 \\
\hline Camostat & 8 & -5.5547781 \\
\hline Camostat & 9 & -5.5303459 \\
\hline Camostat & 10 & -5.4542723 \\
\hline Camostat & 11 & -5.4306221 \\
\hline Camostat & 12 & -5.3901696 \\
\hline Camostat & 13 & -5.3401365 \\
\hline Camostat & 14 & -5.2483029 \\
\hline Camostat & 15 & -5.1767559 \\
\hline Camostat & 16 & -5.1755605 \\
\hline Camostat & 17 & -5.001894 \\
\hline Camostat & 18 & -4.9898071 \\
\hline Camostat & 19 & -4.9430857 \\
\hline Camostat & 20 & -4.876555 \\
\hline Camostat & 21 & -4.7852411 \\
\hline Camostat & 22 & -4.7760358 \\
\hline Camostat & 23 & -4.2693329 \\
\hline \multirow{3}{*}{ Camostat } & 24 & -3.7587805 \\
\hline & Average $\Delta G_{\text {binding }}$ & -5.27922742 \\
\hline & SD & 0.54872159 \\
\hline Edoxaban & 1 & -6.8826356 \\
\hline Edoxaban & 2 & -6.8416786 \\
\hline Edoxaban & 3 & -6.0505261 \\
\hline Edoxaban & 4 & -5.7649422 \\
\hline Edoxaban & 5 & -5.7016277 \\
\hline Edoxaban & 6 & -5.5783224 \\
\hline Edoxaban & 7 & -5.3962746 \\
\hline Edoxaban & 8 & -5.3227305 \\
\hline Edoxaban & 9 & -5.3205738 \\
\hline Edoxaban & 10 & -5.2506576 \\
\hline Edoxaban & 11 & -5.2484884 \\
\hline Edoxaban & 12 & -5.2288833 \\
\hline Edoxaban & 13 & -5.2250133 \\
\hline Edoxaban & 14 & -5.2120714 \\
\hline Edoxaban & 15 & -5.1705141 \\
\hline Edoxaban & 16 & -5.1128635 \\
\hline Edoxaban & 17 & -5.0910463 \\
\hline Edoxaban & 18 & -5.0524874 \\
\hline Edoxaban & 19 & -5.0045424 \\
\hline Edoxaban & 20 & -4.9296017 \\
\hline Edoxaban & 21 & -4.6752391 \\
\hline Edoxaban & 22 & -4.6085482 \\
\hline Edoxaban & 23 & -4.6075749 \\
\hline Edoxaban & 24 & -4.3654494 \\
\hline Edoxaban & 25 & -4.3570585 \\
\hline \multirow[t]{3}{*}{ Edoxaban } & 26 & -4.3081818 \\
\hline & Average $\Delta \mathrm{G}_{\text {binding }}$ & -5.24259742 \\
\hline & $\mathrm{SD}$ & 0.64259121 \\
\hline NCGC00386477 & 1 & -6.4412675 \\
\hline NCGC00386477 & 2 & -5.9841232 \\
\hline NCGC00386477 & 3 & -5.855576 \\
\hline NCGC00386477 & 4 & -5.7207823 \\
\hline NCGC00386477 & 5 & -5.6741104 \\
\hline NCGC00386477 & 6 & -5.6506562 \\
\hline NCGC00386477 & 7 & -5.6110411 \\
\hline NCGC00386477 & 8 & -5.4478011 \\
\hline NCGC00386477 & 9 & -5.4461803 \\
\hline
\end{tabular}




\begin{tabular}{|c|c|c|}
\hline Compound & Conformer & $\Delta$ Gbinding \\
\hline NCGC00386477 & 10 & -5.3958054 \\
\hline NCGC00386477 & 11 & -5.3548045 \\
\hline NCGC00386477 & 12 & -5.2550526 \\
\hline NCGC00386477 & 13 & -5.2438397 \\
\hline NCGC00386477 & 14 & -5.1881876 \\
\hline NCGC00386477 & 15 & -5.120954 \\
\hline NCGC00386477 & 16 & -5.0300746 \\
\hline NCGC00386477 & 17 & -5.0039954 \\
\hline NCGC00386477 & 18 & -4.8018866 \\
\hline NCGC00386477 & 19 & -4.7332406 \\
\hline NCGC00386477 & 20 & -4.7234364 \\
\hline NCGC00386477 & 21 & -4.636313 \\
\hline NCGC00386477 & 22 & -4.5279136 \\
\hline NCGC00386477 & 23 & -4.5238347 \\
\hline NCGC00386477 & 24 & -4.4817915 \\
\hline \multirow[t]{3}{*}{ NCGC00386477 } & 25 & -4.4324522 \\
\hline & Average $\Delta G_{\text {binding }}$ & -5.21140482 \\
\hline & SD & 0.52631492 \\
\hline Nafamostat & 1 & -5.783052 \\
\hline Nafamostat & 2 & -5.5672727 \\
\hline Nafamostat & 3 & -5.5662684 \\
\hline Nafamostat & 4 & -5.4643989 \\
\hline Nafamostat & 5 & -5.4622388 \\
\hline Nafamostat & 6 & -5.4363241 \\
\hline Nafamostat & 7 & -5.4281802 \\
\hline Nafamostat & 8 & -5.4156542 \\
\hline Nafamostat & 9 & -5.4117875 \\
\hline Nafamostat & 10 & -5.3318658 \\
\hline Nafamostat & 11 & -5.3077483 \\
\hline Nafamostat & 12 & -5.1793442 \\
\hline Nafamostat & 13 & -5.0623446 \\
\hline Nafamostat & 14 & -5.0086064 \\
\hline Nafamostat & 15 & -4.9340682 \\
\hline Nafamostat & 16 & -4.8842969 \\
\hline Nafamostat & 17 & -4.8719869 \\
\hline Nafamostat & 18 & -4.8711605 \\
\hline Nafamostat & 19 & -4.7926264 \\
\hline Nafamostat & 20 & -4.6345181 \\
\hline Nafamostat & 21 & -4.6133256 \\
\hline Nafamostat & 22 & -4.0774097 \\
\hline \multirow[t]{3}{*}{ Nafamostat } & 23 & -4.0382085 \\
\hline & Average $\Delta \mathrm{G}_{\text {binding }}$ & -5.0931603 \\
\hline & SD & 0.45703614 \\
\hline NCGC00386945 & 1 & -6.2677202 \\
\hline NCGC00386945 & 2 & -5.8147974 \\
\hline NCGC00386945 & 3 & -5.6708345 \\
\hline NCGC00386945 & 4 & -5.6003752 \\
\hline NCGC00386945 & 5 & -5.4398623 \\
\hline NCGC00386945 & 6 & -5.3755302 \\
\hline NCGC00386945 & 7 & -5.273097 \\
\hline NCGC00386945 & 8 & -5.2591763 \\
\hline NCGC00386945 & 9 & -5.2120218 \\
\hline NCGC00386945 & 10 & -5.1153016 \\
\hline NCGC00386945 & 11 & -5.1112304 \\
\hline NCGC00386945 & 12 & -5.0974422 \\
\hline NCGC00386945 & 13 & -5.0582089 \\
\hline NCGC00386945 & 14 & -4.9893522 \\
\hline NCGC00386945 & 15 & -4.8813934 \\
\hline NCGC00386945 & 16 & -4.8760819 \\
\hline NCGC00386945 & 17 & -4.8132668 \\
\hline NCGC00386945 & 18 & -4.797482 \\
\hline NCGC00386945 & 19 & -4.7948637 \\
\hline NCGC00386945 & 20 & -4.7915201 \\
\hline NCGC00386945 & 21 & -4.7686195 \\
\hline
\end{tabular}




\begin{tabular}{|c|c|c|}
\hline Compound & Conformer & $\Delta$ Gbinding \\
\hline NCGC00386945 & 22 & -4.6853576 \\
\hline NCGC00386945 & 23 & -4.6217885 \\
\hline NCGC00386945 & 24 & -4.4223056 \\
\hline NCGC00386945 & 25 & -4.0571074 \\
\hline \multirow[t]{3}{*}{ NCGC00386945 } & 26 & -4.0020714 \\
\hline & Average $\Delta \mathrm{G}_{\text {binding }}$ & -5.03064647 \\
\hline & SD & 0.50287184 \\
\hline Otamixaban & 1 & -6.0175567 \\
\hline Otamixaban & 2 & -5.7299685 \\
\hline Otamixaban & 3 & -5.6322932 \\
\hline Otamixaban & 4 & -5.56001 \\
\hline Otamixaban & 5 & -5.4496741 \\
\hline Otamixaban & 6 & -5.3958731 \\
\hline Otamixaban & 7 & -5.2923293 \\
\hline Otamixaban & 8 & -5.1934028 \\
\hline Otamixaban & 9 & -5.1780539 \\
\hline Otamixaban & 10 & -5.1540279 \\
\hline Otamixaban & 11 & -5.1525192 \\
\hline Otamixaban & 12 & -5.104033 \\
\hline Otamixaban & 13 & -5.0980663 \\
\hline Otamixaban & 14 & -5.0828133 \\
\hline Otamixaban & 15 & -5.0513377 \\
\hline Otamixaban & 16 & -5.0475435 \\
\hline Otamixaban & 17 & -4.9834208 \\
\hline Otamixaban & 18 & -4.7533231 \\
\hline Otamixaban & 19 & -4.73839 \\
\hline Otamixaban & 20 & -4.7017422 \\
\hline Otamixaban & 21 & -4.6069565 \\
\hline Otamixaban & 22 & -4.6006813 \\
\hline Otamixaban & 23 & -4.4703946 \\
\hline Otamixaban & 24 & -4.2730875 \\
\hline Otamixaban & 25 & -4.076292 \\
\hline \multirow[t]{3}{*}{ Otamixaban } & 26 & -3.9181862 \\
\hline & Average $\Delta \mathrm{G}_{\text {binding }}$ & -5.01007603 \\
\hline & SD & 0.49946414 \\
\hline Darexaban & 1 & -5.824955 \\
\hline Darexaban & 2 & -5.7299123 \\
\hline Darexaban & 3 & -5.563283 \\
\hline Darexaban & 4 & -5.4950666 \\
\hline Darexaban & 5 & -5.4491625 \\
\hline Darexaban & 6 & -5.3575301 \\
\hline Darexaban & 7 & -5.3437848 \\
\hline Darexaban & 8 & -5.3057985 \\
\hline Darexaban & 9 & -5.2480159 \\
\hline Darexaban & 10 & -5.1242046 \\
\hline Darexaban & 11 & -5.088347 \\
\hline Darexaban & 12 & -5.0795984 \\
\hline Darexaban & 13 & -5.0567398 \\
\hline Darexaban & 14 & -4.9246492 \\
\hline Darexaban & 15 & -4.8271747 \\
\hline Darexaban & 16 & -4.8004422 \\
\hline Darexaban & 17 & -4.7597399 \\
\hline Darexaban & 18 & -4.7581606 \\
\hline Darexaban & 19 & -4.7405477 \\
\hline Darexaban & 20 & -4.7084093 \\
\hline Darexaban & 21 & -4.6985788 \\
\hline Darexaban & 22 & -4.6422806 \\
\hline Darexaban & 23 & -4.6402278 \\
\hline Darexaban & 24 & -4.3252153 \\
\hline Darexaban & 25 & -4.0919528 \\
\hline \multirow[t]{3}{*}{ Darexaban } & 26 & -3.9560533 \\
\hline & Average $\Delta G_{\text {binding }}$ & -4.98230118 \\
\hline & SD & 0.46754746 \\
\hline
\end{tabular}




\begin{tabular}{|c|c|c|}
\hline Compound & Conformer & $\Delta$ Gbinding \\
\hline Gabexate & 1 & -5.3681436 \\
\hline Gabexate & 2 & -5.3153243 \\
\hline Gabexate & 3 & -5.3048029 \\
\hline Gabexate & 4 & -5.2681551 \\
\hline Gabexate & 5 & -5.2648449 \\
\hline Gabexate & 6 & -5.2557278 \\
\hline Gabexate & 7 & -5.2517371 \\
\hline Gabexate & 8 & -5.251121 \\
\hline Gabexate & 9 & -5.2271938 \\
\hline Gabexate & 10 & -5.2255993 \\
\hline Gabexate & 11 & -5.0875754 \\
\hline Gabexate & 12 & -5.0553536 \\
\hline Gabexate & 13 & -4.9865375 \\
\hline Gabexate & 14 & -4.9838514 \\
\hline Gabexate & 15 & -4.9834967 \\
\hline Gabexate & 16 & -4.9718957 \\
\hline Gabexate & 17 & -4.9123788 \\
\hline Gabexate & 18 & -4.9057102 \\
\hline Gabexate & 19 & -4.8976898 \\
\hline Gabexate & 20 & -4.7917051 \\
\hline Gabexate & 21 & -4.7875376 \\
\hline Gabexate & 22 & -4.6820951 \\
\hline Gabexate & 23 & -4.6785526 \\
\hline Gabexate & 24 & -4.5578337 \\
\hline Gabexate & 25 & -4.5536962 \\
\hline Gabexate & 26 & -4.5354271 \\
\hline Gabexate & 27 & -4.5288396 \\
\hline Gabexate & 28 & -4.5122361 \\
\hline \multirow[t]{3}{*}{ Gabexate } & 29 & -4.3295536 \\
\hline & Average $\Delta G_{\text {binding }}$ & -4.94740054 \\
\hline & SD & 0.30095941 \\
\hline Letaxaban & 1 & -5.9555793 \\
\hline Letaxaban & 2 & -5.4709511 \\
\hline Letaxaban & 3 & -5.4403868 \\
\hline Letaxaban & 4 & -5.3879633 \\
\hline Letaxaban & 5 & -5.3490348 \\
\hline Letaxaban & 6 & -5.3032179 \\
\hline Letaxaban & 7 & -5.2313886 \\
\hline Letaxaban & 8 & -5.2235136 \\
\hline Letaxaban & 9 & -5.1020436 \\
\hline Letaxaban & 10 & -5.0208097 \\
\hline Letaxaban & 11 & -4.9803667 \\
\hline Letaxaban & 12 & -4.9308438 \\
\hline Letaxaban & 13 & -4.8757157 \\
\hline Letaxaban & 14 & -4.8737264 \\
\hline Letaxaban & 15 & -4.7332249 \\
\hline Letaxaban & 16 & -4.6809821 \\
\hline Letaxaban & 17 & -4.649158 \\
\hline Letaxaban & 18 & -4.6135006 \\
\hline Letaxaban & 19 & -4.5755901 \\
\hline Letaxaban & 20 & -4.5001082 \\
\hline Letaxaban & 21 & -4.4170842 \\
\hline Letaxaban & 22 & -4.3670373 \\
\hline Letaxaban & 23 & -4.3472133 \\
\hline Letaxaban & 24 & -4.0853858 \\
\hline Letaxaban & 25 & -3.9305549 \\
\hline \multirow[t]{3}{*}{ Letaxaban } & 26 & -3.8967683 \\
\hline & Average $\Delta G_{\text {binding }}$ & -4.84392881 \\
\hline & $\mathrm{SD}$ & 0.50794032 \\
\hline Argatroban & 1 & -5.9366364 \\
\hline Argatroban & 2 & -5.7820024 \\
\hline Argatroban & 3 & -5.5289149 \\
\hline Argatroban & 4 & -5.1951489 \\
\hline Argatroban & 5 & -5.10601 \\
\hline
\end{tabular}




\begin{tabular}{|c|c|c|}
\hline Compound & Conformer & $\Delta$ Gbinding \\
\hline Argatroban & 6 & -5.0797424 \\
\hline Argatroban & 7 & -5.0044961 \\
\hline Argatroban & 8 & -4.9989691 \\
\hline Argatroban & 9 & -4.9438901 \\
\hline Argatroban & 10 & -4.9209909 \\
\hline Argatroban & 11 & -4.8325586 \\
\hline Argatroban & 12 & -4.8318486 \\
\hline Argatroban & 13 & -4.7511015 \\
\hline Argatroban & 14 & -4.746994 \\
\hline Argatroban & 15 & -4.7196827 \\
\hline Argatroban & 16 & -4.6884422 \\
\hline Argatroban & 17 & -4.6304469 \\
\hline Argatroban & 18 & -4.5986891 \\
\hline Argatroban & 19 & -4.5740185 \\
\hline Argatroban & 20 & -4.5497618 \\
\hline Argatroban & 21 & -4.5403342 \\
\hline Argatroban & 22 & -4.479043 \\
\hline Argatroban & 23 & -4.429338 \\
\hline Argatroban & 24 & -4.3240738 \\
\hline Argatroban & 25 & -4.2996855 \\
\hline Argatroban & 26 & -4.2566605 \\
\hline Argatroban & 27 & -4.1599746 \\
\hline Argatroban & 28 & -4.1448326 \\
\hline \multirow{3}{*}{ Argatroban } & 29 & -3.911803 \\
\hline & Average $\Delta \mathrm{G}_{\text {binding }}$ & -4.75745139 \\
\hline & $\mathrm{SD}$ & 0.466623475 \\
\hline Sivelestat & 1 & -5.7663693 \\
\hline Sivelestat & 2 & -5.6685505 \\
\hline Sivelestat & 3 & -5.2513843 \\
\hline Sivelestat & 4 & -5.1074672 \\
\hline Sivelestat & 5 & -5.0676432 \\
\hline Sivelestat & 6 & -4.8846173 \\
\hline Sivelestat & 7 & -4.7638769 \\
\hline Sivelestat & 8 & -4.667614 \\
\hline Sivelestat & 9 & -4.6333213 \\
\hline Sivelestat & 10 & -4.6255341 \\
\hline Sivelestat & 11 & -4.5483212 \\
\hline Sivelestat & 12 & -4.5314074 \\
\hline Sivelestat & 13 & -4.4784012 \\
\hline Sivelestat & 14 & -4.4594836 \\
\hline Sivelestat & 15 & -4.4470592 \\
\hline Sivelestat & 16 & -4.4107747 \\
\hline Sivelestat & 17 & -4.4071817 \\
\hline Sivelestat & 18 & -4.3835483 \\
\hline Sivelestat & 19 & -4.3009076 \\
\hline Sivelestat & 20 & -4.2904139 \\
\hline Sivelestat & 21 & -4.2799411 \\
\hline Sivelestat & 22 & -4.2648997 \\
\hline Sivelestat & 23 & -4.2099204 \\
\hline Sivelestat & 24 & -4.0479288 \\
\hline Sivelestat & 25 & -3.980907 \\
\hline \multirow[t]{3}{*}{ Sivelestat } & 26 & -3.9492056 \\
\hline & Average $\Delta \mathrm{G}_{\text {binding }}$ & -4.59333383 \\
\hline & SD & 0.46323607 \\
\hline NCGC00385043 & 1 & -4.8091416 \\
\hline NCGC00385043 & 2 & -4.8008184 \\
\hline NCGC00385043 & 3 & -4.7585044 \\
\hline NCGC00385043 & 4 & -4.6344757 \\
\hline NCGC00385043 & 5 & -4.6077566 \\
\hline NCGC00385043 & 6 & -4.5341458 \\
\hline NCGC00385043 & 7 & -4.5100379 \\
\hline NCGC00385043 & 8 & -4.4895115 \\
\hline NCGC00385043 & 9 & -4.4750743 \\
\hline NCGC00385043 & 10 & -4.4554081 \\
\hline
\end{tabular}




\begin{tabular}{|c|c|c|}
\hline Compound & Conformer & $\Delta$ Gbinding \\
\hline NCGC00385043 & 11 & -4.3122907 \\
\hline NCGC00385043 & 12 & -4.2755661 \\
\hline NCGC00385043 & 13 & -4.26647 \\
\hline NCGC00385043 & 14 & -4.2525153 \\
\hline NCGC00385043 & 15 & -4.2013316 \\
\hline NCGC00385043 & 16 & -4.1468425 \\
\hline NCGC00385043 & 17 & -4.1188512 \\
\hline NCGC00385043 & 18 & -4.1005011 \\
\hline NCGC00385043 & 19 & -4.0778847 \\
\hline NCGC00385043 & 20 & -4.0708661 \\
\hline NCGC00385043 & 21 & -4.048614 \\
\hline NCGC00385043 & 22 & -4.0453215 \\
\hline NCGC00385043 & 23 & -4.0339699 \\
\hline NCGC00385043 & 24 & -4.0254369 \\
\hline NCGC 00385043 & 25 & -3.9995716 \\
\hline NCGC00385043 & 26 & -3.9956882 \\
\hline NCGC00385043 & 27 & -3.8087223 \\
\hline NCGC00385043 & 28 & -3.6315114 \\
\hline NCGC00385043 & 29 & -3.5687988 \\
\hline \multirow[t]{3}{*}{ NCGC00385043 } & 30 & -3.500308 \\
\hline & Average $\Delta \mathrm{G}_{\text {binding }}$ & -4.21853121 \\
\hline & SD & 0.34484591 \\
\hline Bromhexine & 1 & -4.53442 \\
\hline Bromhexine & 2 & -4.4252768 \\
\hline Bromhexine & 3 & -4.3771749 \\
\hline Bromhexine & 4 & -4.2960958 \\
\hline Bromhexine & 5 & -4.2618198 \\
\hline Bromhexine & 6 & -4.2172284 \\
\hline Bromhexine & 7 & -4.2078066 \\
\hline Bromhexine & 8 & -4.1676679 \\
\hline Bromhexine & 9 & -4.0720615 \\
\hline Bromhexine & 10 & -4.0715098 \\
\hline Bromhexine & 11 & -4.0458279 \\
\hline Bromhexine & 12 & -4.0063806 \\
\hline Bromhexine & 13 & -3.9147584 \\
\hline Bromhexine & 14 & -3.8586266 \\
\hline Bromhexine & 15 & -3.7951355 \\
\hline Bromhexine & 16 & -3.7394795 \\
\hline Bromhexine & 17 & -3.7024744 \\
\hline Bromhexine & 18 & -3.5915985 \\
\hline Bromhexine & 19 & -3.5772321 \\
\hline Bromhexine & 20 & -3.5499673 \\
\hline \multirow[t]{3}{*}{ Bromhexine } & 21 & -3.5254657 \\
\hline & Average $\Delta \mathrm{G}_{\text {binding }}$ & -3.997048 \\
\hline & SD & 0.30777818 \\
\hline
\end{tabular}

Equivalence of the number of amino acids, between the generated model of TMPRSS2 and the Uniprot sequence 015393 TMPS2_Human, for the analysis of the interactions shown below.

\begin{tabular}{l|l}
\hline O15393 TMPS2_Human & TMPRSS2 Model for molecular docking \\
\hline Val280 & Val187 \\
\hline His296 & His203 \\
\hline Glu299 & Glu206 \\
\hline Asp435 & Asp347 \\
\hline Ser436 & Ser348 \\
\hline Cys437 & Cys349 \\
\hline Gln438 & Gln350 \\
\hline Ser441 & Ser353 \\
\hline Gly462 & Gly378 \\
\hline Ser463 & Ser379 \\
\hline Gly464 & Gly380 \\
\hline Cys465 & Cys381 \\
\hline Lys467 & Lys383
\end{tabular}


Table S2. Interaction report of each conformer of compound T1. Number of conformer, Atom of compound,

Amino acid in TMPRSS2, Type of interaction and Distance in angstroms.

\begin{tabular}{|c|c|c|c|c|c|}
\hline \multirow{2}{*}{$\begin{array}{c}\text { Conformer } \\
1 \\
\end{array}$} & \multirow{2}{*}{$\begin{array}{l}\text { Ligand } \\
\mathrm{N}\end{array}$} & \multicolumn{2}{|c|}{ Residues in TMPRSS2 } & \multirow{2}{*}{$\begin{array}{c}\text { Interaction } \\
\text { H-donor }\end{array}$} & \multirow{2}{*}{$\begin{array}{c}\text { Distance } \\
3.47\end{array}$} \\
\hline & & SER & 348 & & \\
\hline & $\mathrm{O}$ & HIS & 203 & H-acceptor & 3.05 \\
\hline & 6-ring & CYS & 381 & pi-H & 4.17 \\
\hline \multirow[t]{2}{*}{2} & $\mathrm{~N}$ & CYS & 349 & H-donor & 3.08 \\
\hline & 6-ring & CYS & 381 & pi-H & 4.16 \\
\hline \multirow[t]{2}{*}{3} & $\mathrm{~N}$ & GLY & 378 & H-donor & 3.2 \\
\hline & $\mathrm{O}$ & HIS & 203 & H-acceptor & 2.97 \\
\hline \multirow[t]{2}{*}{4} & $\mathrm{~N}$ & CYS & 349 & H-donor & 3.35 \\
\hline & $\mathrm{O}$ & HIS & 203 & H-acceptor & 2.98 \\
\hline \multirow[t]{2}{*}{5} & $\mathrm{~N}$ & CYS & 349 & H-donor & 2.98 \\
\hline & 6-ring & CYS & 381 & pi-H & 4.15 \\
\hline \multirow[t]{2}{*}{6} & $\mathrm{~N}$ & CYS & 349 & H-donor & 3.08 \\
\hline & 6-ring & CYS & 381 & pi-H & 4.19 \\
\hline \multirow[t]{2}{*}{7} & $\mathrm{O}$ & HIS & 203 & H-acceptor & 3.14 \\
\hline & 6-ring & GLY & 380 & pi-H & 3.87 \\
\hline \multirow[t]{2}{*}{8} & $\mathrm{~N}$ & GLY & 378 & H-donor & 3.22 \\
\hline & $\mathrm{O}$ & HIS & 203 & H-acceptor & 3.18 \\
\hline \multirow[t]{2}{*}{9} & $\mathrm{O}$ & HIS & 203 & H-acceptor & 3.04 \\
\hline & 6-ring & GLY & 380 & pi-H & 3.98 \\
\hline \multirow[t]{2}{*}{10} & $\mathrm{O}$ & HIS & 203 & H-acceptor & 3.52 \\
\hline & 6-ring & CYS & 381 & pi-H & 4.45 \\
\hline 11 & $\mathrm{O}$ & HIS & 203 & H-acceptor & 3.05 \\
\hline \multirow[t]{3}{*}{12} & $\mathrm{~N}$ & SER & 348 & H-donor & 3.35 \\
\hline & $\mathrm{N}$ & LYS & 383 & H-acceptor & 3.29 \\
\hline & $\mathrm{O}$ & HIS & 203 & H-acceptor & 3 \\
\hline \multirow[t]{2}{*}{13} & $\mathrm{~N}$ & SER & 379 & H-donor & 3.4 \\
\hline & $\mathrm{N}$ & HIS & 203 & H-acceptor & 3.48 \\
\hline 14 & $\mathrm{~N}$ & VAL & 187 & H-donor & 4.04 \\
\hline \multirow[t]{2}{*}{15} & $\mathrm{~N}$ & ASN & 249 & H-acceptor & 3.31 \\
\hline & 6-ring & HIS & 203 & pi-cation & 4.45 \\
\hline \multirow[t]{2}{*}{16} & $\mathrm{~N}$ & HIS & 203 & H-acceptor & 3.26 \\
\hline & 6-ring & GLY & 378 & pi-H & 4.26 \\
\hline \multirow[t]{2}{*}{17} & $\mathrm{~N}$ & ASN & 249 & H-acceptor & 3.34 \\
\hline & 6-ring & GLY & 380 & pi-H & 3.81 \\
\hline 18 & $\mathrm{O}$ & GLY & 351 & H-acceptor & 3.08 \\
\hline 19 & $\mathrm{O}$ & GLY & 351 & H-acceptor & 3.02 \\
\hline \multirow[t]{2}{*}{20} & $\mathrm{O}$ & HIS & 203 & H-acceptor & 3.37 \\
\hline & 6-ring & GLY & 380 & pi-H & 3.76 \\
\hline 21 & $\mathrm{O}$ & HIS & 203 & H-acceptor & 3.23 \\
\hline \multirow[t]{2}{*}{22} & $\mathrm{~N}$ & GLY & 351 & H-acceptor & 3.59 \\
\hline & $\mathrm{O}$ & HIS & 203 & H-acceptor & 3.24 \\
\hline 23 & $\mathrm{O}$ & HIS & 203 & H-acceptor & 3.21 \\
\hline 24 & $\mathrm{~N}$ & GLU & 206 & H-donor & 3.25 \\
\hline \multirow[t]{2}{*}{25} & $\mathrm{O}$ & HIS & 203 & H-acceptor & 3.12 \\
\hline & 6-ring & GLY & 380 & pi-H & 3.93 \\
\hline 26 & $\mathrm{~N}$ & GLY & 351 & H-acceptor & 3.22 \\
\hline 27 & $\mathrm{~N}$ & GLY & 351 & H-acceptor & 3.35 \\
\hline & $\mathrm{N}$ & GLY & 380 & H-acceptor & 3.61 \\
\hline
\end{tabular}

Table S3. Interaction report of each conformer of compound T2. Number of conformer, Atom of compound, Amino acid in TMPRSS2, Type of interaction and Distance in angstroms.

\begin{tabular}{c|l|c|c|c|c} 
Conformer & Ligand & \multicolumn{2}{c}{ Residues in TMPRSS2 } & Interaction & Distance \\
\hline $\mathbf{1}$ & S & VAL & 187 & H-donor & 3.32 \\
\hline & C & GLU & 206 & H-donor & 3.55 \\
\hline & N & HIS & 203 & H-acceptor & 3.4 \\
\hline & O & HIS & 203 & H-acceptor & 3.43 \\
\hline $\mathbf{2}$ & S & VAL & 187 & H-donor & 3.21 \\
\hline & C & GLU & 206 & H-donor & 3.49 \\
\hline & N & HIS & 203 & H-acceptor & 3.45 \\
\hline & O & HIS & 203 & H-acceptor & 3.1 \\
\hline $\mathbf{3}$ & O & HIS & 203 & H-acceptor & 3.25 \\
\hline & 6-ring & LEU & 209 & pi-H & 3.74 \\
\hline $\mathbf{4}$ & N & VAL & 187 & H-donor & 3.09
\end{tabular}




\begin{tabular}{|c|c|c|c|c|c|}
\hline Conformer & Ligand & Residues in & TMPRSS2 & Interaction & Distance \\
\hline & 5-ring & GLY & 351 & pi-H & 3.98 \\
\hline \multirow[t]{2}{*}{5} & $\mathrm{~N}$ & VAL & 187 & H-donor & 2.98 \\
\hline & 6-ring & HIS & 203 & pi-cation & 3.59 \\
\hline \multirow[t]{3}{*}{6} & $\mathrm{~N}$ & HIS & 203 & H-acceptor & 3.59 \\
\hline & $\mathrm{O}$ & HIS & 203 & H-acceptor & 3.1 \\
\hline & $\mathrm{O}$ & HIS & 203 & H-acceptor & 3.29 \\
\hline 7 & $\mathrm{~N}$ & GLU & 206 & H-donor & 2.93 \\
\hline \multirow[t]{3}{*}{8} & $\mathrm{~N}$ & VAL & 187 & H-donor & 3.15 \\
\hline & $\mathrm{N}$ & HIS & 203 & H-acceptor & 3.82 \\
\hline & $\mathrm{O}$ & HIS & 203 & H-acceptor & 3 \\
\hline 9 & 6-ring & GLY & 351 & pi-H & 3.57 \\
\hline \multirow[t]{3}{*}{11} & 6-ring & TYR & 250 & pi-H & 4.49 \\
\hline & 6-ring & GLN & 350 & pi-H & 4.52 \\
\hline & 6-ring & GLY & 351 & pi-H & 4.34 \\
\hline \multirow[t]{3}{*}{12} & $\mathrm{~S}$ & SER & 348 & H-donor & 3.26 \\
\hline & $\mathrm{O}$ & HIS & 203 & H-acceptor & 3.1 \\
\hline & 6-ring & CYS & 204 & pi-H & 4.2 \\
\hline 13 & $\mathrm{O}$ & HIS & 203 & H-acceptor & 2.96 \\
\hline 14 & $\mathrm{O}$ & HIS & 203 & H-acceptor & 3.29 \\
\hline 15 & $\mathrm{~N}$ & GLY & 351 & H-acceptor & 3.11 \\
\hline \multirow[t]{3}{*}{16} & $S$ & GLU & 206 & H-donor & 3.35 \\
\hline & 6-ring & HIS & 203 & pi-cation & 3.92 \\
\hline & 6-ring & GLY & 351 & pi-H & 4.07 \\
\hline \multirow[t]{2}{*}{17} & S & SER & 348 & H-donor & 3.3 \\
\hline & 5-ring & GLN & 350 & pi-H & 4.18 \\
\hline \multirow[t]{2}{*}{18} & $\mathrm{O}$ & HIS & 203 & H-acceptor & 3.09 \\
\hline & 6-ring & GLY & 351 & pi-H & 3.45 \\
\hline \multirow[t]{2}{*}{19} & $\mathrm{O}$ & HIS & 203 & H-acceptor & 2.91 \\
\hline & 6-ring & CYS & 204 & pi-H & 3.9 \\
\hline \multirow[t]{2}{*}{20} & $\mathrm{O}$ & HIS & 203 & H-acceptor & 2.99 \\
\hline & 5-ring & GLY & 351 & pi-H & 3.72 \\
\hline \multirow[t]{2}{*}{21} & 6-ring & HIS & 203 & pi-H & 3.71 \\
\hline & 6-ring & HIS & 203 & pi-cation & 3.71 \\
\hline \multirow[t]{2}{*}{22} & $\mathrm{O}$ & GLY & 351 & H-acceptor & 3.23 \\
\hline & 6-ring & CYS & 204 & pi-H & 4.32 \\
\hline 23 & $\mathrm{~N}$ & GLY & 378 & H-donor & 3.06 \\
\hline 24 & 5-ring & HIS & 203 & pi-cation & 3.38 \\
\hline
\end{tabular}

Table S4. Interaction report of each conformer of compound T3. Number of conformer, Atom of compound,

Amino acid in TMPRSS2, Type of interaction and Distance in angstroms.

\begin{tabular}{|c|c|c|c|c|c|}
\hline \multirow{2}{*}{$\begin{array}{c}\text { Conformer } \\
1 \\
\end{array}$} & \multirow{2}{*}{$\begin{array}{l}\text { Ligand } \\
\mathrm{C} \\
\end{array}$} & \multicolumn{2}{|c|}{ Residues in TMPRSS2 } & \multirow{2}{*}{$\begin{array}{r}\text { Interaction } \\
\mathrm{H} \text {-donor }\end{array}$} & \multirow{2}{*}{$\begin{array}{c}\text { Distance } \\
3.44\end{array}$} \\
\hline & & GLY & 378 & & \\
\hline & $\mathrm{O}$ & HIS & 203 & H-acceptor & 3.33 \\
\hline \multirow[t]{3}{*}{2} & $\mathrm{~S}$ & SER & 376 & H-donor & 3.88 \\
\hline & 5-ring & HIS & 203 & pi-cation & 3.33 \\
\hline & 6-ring & TRP & 377 & pi-H & 4.72 \\
\hline 3 & 5-ring & VAL & 187 & pi-H & 4.1 \\
\hline \multirow[t]{4}{*}{4} & $\mathrm{~S}$ & SER & 348 & H-donor & 3.83 \\
\hline & $\mathrm{S}$ & CYS & 381 & H-donor & 3.67 \\
\hline & $\mathrm{S}$ & VAL & 187 & H-donor & 4.03 \\
\hline & $\mathrm{N}$ & HIS & 203 & H-acceptor & 3.35 \\
\hline \multirow[t]{2}{*}{5} & $\mathrm{~S}$ & SER & 348 & H-donor & 3.53 \\
\hline & $\mathrm{S}$ & CYS & 381 & H-donor & 4.25 \\
\hline 6 & $\mathrm{~N}$ & VAL & 187 & H-donor & 2.92 \\
\hline 7 & $\mathrm{~N}$ & GLY & 351 & H-acceptor & 3.34 \\
\hline 8 & 6-ring & GLY & 378 & pi-H & 3.99 \\
\hline 9 & $\mathrm{~N}$ & GLY & 351 & H-acceptor & 3.37 \\
\hline \multirow[t]{4}{*}{10} & $\mathrm{~S}$ & VAL & 205 & H-donor & 3.55 \\
\hline & $\mathrm{S}$ & GLU & 206 & H-donor & 3.73 \\
\hline & 5-ring & VAL & 187 & pi-H & 3.65 \\
\hline & 5-ring & VAL & 187 & pi-H & 4.03 \\
\hline \multirow[t]{3}{*}{11} & $\mathrm{~N}$ & HIS & 203 & H-acceptor & 3.41 \\
\hline & $\mathrm{N}$ & HIS & 203 & H-acceptor & 3.05 \\
\hline & $\mathrm{O}$ & GLY & 351 & H-acceptor & 3.24 \\
\hline 12 & $\mathrm{O}$ & HIS & 203 & H-acceptor & 3.04 \\
\hline 13 & $\mathrm{~S}$ & HIS & 203 & H-donor & 3.87 \\
\hline
\end{tabular}




\begin{tabular}{c|l|c|c|c|c}
\multirow{2}{*}{ Conformer } & Ligand & \multicolumn{2}{|c|}{ Residues in TMPRSS } & Interaction & Distance \\
\hline & S & ASN & 249 & H-donor & 3.28 \\
\hline & S & SER & 353 & H-donor & 3.95 \\
\hline & S & GLY & 378 & H-donor & 3.9 \\
\hline $\mathbf{1 4}$ & S & VAL & 187 & H-donor & 3.34 \\
\hline & S & GLY & 351 & H-donor & 3.24 \\
\hline $\mathbf{1 5}$ & N & GLU & 206 & H-donor & 2.95 \\
\hline & S & VAL & 205 & H-donor & 3.88 \\
\hline & S & GLU & 206 & H-donor & 3.58 \\
\hline $\mathbf{1 6}$ & 5-ring & VAL & 187 & pi-H & 4.97 \\
\hline $\mathbf{1 7}$ & O & HIS & 203 & H-acceptor & 2.87 \\
\hline & 5-ring & GLY & 378 & pi-H & 4.62 \\
\hline $\mathbf{1 8}$ & 5-ring & GLN & 350 & pi-H & 4.3 \\
\hline $\mathbf{1 9}$ & S & GLY & 351 & H-donor & 3.67 \\
\hline $\mathbf{2 0}$ & 6-ring & HIS & 203 & pi-cation & 3.46 \\
\hline & S & GLU & 206 & H-donor & 3.16 \\
\hline & N & HIS & 203 & H-acceptor & 3.31 \\
\hline & N & HIS & 203 & H-acceptor & 3.34 \\
\hline $\mathbf{2 1}$ & N & HIS & 203 & H-acceptor & 3 \\
\hline & 5-ring & GLY & 351 & H-acceptor & 2.86 \\
\hline & 5-ring & GAL & 187 & pi-H & 4.63 \\
\hline $\mathbf{2 2}$ & 5-ring & VAL & 187 & pi-H & 3.76 \\
\hline $\mathbf{2 3}$ & S & GLY & 378 & H-donor & 3.72 \\
\hline & S & ASN & 249 & H-donor & 3.45 \\
\hline & O & TYR & 250 & H-acceptor & 3 \\
\hline & O & ASN & 249 & H-acceptor & 3 \\
\hline & & & & &
\end{tabular}

Table S5. Interaction report of each conformer of compound T4. Number of conformer, Atom of compound, Amino acid in TMPRSS2, Type of interaction and Distance in angstroms.

\begin{tabular}{|c|c|c|c|c|c|}
\hline \multirow{2}{*}{$\frac{\text { Conformer }}{1}$} & \multirow{2}{*}{$\frac{\text { Ligand }}{\mathrm{N}}$} & \multicolumn{2}{|c|}{ Residues in TMPRSS2 } & \multirow{2}{*}{$\frac{\text { Interaction }}{\mathrm{H} \text {-donor }}$} & \multirow{2}{*}{$\frac{\text { Distance }}{3}$} \\
\hline & & GLY & 378 & & \\
\hline & $\mathrm{N}$ & HIS & 203 & H-acceptor & 3.41 \\
\hline 2 & $\mathrm{~N}$ & CYS & 349 & H-donor & 3.06 \\
\hline \multirow[t]{3}{*}{3} & $\mathrm{~S}$ & HIS & 203 & H-donor & 4.27 \\
\hline & $\mathrm{N}$ & CYS & 349 & H-donor & 3 \\
\hline & 6-ring & GLY & 380 & pi-H & 3.77 \\
\hline \multirow[t]{4}{*}{4} & $\mathrm{~N}$ & GLY & 378 & H-donor & 3.05 \\
\hline & $\mathrm{N}$ & HIS & 203 & $\mathrm{H}$-acceptor & 3.22 \\
\hline & $\mathrm{O}$ & GLY & 351 & H-acceptor & 2.95 \\
\hline & 6-ring & VAL & 187 & pi-H & 4.17 \\
\hline \multirow[t]{3}{*}{5} & $\mathrm{~N}$ & GLU & 206 & H-donor & 2.86 \\
\hline & $\mathrm{N}$ & VAL & 187 & H-donor & 3.03 \\
\hline & 6-ring & LEU & 209 & pi-H & 3.93 \\
\hline \multirow[t]{5}{*}{6} & $\mathrm{~S}$ & GLY & 351 & H-donor & 3.49 \\
\hline & $S$ & SER & 348 & H-donor & 4.03 \\
\hline & $\mathrm{O}$ & THR & 254 & H-acceptor & 3.15 \\
\hline & 5-ring & HIS & 203 & pi-H & 3.67 \\
\hline & 6-ring & CYS & 204 & pi-H & 3.82 \\
\hline \multirow[t]{4}{*}{7} & $\mathrm{~S}$ & SER & 348 & H-donor & 3.63 \\
\hline & $\mathrm{C}$ & $\mathrm{ASN}$ & 249 & H-donor & 3.42 \\
\hline & $\mathrm{O}$ & TYR & 250 & H-acceptor & 3.15 \\
\hline & $\mathrm{O}$ & $\mathrm{ASN}$ & 249 & H-acceptor & 3.11 \\
\hline 8 & $\mathrm{~N}$ & HIS & 203 & $\mathrm{H}$-acceptor & 3.15 \\
\hline \multirow[t]{3}{*}{9} & $\mathrm{C}$ & $\mathrm{ASN}$ & 249 & H-donor & 3.42 \\
\hline & $\mathrm{O}$ & TYR & 250 & H-acceptor & 3.16 \\
\hline & $\mathrm{O}$ & ASN & 249 & H-acceptor & 3.12 \\
\hline \multirow[t]{2}{*}{10} & $\mathrm{~N}$ & VAL & 187 & H-donor & 3.17 \\
\hline & 6-ring & GLY & 380 & pi-H & 4.28 \\
\hline \multirow[t]{2}{*}{11} & $\mathrm{~N}$ & HIS & 203 & H-acceptor & 3.18 \\
\hline & 6-ring & VAL & 187 & pi-H & 3.98 \\
\hline \multirow[t]{4}{*}{12} & S & HIS & 203 & H-donor & 3.93 \\
\hline & $\mathrm{N}$ & CYS & 349 & H-donor & 3.36 \\
\hline & $\mathrm{C}$ & VAL & 187 & H-donor & 3.34 \\
\hline & 5-ring & GLY & 351 & pi-H & 4.11 \\
\hline \multirow[t]{2}{*}{13} & $\mathrm{~S}$ & HIS & 203 & H-donor & 4.16 \\
\hline & $\mathrm{O}$ & CYS & 381 & H-donor & 3.95 \\
\hline
\end{tabular}




\begin{tabular}{|c|c|c|c|c|c|}
\hline \multirow{2}{*}{ Conformer } & \multirow{2}{*}{$\begin{array}{l}\text { Ligand } \\
\mathrm{O}\end{array}$} & \multicolumn{2}{|c|}{ Residues in TMPRSS2 } & \multirow{2}{*}{$\frac{\text { Interaction }}{\text { H-acceptor }}$} & \multirow{2}{*}{$\begin{array}{c}\text { Distance } \\
3.39\end{array}$} \\
\hline & & CYS & 381 & & \\
\hline 14 & 6-ring & ASN & 249 & pi-H & 3.61 \\
\hline \multirow[t]{2}{*}{15} & $\mathrm{~N}$ & GLU & 206 & H-donor & 2.9 \\
\hline & $\mathrm{N}$ & VAL & 187 & H-donor & 2.99 \\
\hline \multirow[t]{3}{*}{16} & $\mathrm{~N}$ & VAL & 187 & H-donor & 2.97 \\
\hline & 6-ring & LYS & 302 & pi-H & 4.58 \\
\hline & 6-ring & GLY & 303 & pi-H & 3.73 \\
\hline 17 & 5-ring & VAL & 187 & pi-H & 3.84 \\
\hline \multirow[t]{4}{*}{18} & $\mathrm{~N}$ & GLU & 206 & H-donor & 3.12 \\
\hline & $\mathrm{C}$ & GLU & 206 & H-donor & 3.63 \\
\hline & $\mathrm{C}$ & VAL & 187 & H-donor & 3.38 \\
\hline & $\mathrm{O}$ & HIS & 203 & H-acceptor & 3.65 \\
\hline \multirow[t]{3}{*}{19} & $\mathrm{~N}$ & HIS & 203 & H-acceptor & 3.45 \\
\hline & $\mathrm{O}$ & GLY & 351 & H-acceptor & 3.23 \\
\hline & 6-ring & GLY & 378 & pi-H & 4.11 \\
\hline \multirow[t]{2}{*}{20} & $\mathrm{~S}$ & CYS & 188 & H-donor & 4.15 \\
\hline & 5-ring & HIS & 203 & pi-H & 3.61 \\
\hline 21 & 6-ring & HIS & 203 & pi-cation & 3.86 \\
\hline 22 & $\mathrm{O}$ & HIS & 203 & H-acceptor & 3.01 \\
\hline \multirow[t]{4}{*}{23} & $\mathrm{O}$ & GLY & 351 & H-acceptor & 3.42 \\
\hline & $\mathrm{O}$ & HIS & 203 & H-acceptor & 3.01 \\
\hline & 5-ring & GLU & 206 & pi-H & 4.27 \\
\hline & 5-ring & TRP & 213 & pi-H & 3.78 \\
\hline \multirow[t]{3}{*}{24} & $\mathrm{~S}$ & VAL & 187 & H-donor & 3.4 \\
\hline & $\mathrm{S}$ & GLY & 351 & H-donor & 3.95 \\
\hline & $\mathrm{O}$ & HIS & 203 & H-acceptor & 3.13 \\
\hline \multirow[t]{2}{*}{25} & $\mathrm{~N}$ & GLU & 206 & H-donor & 2.8 \\
\hline & 6-ring & LEU & 209 & pi-H & 4.26 \\
\hline \multirow[t]{2}{*}{26} & $\mathrm{~N}$ & VAL & 187 & H-donor & 2.98 \\
\hline & 6-ring & GLN & 350 & pi-H & 4.08 \\
\hline \multirow[t]{4}{*}{27} & $\mathrm{~S}$ & VAL & 187 & H-donor & 3.37 \\
\hline & $\mathrm{N}$ & HIS & 203 & H-acceptor & 3.53 \\
\hline & $\mathrm{N}$ & HIS & 203 & H-acceptor & 3.37 \\
\hline & 6-ring & ASN & 249 & pi-H & 3.61 \\
\hline 28 & $\mathrm{~N}$ & VAL & 187 & H-donor & 3.09 \\
\hline 29 & $S$ & HIS & 186 & H-donor & 3.9 \\
\hline
\end{tabular}

Table S6. Interaction report of each conformer of compound T5. Number of conformer, Atom of compound, Amino acid in TMPRSS2, Type of interaction and Distance in angstroms.

\begin{tabular}{|c|c|c|c|c|c|}
\hline \multirow{2}{*}{$\begin{array}{c}\text { Conformer } \\
1\end{array}$} & \multirow{2}{*}{$\begin{array}{l}\text { Ligand } \\
\mathrm{S} \\
\end{array}$} & \multicolumn{2}{|c|}{ Residues in TMPRSS2 } & \multirow{2}{*}{$\frac{\text { Interaction }}{\text { H-acceptor }}$} & \multirow{2}{*}{$\begin{array}{c}\text { Distance } \\
4.02\end{array}$} \\
\hline & & HIS & 203 & & \\
\hline & $\mathrm{S}$ & GLY & 378 & H-acceptor & 3.4 \\
\hline & $\mathrm{O}$ & $\mathrm{ASN}$ & 249 & H-acceptor & 3.13 \\
\hline & $\mathrm{O}$ & HIS & 203 & H-acceptor & 3.03 \\
\hline & 5-ring & HIS & 203 & pi-H & 3.81 \\
\hline 2 & $\mathrm{O}$ & HIS & 203 & H-acceptor & 3.04 \\
\hline \multirow[t]{3}{*}{3} & $\mathrm{~N}$ & VAL & 187 & H-donor & 3.08 \\
\hline & $\mathrm{S}$ & GLY & 351 & H-acceptor & 3.34 \\
\hline & 5-ring & CYS & 204 & pi-H & 3.8 \\
\hline \multirow[t]{3}{*}{4} & $\mathrm{~N}$ & VAL & 187 & H-donor & 3.2 \\
\hline & $\mathrm{S}$ & HIS & 203 & H-acceptor & 3.8 \\
\hline & $\mathrm{S}$ & TRP & 377 & H-acceptor & 3.85 \\
\hline \multirow[t]{3}{*}{5} & $\mathrm{~S}$ & HIS & 203 & H-acceptor & 3.73 \\
\hline & $\mathrm{S}$ & GLY & 378 & H-acceptor & 3.34 \\
\hline & $\mathrm{O}$ & HIS & 203 & H-acceptor & 2.99 \\
\hline 6 & $\mathrm{~S}$ & GLY & 351 & H-acceptor & 3.4 \\
\hline \multirow[t]{3}{*}{7} & $\mathrm{~N}$ & VAL & 187 & H-donor & 3.09 \\
\hline & $\mathrm{S}$ & GLY & 351 & H-acceptor & 3.34 \\
\hline & 5-ring & CYS & 204 & pi-H & 3.83 \\
\hline 8 & $\mathrm{~S}$ & GLY & 351 & H-acceptor & 3.39 \\
\hline 9 & 6-ring & GLN & 350 & pi-H & 3.96 \\
\hline 10 & 5-ring & HIS & 203 & pi-H & 3.73 \\
\hline 11 & 5-ring & CYS & 204 & pi-H & 4.15 \\
\hline \multirow[t]{2}{*}{12} & $\mathrm{~N}$ & VAL & 187 & H-donor & 3.11 \\
\hline & 5-ring & CYS & 204 & pi-H & 3.83 \\
\hline 13 & S & CYS & 204 & H-acceptor & 3.6 \\
\hline
\end{tabular}




\begin{tabular}{|c|c|c|c|c|c|}
\hline \multirow[t]{2}{*}{ Conformer } & \multirow{2}{*}{$\begin{array}{l}\text { Ligand } \\
\text { 6-ring }\end{array}$} & \multicolumn{2}{|c|}{ Residues in TMPRSS2 } & \multirow{2}{*}{$\frac{\text { Interaction }}{\mathrm{pi}-\mathrm{H}}$} & \multirow{2}{*}{$\begin{array}{c}\text { Distance } \\
4.25\end{array}$} \\
\hline & & GLN & 350 & & \\
\hline \multirow[t]{2}{*}{14} & $\mathrm{~S}$ & GLY & 351 & H-acceptor & 3.76 \\
\hline & 6-ring & HIS & 203 & pi-H & 3.66 \\
\hline \multirow[t]{3}{*}{15} & $\mathrm{~S}$ & HIS & 203 & H-acceptor & 3.68 \\
\hline & $\mathrm{S}$ & TRP & 377 & H-acceptor & 3.75 \\
\hline & 6-ring & VAL & 187 & pi-H & 3.86 \\
\hline \multirow[t]{4}{*}{16} & $\mathrm{~N}$ & VAL & 187 & H-donor & 3.27 \\
\hline & $\mathrm{S}$ & HIS & 203 & H-acceptor & 4.05 \\
\hline & $\mathrm{S}$ & CYS & 204 & H-acceptor & 3.94 \\
\hline & 5-ring & VAL & 187 & pi-H & 4.75 \\
\hline 17 & $S$ & GLY & 351 & H-acceptor & 3.39 \\
\hline \multirow[t]{6}{*}{18} & $\mathrm{~N}$ & SER & 348 & H-donor & 3.33 \\
\hline & $\mathrm{C}$ & SER & 348 & H-donor & 3.31 \\
\hline & $\mathrm{S}$ & HIS & 203 & H-acceptor & 3.62 \\
\hline & $\mathrm{S}$ & GLY & 378 & H-acceptor & 3.55 \\
\hline & $\mathrm{O}$ & LYS & 302 & $\mathrm{H}$-acceptor & 3.13 \\
\hline & 6-ring & HIS & 203 & pi-H & 4.67 \\
\hline \multirow[t]{2}{*}{19} & $\mathrm{O}$ & THR & 254 & H-acceptor & 3.28 \\
\hline & 5-ring & GLY & 378 & pi-H & 4.5 \\
\hline \multirow[t]{3}{*}{20} & $\mathrm{~S}$ & HIS & 203 & H-donor & 3.79 \\
\hline & $\mathrm{O}$ & HIS & 203 & H-acceptor & 3.02 \\
\hline & 6-ring & ASN & 249 & pi-H & 3.36 \\
\hline \multirow[t]{2}{*}{21} & $\mathrm{O}$ & THR & 305 & H-acceptor & 3.14 \\
\hline & 6-ring & VAL & 187 & pi-H & 4.63 \\
\hline \multirow[t]{3}{*}{22} & $\mathrm{C}$ & VAL & 187 & H-donor & 3.23 \\
\hline & $\mathrm{S}$ & HIS & 203 & H-acceptor & 4.05 \\
\hline & 6-ring & HIS & 203 & pi-cation & 4.57 \\
\hline \multirow[t]{2}{*}{23} & $\mathrm{~S}$ & HIS & 203 & H-acceptor & 3.82 \\
\hline & $S$ & GLY & 378 & H-acceptor & 3.35 \\
\hline \multirow[t]{3}{*}{24} & $\mathrm{~S}$ & HIS & 203 & H-acceptor & 3.73 \\
\hline & $\mathrm{S}$ & TRP & 377 & H-acceptor & 4.36 \\
\hline & $\mathrm{O}$ & GLY & 351 & H-acceptor & 3 \\
\hline \multirow[t]{2}{*}{25} & 5-ring & GLN & 350 & $\mathrm{pi}-\mathrm{H}$ & 4.31 \\
\hline & 5-ring & GLY & 351 & pi-H & 3.47 \\
\hline \multirow[t]{4}{*}{26} & $\mathrm{C}$ & SER & 348 & H-donor & 3.37 \\
\hline & $\mathrm{S}$ & HIS & 203 & H-acceptor & 3.2 \\
\hline & $\mathrm{S}$ & GLY & 378 & H-acceptor & 4.44 \\
\hline & 6-ring & HIS & 203 & pi-H & 3.86 \\
\hline \multirow[t]{3}{*}{27} & $\mathrm{O}$ & CYS & 381 & H-donor & 4.11 \\
\hline & $\mathrm{O}$ & LYS & 383 & H-acceptor & 3.09 \\
\hline & $\mathrm{O}$ & CYS & 381 & H-acceptor & 3.28 \\
\hline
\end{tabular}

Table S7. Interaction report of each conformer of compound T6. Number of conformer, Atom of compound, Amino acid in TMPRSS2, Type of interaction and Distance in angstroms.

\begin{tabular}{c|l|c|c|c|c} 
Conformer & Ligand & Residues in TMPRS2 & Interaction & Distance \\
\hline $\mathbf{1}$ & N & HIS & 186 & H-donor & 3.16 \\
\hline $\mathbf{2}$ & 6-ring & HIS & 203 & pi-H & 3.56 \\
\hline & N & SER & 348 & H-donor & 3 \\
\hline & 6-ring & VAL & 187 & pi-H & 4.58 \\
\hline $\mathbf{3}$ & 6-ring & GLY & 380 & pi-H & 3.86 \\
\hline $\mathbf{4}$ & S & GLU & 206 & H-donor & 4.14 \\
\hline $\mathbf{5}$ & 6-ring & HIS & 203 & pi-H & 3.64 \\
\hline $\mathbf{6}$ & N & HIS & 203 & pi-H & 3.64 \\
\hline & O & SER & 348 & H-donor & 2.92 \\
\hline & 6-ring & HIS & 203 & H-acceptor & 3.16 \\
\hline $\mathbf{7}$ & N & GLY & 380 & pi-H & 4.44 \\
\hline & O & HIS & 351 & H-donor & 3.08 \\
\hline & 6-ring & GLY & 380 & H-acceptor & 3.22 \\
\hline $\mathbf{8}$ & 6-ring & LEU & 209 & pi-H & 4.46 \\
\hline $\mathbf{9}$ & O & HIS & 203 & pi-H & 3.74 \\
\hline $\mathbf{1 0}$ & S & GLY & 378 & H-donor & 2.93 \\
\hline $\mathbf{1 1}$ & N & VAL & 187 & H-donor & 3.55 \\
\hline $\mathbf{1 2}$ & 6-ring & VAL & 187 & H-donor & 3.22 \\
\hline & 6-ring & HIS & 203 & pi-cation & 3.95 \\
\hline
\end{tabular}




\begin{tabular}{c|l|c|c|c|c} 
Conformer & Ligand & \multicolumn{2}{|c}{ Residues in TMPRSS2 } & Interaction & Distance \\
\hline $\mathbf{1 3}$ & N & GLU & 206 & H-donor & 2.93 \\
\hline $\mathbf{1 4}$ & 6-ring & HIS & 203 & pi-cation & 4.69 \\
\hline $\mathbf{1 5}$ & N & GLY & 351 & H-donor & 3.08 \\
\hline $\mathbf{1 6}$ & 6-ring & HIS & 203 & pi-cation & 3.96 \\
\hline $\mathbf{1 7}$ & 6-ring & HIS & 203 & pi-cation & 4.11 \\
\hline $\mathbf{1 8}$ & C & GLU & 206 & H-donor & 3.48 \\
\hline & O & HIS & 203 & H-acceptor & 3.03 \\
\hline & 6-ring & ASN & 249 & pi-H & 3.61 \\
\hline $\mathbf{1 9}$ & O & HIS & 203 & H-acceptor & 2.95 \\
\hline & O & HIS & 203 & H-acceptor & 3.19
\end{tabular}

Table S8. Interaction report of each conformer of compound T7. Number of conformer, Atom of compound,

Amino acid in TMPRSS2, Type of interaction and Distance in angstroms.

\begin{tabular}{|c|c|c|c|c|c|}
\hline \multirow{2}{*}{$\begin{array}{c}\text { Conformer } \\
1\end{array}$} & \multirow{2}{*}{$\frac{\text { Ligand }}{N}$} & \multicolumn{2}{|c|}{ Residues in TMPRSS2 } & \multirow{2}{*}{$\frac{\text { Interaction }}{\mathrm{H} \text {-acceptor }}$} & \multirow{2}{*}{$\begin{array}{r}\text { Distance } \\
3.37\end{array}$} \\
\hline & & HIS & 203 & & \\
\hline 2 & $\mathrm{C}$ & ASN & 249 & H-donor & 3.43 \\
\hline & $\mathrm{O}$ & ASN & 249 & H-acceptor & 3.2 \\
\hline \multirow[t]{2}{*}{3} & $\mathrm{~S}$ & HIS & 203 & H-donor & 3.55 \\
\hline & 5-ring & VAL & 187 & pi-H & 4.34 \\
\hline 4 & $\mathrm{C}$ & $\mathrm{ASN}$ & 249 & H-donor & 3.41 \\
\hline \multirow[t]{2}{*}{5} & $\mathrm{~N}$ & VAL & 187 & H-donor & 3.08 \\
\hline & $\mathrm{N}$ & GLY & 351 & H-acceptor & 3.07 \\
\hline 6 & $\mathrm{~N}$ & VAL & 187 & H-donor & 3.21 \\
\hline \multirow[t]{2}{*}{7} & $\mathrm{~S}$ & HIS & 203 & H-donor & 3.6 \\
\hline & $\mathrm{O}$ & HIS & 203 & H-acceptor & 2.92 \\
\hline \multirow[t]{2}{*}{8} & $\mathrm{~N}$ & VAL & 187 & H-donor & 3.07 \\
\hline & $\mathrm{N}$ & GLY & 351 & H-acceptor & 3.1 \\
\hline \multirow[t]{2}{*}{9} & $S$ & HIS & 203 & H-donor & 3.42 \\
\hline & $\mathrm{O}$ & GLY & 351 & H-acceptor & 3.15 \\
\hline \multirow[t]{4}{*}{10} & $S$ & HIS & 203 & H-donor & 3.67 \\
\hline & $\mathrm{O}$ & HIS & 203 & H-acceptor & 3.01 \\
\hline & $\mathrm{O}$ & GLY & 351 & H-acceptor & 3.33 \\
\hline & $\mathrm{O}$ & HIS & 203 & H-acceptor & 2.91 \\
\hline \multirow[t]{4}{*}{11} & $\mathrm{~N}$ & GLY & 351 & H-acceptor & 3.22 \\
\hline & $\mathrm{O}$ & HIS & 203 & H-acceptor & 3.13 \\
\hline & $\mathrm{C}$ & HIS & 186 & H-pi & 4.13 \\
\hline & 5-ring & GLY & 378 & pi-H & 4.06 \\
\hline 12 & $\mathrm{O}$ & HIS & 203 & H-acceptor & 3.11 \\
\hline \multirow[t]{3}{*}{13} & $\mathrm{~N}$ & GLU & 206 & H-donor & 2.86 \\
\hline & $\mathrm{O}$ & GLN & 350 & H-acceptor & 3.13 \\
\hline & 6-ring & GLN & 350 & pi-H & 4.14 \\
\hline \multirow[t]{2}{*}{14} & $\mathrm{C}$ & GLU & 206 & H-donor & 3.32 \\
\hline & $\mathrm{O}$ & HIS & 203 & H-acceptor & 3.12 \\
\hline \multirow[t]{2}{*}{15} & $S$ & SER & 376 & H-donor & 3.86 \\
\hline & $\mathrm{O}$ & TYR & 250 & H-acceptor & 3.04 \\
\hline 16 & $\mathrm{O}$ & HIS & 203 & H-acceptor & 2.86 \\
\hline 17 & $\mathrm{O}$ & HIS & 203 & H-acceptor & 2.97 \\
\hline \multirow[t]{3}{*}{18} & $\mathrm{O}$ & GLY & 351 & H-acceptor & 3.33 \\
\hline & $\mathrm{O}$ & GLY & 378 & H-acceptor & 3.43 \\
\hline & 5-ring & HIS & 203 & pi-H & 3.71 \\
\hline \multirow[t]{3}{*}{19} & $\mathrm{O}$ & GLY & 351 & H-acceptor & 3.08 \\
\hline & $\mathrm{C}$ & TRP & 377 & H-pi & 3.66 \\
\hline & 5-ring & HIS & 203 & pi-H & 3.63 \\
\hline \multirow[t]{3}{*}{20} & $\mathrm{~S}$ & GLY & 351 & H-donor & 3.79 \\
\hline & $\mathrm{O}$ & GLN & 350 & H-acceptor & 3.33 \\
\hline & 6-ring & ASN & 249 & pi-H & 4.04 \\
\hline 21 & $\mathrm{O}$ & LYS & 302 & H-acceptor & 3.16 \\
\hline \multirow[t]{2}{*}{22} & $\mathrm{~S}$ & GLY & 351 & H-donor & 3.61 \\
\hline & $\mathrm{O}$ & LYS & 302 & H-acceptor & 2.93 \\
\hline 23 & $\mathrm{O}$ & LYS & 302 & H-acceptor & 3.11 \\
\hline \multirow[t]{2}{*}{24} & $\mathrm{~N}$ & GLU & 206 & H-donor & 3.33 \\
\hline & $\mathrm{N}$ & GLU & 206 & H-donor & 3.15 \\
\hline
\end{tabular}

Table S9. Interaction report of each conformer of compound T8. Number of conformer, Atom of compound, Amino acid in TMPRSS2, Type of interaction and Distance in angstroms 


\begin{tabular}{|c|c|c|c|c|c|}
\hline \multirow{2}{*}{$\frac{\text { Conformer }}{1}$} & \multirow{2}{*}{$\begin{array}{l}\text { Ligand } \\
\mathrm{S} \\
\end{array}$} & \multicolumn{2}{|c|}{ Residues in TMPRSS2 } & \multirow{2}{*}{$\begin{array}{r}\text { Interaction } \\
\text { H-donor }\end{array}$} & \multirow{2}{*}{$\begin{array}{r}\text { Distance } \\
3.64 \\
\end{array}$} \\
\hline & & GLU & 301 & & \\
\hline & $\mathrm{C}$ & CYS & 381 & H-donor & 3.8 \\
\hline & $\mathrm{O}$ & LYS & 383 & H-acceptor & 3.58 \\
\hline & $\mathrm{O}$ & CYS & 381 & H-acceptor & 3.05 \\
\hline & 5-ring & HIS & 203 & pi-cation & 3.51 \\
\hline & 5-ring & GLY & 303 & pi-H & 4.14 \\
\hline \multirow[t]{4}{*}{2} & $\mathrm{~S}$ & LYS & 302 & H-acceptor & 4.01 \\
\hline & $\mathrm{S}$ & GLY & 303 & H-acceptor & 3.85 \\
\hline & $\mathrm{O}$ & CYS & 381 & H-acceptor & 3.44 \\
\hline & $\mathrm{O}$ & LYS & 383 & H-acceptor & 3.18 \\
\hline \multirow[t]{6}{*}{3} & $\mathrm{~S}$ & HIS & 203 & H-donor & 3.09 \\
\hline & $\mathrm{S}$ & VAL & 205 & H-donor & 3.86 \\
\hline & $\mathrm{S}$ & ASN & 249 & H-donor & 3.47 \\
\hline & $\mathrm{S}$ & CYS & 204 & H-acceptor & 3.82 \\
\hline & $\mathrm{S}$ & TRP & 377 & H-acceptor & 4.26 \\
\hline & $\mathrm{O}$ & HIS & 203 & H-acceptor & 3.28 \\
\hline \multirow[t]{3}{*}{4} & $\mathrm{~S}$ & GLY & 351 & H-acceptor & 3.45 \\
\hline & $\mathrm{O}$ & GLN & 350 & H-acceptor & 3.18 \\
\hline & 5-ring & CYS & 381 & pi-H & 4.34 \\
\hline \multirow[t]{4}{*}{5} & $\mathrm{~S}$ & HIS & 203 & H-acceptor & 4 \\
\hline & $\mathrm{S}$ & GLY & 380 & H-acceptor & 3.91 \\
\hline & $\mathrm{O}$ & HIS & 203 & H-acceptor & 3.08 \\
\hline & $\mathrm{O}$ & HIS & 203 & H-acceptor & 3.12 \\
\hline \multirow[t]{2}{*}{6} & $\mathrm{O}$ & GLY & 351 & H-acceptor & 3.11 \\
\hline & 6-ring & LEU & 209 & pi-H & 3.77 \\
\hline \multirow[t]{3}{*}{7} & $\mathrm{~S}$ & GLY & 378 & H-donor & 3.76 \\
\hline & $\mathrm{O}$ & HIS & 203 & H-acceptor & 3.02 \\
\hline & 6-ring & LEU & 209 & pi-H & 3.88 \\
\hline \multirow[t]{4}{*}{8} & $\mathrm{~S}$ & GLU & 206 & H-donor & 3.45 \\
\hline & $\mathrm{O}$ & HIS & 203 & H-acceptor & 3.24 \\
\hline & 5-ring & VAL & 187 & pi-H & 4.57 \\
\hline & 5-ring & CYS & 204 & pi-H & 4.43 \\
\hline \multirow[t]{3}{*}{9} & $\mathrm{~S}$ & HIS & 203 & H-donor & 3.25 \\
\hline & $\mathrm{S}$ & CYS & 204 & H-acceptor & 3.73 \\
\hline & $\mathrm{S}$ & TRP & 377 & H-acceptor & 4.27 \\
\hline 10 & 5-ring & GLY & 351 & pi-H & 4.04 \\
\hline 11 & $\mathrm{~N}$ & GLY & 378 & H-donor & 3.01 \\
\hline & $\mathrm{S}$ & CYS & 204 & H-acceptor & 3.95 \\
\hline & $\mathrm{O}$ & HIS & 203 & H-acceptor & 3.29 \\
\hline 12 & $\mathrm{~N}$ & SER & 379 & H-donor & 3.27 \\
\hline & $\mathrm{O}$ & HIS & 203 & $\mathrm{H}$-acceptor & 3.23 \\
\hline & 6-ring & VAL & 187 & pi-H & 4.14 \\
\hline 13 & $\mathrm{~N}$ & CYS & 349 & H-donor & 2.99 \\
\hline & $\mathrm{O}$ & LYS & 383 & H-acceptor & 3 \\
\hline 14 & $\mathrm{~N}$ & CYS & 349 & H-donor & 2.98 \\
\hline & $\mathrm{S}$ & LYS & 302 & H-acceptor & 3.51 \\
\hline & $\mathrm{S}$ & GLY & 303 & H-acceptor & 4.15 \\
\hline & $\mathrm{O}$ & HIS & 203 & H-acceptor & 3.15 \\
\hline 15 & $\mathrm{~S}$ & GLY & 351 & H-acceptor & 4.49 \\
\hline & $\mathrm{O}$ & HIS & 203 & H-acceptor & 2.9 \\
\hline 16 & $\mathrm{~N}$ & GLY & 378 & H-donor & 3.19 \\
\hline & $\mathrm{S}$ & GLY & 351 & H-acceptor & 3.36 \\
\hline & $\mathrm{O}$ & HIS & 203 & H-acceptor & 2.97 \\
\hline & $\mathrm{O}$ & HIS & 203 & H-acceptor & 2.99 \\
\hline & 6-ring & LYS & 383 & $\mathrm{pi}-\mathrm{H}$ & 3.63 \\
\hline 17 & $\mathrm{~S}$ & GLN & 350 & H-acceptor & 3.86 \\
\hline & $\mathrm{O}$ & HIS & 203 & $\mathrm{H}$-acceptor & 3.02 \\
\hline & 5-ring & HIS & 203 & pi-H & 3.64 \\
\hline 18 & $\mathrm{~N}$ & SER & 379 & H-donor & 3.12 \\
\hline & $\mathrm{S}$ & HIS & 203 & H-acceptor & 3.22 \\
\hline & $\mathrm{O}$ & GLY & 351 & H-acceptor & 3 \\
\hline 19 & $\mathrm{~S}$ & GLY & 351 & H-acceptor & 3.43 \\
\hline & 6-ring & CYS & 204 & pi-H & 4.62 \\
\hline 20 & $\mathrm{~S}$ & LYS & 383 & H-acceptor & 3.77 \\
\hline & $\mathrm{O}$ & LYS & 383 & H-acceptor & 2.91 \\
\hline & 6-ring & HIS & 203 & pi-H & 3.84 \\
\hline
\end{tabular}




\begin{tabular}{c|l|c|c|c|c} 
Conformer & Ligand & \multicolumn{2}{|c}{ Residues in TMPRSS2 } & Interaction & Distance \\
\hline $\mathbf{2 1}$ & S & SER & 379 & H-donor & 3.86 \\
\hline & S & HIS & 203 & H-acceptor & 3.86 \\
\hline $\mathbf{2 2}$ & S & HIS & 203 & H-acceptor & 4.34 \\
\hline & O & HIS & 203 & H-acceptor & 3.1 \\
\hline $\mathbf{2 3}$ & O & HIS & 203 & H-acceptor & 3.46 \\
\hline & O & HIS & 203 & H-acceptor & 3.05 \\
\hline & 6-ring & ASP & 329 & pi-H & 4.82 \\
\hline & 5-ring & SER & 379 & pi-H & 4.64 \\
\hline S4 & S & HIS & 203 & H-acceptor & 3.86 \\
\hline & S & LYS & 302 & H-acceptor & 3.38 \\
\hline & O & GLY & 351 & H-acceptor & 2.93 \\
\hline & 5-ring & VAL & 187 & pi-H & 4.11 \\
\hline & S & GLY & 351 & H-acceptor & 3.47 \\
\hline & S & THR & 305 & H-acceptor & 3.47 \\
\hline & O & LYS & 302 & H-acceptor & 3.26 \\
\hline & O & GLY & 351 & H-acceptor & 3.07 \\
\hline & 6-ring & HIS & 203 & pi-cation & 4.78 \\
\hline & S & CYS & 381 & H-donor & 4.32 \\
\hline & S & CYS & 381 & H-acceptor & 3.89 \\
\hline $\mathbf{2 6}$ & S & GLY & 351 & H-acceptor & 3.43 \\
\hline & O & GLY & 351 & H-acceptor & 2.83 \\
\hline & S & GLU & 206 & H-donor & 3.42 \\
\hline & S & HIS & 203 & H-acceptor & 3.43 \\
\hline & O & CYS & 381 & H-donor & 3.18
\end{tabular}

Table S10. Interaction report of each conformer of compound T9. Number of conformer, Atom of compound,

Amino acid in TMPRSS2, Type of interaction and Distance in angstroms.

\begin{tabular}{|c|c|c|c|c|c|}
\hline \multirow{2}{*}{$\begin{array}{c}\text { Conformer } \\
1 \\
\end{array}$} & \multirow{2}{*}{$\begin{array}{l}\text { Ligand } \\
\mathrm{O} \\
\end{array}$} & \multicolumn{2}{|c|}{ Residues in TMPRSS2 } & \multirow{2}{*}{$\frac{\text { Interaction }}{\text { H-acceptor }}$} & \multirow{2}{*}{$\begin{array}{c}\text { Distance } \\
3.13\end{array}$} \\
\hline & & GLY & 351 & & \\
\hline 2 & $\mathrm{~N}$ & GLU & 206 & H-donor & 2.91 \\
\hline \multirow[t]{3}{*}{3} & $\mathrm{~S}$ & HIS & 203 & H-donor & 3.64 \\
\hline & $\mathrm{O}$ & HIS & 203 & H-acceptor & 3.32 \\
\hline & 6-ring & VAL & 187 & pi-H & 4.05 \\
\hline \multirow[t]{3}{*}{4} & $\mathrm{~N}$ & HIS & 203 & H-acceptor & 3.07 \\
\hline & $\mathrm{O}$ & GLY & 351 & H-acceptor & 2.96 \\
\hline & 6-ring & CYS & 204 & pi-H & 3.99 \\
\hline \multirow[t]{6}{*}{5} & $\mathrm{~N}$ & VAL & 187 & H-donor & 2.81 \\
\hline & $\mathrm{S}$ & VAL & 187 & H-donor & 3.25 \\
\hline & $\mathrm{N}$ & HIS & 203 & H-acceptor & 3.39 \\
\hline & $\mathrm{N}$ & HIS & 203 & H-acceptor & 3.47 \\
\hline & 5-ring & CYS & 204 & pi-H & 4.14 \\
\hline & 5-ring & GLY & 351 & pi-H & 3.4 \\
\hline 6 & $\mathrm{O}$ & GLY & 378 & H-acceptor & 2.88 \\
\hline \multirow[t]{3}{*}{7} & $\mathrm{~S}$ & GLY & 351 & H-donor & 3.62 \\
\hline & $\mathrm{N}$ & HIS & 203 & H-acceptor & 3.27 \\
\hline & 6-ring & CYS & 204 & pi-H & 4.04 \\
\hline \multirow[t]{3}{*}{8} & $\mathrm{~S}$ & SER & 376 & H-donor & 4.02 \\
\hline & $\mathrm{N}$ & GLY & 351 & H-acceptor & 3.05 \\
\hline & 6-ring & CYS & 381 & pi-H & 4.48 \\
\hline \multirow[t]{2}{*}{9} & $\mathrm{~S}$ & SER & 348 & H-donor & 3.33 \\
\hline & $\mathrm{O}$ & HIS & 203 & H-acceptor & 3.22 \\
\hline 10 & 5-ring & CYS & 204 & pi-H & 4.03 \\
\hline 11 & $\mathrm{~S}$ & HIS & 203 & H-donor & 3.15 \\
\hline 12 & $\mathrm{~N}$ & GLU & 206 & H-donor & 3.09 \\
\hline \multirow[t]{3}{*}{13} & $\mathrm{~N}$ & CYS & 349 & H-donor & 2.92 \\
\hline & $\mathrm{S}$ & CYS & 349 & H-donor & 3.67 \\
\hline & 5-ring & GLY & 380 & pi-H & 3.74 \\
\hline \multirow[t]{3}{*}{14} & $\mathrm{~N}$ & GLY & 351 & H-acceptor & 3.35 \\
\hline & $\mathrm{O}$ & HIS & 203 & H-acceptor & 3.05 \\
\hline & 5-ring & GLY & 380 & pi-H & 3.99 \\
\hline \multirow[t]{4}{*}{15} & $\mathrm{~S}$ & VAL & 187 & H-donor & 3.36 \\
\hline & $\mathrm{S}$ & GLY & 351 & H-donor & 3.76 \\
\hline & 5-ring & HIS & 203 & pi-H & 3.59 \\
\hline & 6-ring & HIS & 203 & pi-cation & 3.85 \\
\hline \multirow[t]{2}{*}{16} & $\mathrm{~S}$ & VAL & 187 & H-donor & 3.33 \\
\hline & $\mathrm{S}$ & GLY & 351 & H-donor & 3.8 \\
\hline
\end{tabular}




\begin{tabular}{c|l|c|c|c|c} 
Conformer & Ligand & \multicolumn{2}{c}{ Residues in TMPRS2 } & Interaction & Distance \\
\hline & 5-ring & HIS & 203 & pi-H & 3.58 \\
\hline & 6-ring & HIS & 203 & pi-cation & 3.77 \\
\hline $\mathbf{1 7}$ & N & VAL & 187 & H-donor & 2.88 \\
\hline & 5-ring & GLY & 351 & pi-H & 3.54 \\
\hline $\mathbf{1 8}$ & N & VAL & 187 & H-donor & 2.9 \\
\hline & 5-ring & GLY & 351 & pi-H & 3.46 \\
\hline $\mathbf{1 9}$ & S & GLU & 206 & H-donor & 3.33 \\
\hline & C & TRP & 215 & H-pi & 4.63 \\
\hline $\mathbf{2 0}$ & N & ASN & 249 & H-acceptor & 3.07 \\
\hline $\mathbf{2 1}$ & O & HIS & 203 & H-acceptor & 3.31 \\
\hline & 6-ring & CYS & 381 & pi-H & 4.19 \\
\hline $\mathbf{2 2}$ & S & HIS & 203 & H-acceptor & 3.38 \\
\hline & 5-ring & ASN & 249 & pi-H & 4.08
\end{tabular}

Table S11. Interaction report of each conformer of compound T10. Number of conformer, Atom of compound, Amino acid in TMPRSS2, Type of interaction and Distance in angstroms.

\begin{tabular}{|c|c|c|c|c|c|}
\hline \multirow{2}{*}{$\begin{array}{c}\text { Conformer } \\
1 \\
\end{array}$} & \multirow{2}{*}{$\begin{array}{l}\text { Ligand } \\
\mathrm{N}\end{array}$} & \multicolumn{2}{|c|}{ Residues in TMPRSS2 } & \multirow{2}{*}{$\begin{array}{c}\text { Interaction } \\
\mathrm{H} \text {-donor }\end{array}$} & \multirow{2}{*}{$\begin{array}{c}\text { Distance } \\
3.15\end{array}$} \\
\hline & & CYS & 349 & & \\
\hline & $\mathrm{O}$ & HIS & 203 & H-acceptor & 3.07 \\
\hline & $\mathrm{C}$ & HIS & 186 & H-pi & 3.67 \\
\hline \multirow[t]{3}{*}{2} & $\mathrm{O}$ & GLY & 351 & H-acceptor & 3.23 \\
\hline & $\mathrm{O}$ & HIS & 203 & H-acceptor & 3.08 \\
\hline & 6-ring & HIS & 203 & pi-cation & 4.83 \\
\hline 3 & 6-ring & HIS & 203 & pi-cation & 4.87 \\
\hline \multirow[t]{2}{*}{4} & $\mathrm{~S}$ & HIS & 203 & H-donor & 3.73 \\
\hline & $\mathrm{O}$ & HIS & 203 & H-acceptor & 3.26 \\
\hline 5 & $\mathrm{O}$ & HIS & 203 & H-acceptor & 2.99 \\
\hline \multirow[t]{2}{*}{6} & $\mathrm{O}$ & GLY & 351 & H-acceptor & 3.06 \\
\hline & $\mathrm{O}$ & HIS & 203 & H-acceptor & 2.98 \\
\hline \multirow[t]{2}{*}{7} & $\mathrm{~S}$ & HIS & 203 & H-donor & 3.88 \\
\hline & 5-ring & VAL & 187 & pi-H & 4.26 \\
\hline 8 & 5-ring & GLN & 350 & pi-H & 4 \\
\hline 9 & $\mathrm{~N}$ & GLU & 206 & H-donor & 2.94 \\
\hline \multirow[t]{3}{*}{10} & $\mathrm{~N}$ & CYS & 349 & H-donor & 3.04 \\
\hline & $\mathrm{N}$ & GLY & 351 & H-acceptor & 3.07 \\
\hline & $\mathrm{O}$ & HIS & 203 & H-acceptor & 3.1 \\
\hline \multirow[t]{2}{*}{11} & $\mathrm{~N}$ & GLU & 206 & H-donor & 3.17 \\
\hline & 5-ring & VAL & 187 & pi-H & 4.3 \\
\hline \multirow[t]{4}{*}{12} & $\mathrm{~N}$ & VAL & 187 & H-donor & 2.85 \\
\hline & $\mathrm{N}$ & GLU & 206 & H-donor & 3 \\
\hline & $\mathrm{O}$ & ASN & 249 & H-acceptor & 3.21 \\
\hline & 5-ring & GLY & 351 & pi-H & 3.55 \\
\hline \multirow[t]{3}{*}{13} & $\mathrm{~S}$ & GLU & 206 & H-donor & 3.43 \\
\hline & $\mathrm{N}$ & HIS & 203 & H-acceptor & 3.11 \\
\hline & 6-ring & HIS & 203 & pi-cation & 3.69 \\
\hline \multirow[t]{3}{*}{14} & $\mathrm{~N}$ & GLU & 206 & H-donor & 2.92 \\
\hline & $\mathrm{S}$ & GLU & 206 & H-donor & 3.53 \\
\hline & 5-ring & HIS & 203 & pi-cation & 3.48 \\
\hline \multirow[t]{2}{*}{15} & $\mathrm{~S}$ & ASN & 249 & H-donor & 3.76 \\
\hline & 5-ring & HIS & 203 & pi-cation & 3.55 \\
\hline \multirow[t]{4}{*}{16} & $\mathrm{O}$ & GLY & 303 & H-acceptor & 3.17 \\
\hline & $\mathrm{O}$ & GLN & 350 & H-acceptor & 3.17 \\
\hline & $\mathrm{O}$ & HIS & 203 & H-acceptor & 3.38 \\
\hline & 5-ring & VAL & 187 & pi-H & 4.35 \\
\hline 17 & 5-ring & GLY & 378 & pi-H & 4.62 \\
\hline 18 & $\mathrm{~N}$ & GLU & 206 & H-donor & 2.88 \\
\hline 19 & $\mathrm{O}$ & GLY & 351 & H-acceptor & 3.1 \\
\hline 20 & $\mathrm{~N}$ & GLU & 206 & H-donor & 2.96 \\
\hline \multirow[t]{2}{*}{21} & $\mathrm{O}$ & HIS & 203 & H-acceptor & 3.37 \\
\hline & $\mathrm{O}$ & GLY & 351 & H-acceptor & 2.9 \\
\hline \multirow[t]{2}{*}{22} & $\mathrm{O}$ & HIS & 203 & H-acceptor & 2.93 \\
\hline & 6-ring & VAL & 187 & pi-H & 4.6 \\
\hline \multirow[t]{2}{*}{23} & $\mathrm{~S}$ & VAL & 187 & H-donor & 3.8 \\
\hline & $S$ & GLY & 351 & H-donor & 3.99 \\
\hline 24 & S & HIS & 186 & H-donor & 4.29 \\
\hline 25 & $\mathrm{~N}$ & GLU & 206 & H-donor & 3.21 \\
\hline
\end{tabular}




\begin{tabular}{l|l|c|c|c|c} 
Conformer & Ligand & \multicolumn{2}{|c|}{ Residues in TMPRSS2 } & Interaction & Distance \\
\hline & C & GLU & 206 & H-donor & 3.59 \\
\hline & O & HIS & 203 & H-acceptor & 3.64
\end{tabular}

Table S12. Interaction report of each conformer of Daclatasvir. Number of conformer, Atom of compound, Amino acid in TMPRSS2, Type of interaction and Distance in angstroms.

\begin{tabular}{|c|c|c|c|c|c|}
\hline \multirow{2}{*}{$\begin{array}{c}\text { Conformer } \\
1 \\
\end{array}$} & \multirow{2}{*}{$\begin{array}{l}\text { Ligand } \\
\mathrm{N} \\
\end{array}$} & \multicolumn{2}{|c|}{ Residues in TMPRSS2 } & \multirow{2}{*}{$\begin{array}{c}\text { Interaction } \\
\text { H-donor } \\
\end{array}$} & \multirow{2}{*}{$\begin{array}{c}\text { Distance } \\
2.99 \\
\end{array}$} \\
\hline & & CYS & 349 & & \\
\hline & $\mathrm{O}$ & GLY & 351 & H-acceptor & 3.59 \\
\hline 2 & 6-ring & VAL & 187 & pi-H & 3.96 \\
\hline 3 & 5-ring & CYS & 381 & pi-H & 4.18 \\
\hline \multirow[t]{3}{*}{4} & $\mathrm{~N}$ & ASN & 249 & H-donor & 3.1 \\
\hline & $\mathrm{O}$ & HIS & 203 & H-acceptor & 2.93 \\
\hline & 5-ring & CYS & 381 & pi-H & 4.35 \\
\hline \multirow[t]{2}{*}{5} & $\mathrm{O}$ & HIS & 203 & H-acceptor & 2.89 \\
\hline & 5-ring & CYS & 381 & pi-H & 4.38 \\
\hline 6 & $\mathrm{~N}$ & CYS & 349 & H-donor & 3.28 \\
\hline \multirow[t]{2}{*}{7} & $\mathrm{~N}$ & GLU & 206 & H-donor & 3.29 \\
\hline & 5-ring & CYS & 381 & pi-H & 4.36 \\
\hline 8 & 5-ring & CYS & 381 & pi-H & 4.28 \\
\hline 9 & $\mathrm{~N}$ & GLU & 206 & H-donor & 3.28 \\
\hline 10 & 5-ring & CYS & 381 & pi-H & 4.35 \\
\hline \multirow[t]{5}{*}{11} & $\mathrm{O}$ & CYS & 381 & H-donor & 4.1 \\
\hline & $\mathrm{N}$ & GLU & 206 & H-donor & 3.38 \\
\hline & $\mathrm{N}$ & GLU & 206 & H-donor & 3.46 \\
\hline & $\mathrm{N}$ & CYS & 381 & H-donor & 3.78 \\
\hline & $\mathrm{O}$ & CYS & 381 & H-acceptor & 3.48 \\
\hline 12 & 5-ring & HIS & 203 & pi-cation & 3.88 \\
\hline \multirow[t]{2}{*}{13} & 5-ring & LYS & 302 & pi-cation & 3.83 \\
\hline & 6-ring & GLN & 350 & pi-H & 3.83 \\
\hline 14 & $\mathrm{~N}$ & GLU & 206 & H-donor & 3.24 \\
\hline \multirow[t]{2}{*}{15} & $\mathrm{~N}$ & GLY & 351 & H-acceptor & 3.08 \\
\hline & 6-ring & HIS & 203 & pi-cation & 3.78 \\
\hline \multirow[t]{4}{*}{16} & $\mathrm{O}$ & GLY & 303 & H-acceptor & 3.37 \\
\hline & $\mathrm{O}$ & HIS & 203 & H-acceptor & 3.28 \\
\hline & $\mathrm{N}$ & LYS & 383 & H-acceptor & 3.02 \\
\hline & 5-ring & CYS & 381 & pi-H & 4.23 \\
\hline 16 & $\mathrm{O}$ & GLY & 378 & H-acceptor & 3.06 \\
\hline \multirow[t]{2}{*}{17} & $\mathrm{~N}$ & GLU & 206 & H-donor & 3.13 \\
\hline & $\mathrm{O}$ & LYS & 383 & H-acceptor & 3.24 \\
\hline \multirow[t]{2}{*}{18} & $\mathrm{O}$ & LYS & 383 & H-acceptor & 2.91 \\
\hline & $\mathrm{N}$ & GLY & 303 & H-acceptor & 3.35 \\
\hline \multirow[t]{2}{*}{19} & $\mathrm{~N}$ & GLU & 206 & H-donor & 3.34 \\
\hline & $\mathrm{O}$ & LYS & 383 & H-acceptor & 2.98 \\
\hline 20 & $\mathrm{~N}$ & GLU & 206 & H-donor & 3.41 \\
\hline 21 & 6-ring & GLN & 350 & pi-H & 4.05 \\
\hline
\end{tabular}

Table S13. Interaction report of each conformer of Ombitasvir. Number of conformer, Atom of compound, Amino acid in TMPRSS2, Type of interaction and Distance in angstroms.

\begin{tabular}{c|l|c|c|c|c} 
Conformer & Ligand & \multicolumn{2}{|c}{ Residues in TMPRSS2 } & Interaction & Distance \\
\hline $\mathbf{1}$ & 6-ring & HIS & 203 & pi-cation & 3.75 \\
\hline $\mathbf{2}$ & 6-ring & HIS & 203 & pi-cation & 4.09 \\
\hline $\mathbf{3}$ & N & GLU & 206 & H-donor & 3.11 \\
\hline & O & CYS & 381 & H-donor & 3.38 \\
\hline $\mathbf{4}$ & O & SER & 379 & H-acceptor & 3 \\
\hline & O & ARG & 386 & H-acceptor & 3.16 \\
\hline & O & ARG & 386 & H-acceptor & 2.91 \\
\hline & O & HIS & 203 & H-acceptor & 3.05 \\
\hline $\mathbf{5}$ & O & GLY & 351 & H-acceptor & 3.12 \\
\hline $\mathbf{6}$ & O & ARG & 386 & H-acceptor & 3.08 \\
\hline $\mathbf{7}$ & O & HIS & 203 & H-acceptor & 2.91 \\
\hline $\mathbf{8}$ & O & HIS & 203 & H-acceptor & 3.52 \\
\hline $\mathbf{9}$ & N & SER & 379 & H-donor & 3.19 \\
\hline $\mathbf{1 0}$ & O & HIS & 203 & H-acceptor & 3.2 \\
\hline & O & CYS & 381 & H-donor & 3.82 \\
\hline & & LYS & 383 & H-acceptor & 3.19
\end{tabular}




\begin{tabular}{|c|c|c|c|c|c|}
\hline \multirow{2}{*}{$\begin{array}{c}\text { Conformer } \\
11\end{array}$} & \multirow{2}{*}{$\begin{array}{l}\text { Ligand } \\
\mathrm{C}\end{array}$} & \multicolumn{2}{|c|}{ Residues in TMPRSS2 } & \multirow{2}{*}{$\begin{array}{c}\text { Interaction } \\
\text { H-pi }\end{array}$} & \multirow{2}{*}{$\begin{array}{c}\text { Distance } \\
4.11\end{array}$} \\
\hline & & TRP & 377 & & \\
\hline 12 & $\mathrm{~N}$ & SER & 379 & H-donor & 3.4 \\
\hline \multirow[t]{3}{*}{13} & $\mathrm{~N}$ & GLU & 206 & H-donor & 3.29 \\
\hline & $\mathrm{O}$ & HIS & 203 & H-acceptor & 2.91 \\
\hline & 6-ring & GLN & 350 & pi-H & 3.66 \\
\hline \multirow[t]{2}{*}{14} & $\mathrm{~N}$ & GLU & 206 & H-donor & 3.42 \\
\hline & $\mathrm{O}$ & LYS & 383 & H-acceptor & 2.95 \\
\hline 15 & $\mathrm{O}$ & GLY & 303 & H-acceptor & 3.39 \\
\hline 16 & $\mathrm{O}$ & ARG & 386 & H-acceptor & 3.29 \\
\hline \multirow[t]{4}{*}{17} & $\mathrm{~N}$ & GLU & 206 & $\mathrm{H}$-donor & 3.54 \\
\hline & $\mathrm{N}$ & GLU & 206 & H-donor & 3.17 \\
\hline & $\mathrm{O}$ & HIS & 203 & H-acceptor & 3.22 \\
\hline & $\mathrm{O}$ & ASN & 249 & H-acceptor & 3.22 \\
\hline \multirow[t]{4}{*}{18} & $\mathrm{~N}$ & GLU & 206 & H-donor & 3.4 \\
\hline & $\mathrm{N}$ & GLU & 206 & H-donor & 3.15 \\
\hline & $\mathrm{O}$ & HIS & 203 & H-acceptor & 3.1 \\
\hline & $\mathrm{O}$ & ASN & 249 & H-acceptor & 3.21 \\
\hline 19 & $\mathrm{O}$ & ASN & 249 & H-acceptor & 3.22 \\
\hline \multirow[t]{3}{*}{20} & $\mathrm{O}$ & TYR & 250 & H-acceptor & 3.12 \\
\hline & $\mathrm{O}$ & LYS & 383 & H-acceptor & 3.26 \\
\hline & $\mathrm{O}$ & GLY & 303 & H-acceptor & 3.24 \\
\hline \multirow[t]{2}{*}{21} & $\mathrm{O}$ & ASN & 249 & H-acceptor & 3.43 \\
\hline & $\mathrm{O}$ & ARG & 386 & H-acceptor & 2.96 \\
\hline \multirow[t]{2}{*}{22} & $\mathrm{O}$ & LYS & 383 & H-acceptor & 2.94 \\
\hline & 6-ring & GLN & 350 & pi-H & 3.64 \\
\hline 23 & $\mathrm{O}$ & ARG & 386 & H-acceptor & 2.96 \\
\hline \multirow[t]{3}{*}{24} & $\mathrm{~N}$ & GLU & 206 & H-donor & 3.15 \\
\hline & $\mathrm{O}$ & LYS & 302 & H-acceptor & 2.94 \\
\hline & $\mathrm{O}$ & HIS & 203 & H-acceptor & 3.11 \\
\hline 25 & $\mathrm{O}$ & ARG & 386 & H-acceptor & 2.95 \\
\hline
\end{tabular}

Table S14. Interaction report of each conformer of Camostat. Number of conformer, Atom of compound, Amino acid in TMPRSS2, Type of interaction and Distance in angstroms.

\begin{tabular}{|c|c|c|c|c|c|}
\hline \multirow{2}{*}{$\begin{array}{c}\text { Conformer } \\
1 \\
\end{array}$} & \multirow{2}{*}{$\begin{array}{l}\text { Ligand } \\
\mathrm{N} \\
\end{array}$} & \multicolumn{2}{|c|}{ Residues in TMPRSS2 } & \multirow{2}{*}{$\begin{array}{c}\text { Interaction } \\
\text { H-donor }\end{array}$} & \multirow{2}{*}{$\begin{array}{c}\text { Distance } \\
2.8\end{array}$} \\
\hline & & SER & 379 & & \\
\hline & $\mathrm{O}$ & HIS & 203 & H-acceptor & 3.19 \\
\hline \multirow[t]{4}{*}{2} & $\mathrm{O}$ & HIS & 203 & H-acceptor & 3.42 \\
\hline & $\mathrm{N}$ & GLU & 206 & ionic & 3.5 \\
\hline & $\mathrm{N}$ & GLU & 206 & ionic & 3.5 \\
\hline & $\mathrm{N}$ & GLU & 206 & ionic & 3.83 \\
\hline \multirow[t]{5}{*}{3} & $\mathrm{O}$ & HIS & 203 & H-acceptor & 3.37 \\
\hline & $\mathrm{O}$ & HIS & 203 & H-acceptor & 3.07 \\
\hline & $\mathrm{N}$ & GLU & 206 & ionic & 3.83 \\
\hline & $\mathrm{N}$ & GLU & 206 & ionic & 3.53 \\
\hline & $\mathrm{N}$ & GLU & 206 & ionic & 3.87 \\
\hline \multirow[t]{5}{*}{4} & $\mathrm{O}$ & GLY & 351 & H-acceptor & 3.1 \\
\hline & $\mathrm{N}$ & GLU & 206 & ionic & 3.5 \\
\hline & $\mathrm{N}$ & GLU & 206 & ionic & 3.37 \\
\hline & $\mathrm{N}$ & GLU & 206 & ionic & 3.98 \\
\hline & $\mathrm{N}$ & GLU & 206 & ionic & 3.72 \\
\hline \multirow[t]{4}{*}{5} & $\mathrm{~N}$ & GLU & 206 & H-donor & 2.99 \\
\hline & $\mathrm{N}$ & GLU & 206 & ionic & 2.99 \\
\hline & $\mathrm{N}$ & GLU & 206 & ionic & 3.92 \\
\hline & $\mathrm{N}$ & $\overline{\text { GLU }}$ & 206 & ionic & 3.63 \\
\hline \multirow[t]{5}{*}{6} & $\mathrm{O}$ & HIS & 203 & H-acceptor & 3.39 \\
\hline & $\mathrm{N}$ & GLU & 206 & ionic & 3.66 \\
\hline & $\mathrm{N}$ & GLU & 206 & ionic & 3.65 \\
\hline & $\mathrm{N}$ & GLU & 206 & ionic & 3.97 \\
\hline & $\mathrm{N}$ & GLU & 206 & ionic & 3.16 \\
\hline \multirow[t]{4}{*}{7} & $\mathrm{~N}$ & GLU & 206 & H-donor & 3.13 \\
\hline & $\mathrm{O}$ & GLY & 351 & H-acceptor & 3.17 \\
\hline & $\mathrm{N}$ & GLU & 206 & ionic & 3.13 \\
\hline & 6-ring & HIS & 203 & pi-H & 3.92 \\
\hline \multirow[t]{2}{*}{8} & $\mathrm{~N}$ & GLU & 206 & ionic & 3.65 \\
\hline & $\mathrm{N}$ & GLU & 206 & ionic & 3.86 \\
\hline 9 & $\mathrm{O}$ & HIS & 203 & H-acceptor & 3.61 \\
\hline
\end{tabular}




\begin{tabular}{|c|c|c|c|c|c|}
\hline \multirow[t]{2}{*}{ Conformer } & \multirow{2}{*}{$\begin{array}{l}\text { Ligand } \\
\mathrm{O}\end{array}$} & \multicolumn{2}{|c|}{ Residues in TMPRSS2 } & \multirow{2}{*}{$\frac{\text { Interaction }}{\mathrm{H} \text {-acceptor }}$} & \multirow{2}{*}{$\begin{array}{c}\text { Distance } \\
3.27\end{array}$} \\
\hline & & HIS & 203 & & \\
\hline & $\mathrm{N}$ & GLU & 206 & ionic & 3.6 \\
\hline & $\mathrm{N}$ & GLU & 206 & ionic & 3.7 \\
\hline & $\mathrm{N}$ & GLU & 206 & ionic & 3.69 \\
\hline & $\mathrm{N}$ & $\overline{G L U}$ & 206 & ionic & 3.55 \\
\hline \multirow[t]{6}{*}{10} & $\mathrm{O}$ & HIS & 203 & H-acceptor & 3.39 \\
\hline & $\mathrm{N}$ & GLU & 206 & ionic & 3.77 \\
\hline & $\mathrm{N}$ & GLU & 206 & ionic & 3.91 \\
\hline & $\mathrm{N}$ & GLU & 206 & ionic & 3.91 \\
\hline & $\mathrm{N}$ & GLU & 206 & ionic & 3.15 \\
\hline & $\mathrm{N}$ & GLU & 206 & ionic & 3.64 \\
\hline \multirow[t]{4}{*}{11} & $\mathrm{~N}$ & GLU & 206 & ionic & 3.86 \\
\hline & $\mathrm{N}$ & GLU & 206 & ionic & 3.49 \\
\hline & $\mathrm{N}$ & GLU & 206 & ionic & 2.93 \\
\hline & $\mathrm{N}$ & GLU & 206 & ionic & 4 \\
\hline \multirow[t]{4}{*}{12} & $\mathrm{~N}$ & GLU & 206 & H-donor & 2.94 \\
\hline & $\mathrm{N}$ & GLU & 206 & H-donor & 3.3 \\
\hline & $\mathrm{N}$ & GLU & 206 & ionic & 2.94 \\
\hline & $\mathrm{N}$ & GLU & 206 & ionic & 3.3 \\
\hline \multirow[t]{4}{*}{13} & $\mathrm{~N}$ & GLU & 206 & H-donor & 2.98 \\
\hline & $\mathrm{N}$ & GLU & 206 & ionic & 2.98 \\
\hline & $\mathrm{N}$ & GLU & 206 & ionic & 3.89 \\
\hline & $\mathrm{N}$ & GLU & 206 & ionic & 3.67 \\
\hline \multirow[t]{2}{*}{14} & $\mathrm{~N}$ & GLU & 206 & ionic & 3.75 \\
\hline & $\mathrm{N}$ & GLU & 206 & ionic & 3.45 \\
\hline \multirow[t]{5}{*}{15} & $\mathrm{~N}$ & GLU & 206 & H-donor & 3.55 \\
\hline & $\mathrm{O}$ & HIS & 203 & H-acceptor & 2.96 \\
\hline & $\mathrm{N}$ & GLU & 206 & ionic & 3.55 \\
\hline & $\mathrm{N}$ & GLU & 206 & ionic & 2.87 \\
\hline & 6-ring & ASN & 249 & pi-H & 4.09 \\
\hline \multirow[t]{5}{*}{16} & $\mathrm{~N}$ & GLU & 206 & H-donor & 3.24 \\
\hline & $\mathrm{N}$ & GLU & 206 & H-donor & 2.95 \\
\hline & $\mathrm{N}$ & GLU & 206 & ionic & 3.24 \\
\hline & $\mathrm{N}$ & GLU & 206 & ionic & 3.51 \\
\hline & $\mathrm{N}$ & GLU & 206 & ionic & 2.95 \\
\hline \multirow[t]{3}{*}{17} & $\mathrm{~N}$ & GLU & 206 & ionic & 3.68 \\
\hline & $\mathrm{N}$ & GLU & 206 & ionic & 3.91 \\
\hline & $\mathrm{N}$ & GLU & 206 & ionic & 3.5 \\
\hline 18 & $\mathrm{~N}$ & GLU & 206 & H-donor & 3.23 \\
\hline & $\mathrm{N}$ & GLU & 206 & H-donor & 2.95 \\
\hline & $\mathrm{O}$ & HIS & 203 & H-acceptor & 3.16 \\
\hline & $\mathrm{O}$ & HIS & 203 & H-acceptor & 2.91 \\
\hline & $\mathrm{N}$ & GLU & 206 & ionic & 2.9 \\
\hline & $\mathrm{N}$ & GLU & 206 & ionic & 3.23 \\
\hline & $\mathrm{N}$ & GLU & 206 & ionic & 3.87 \\
\hline & $\mathrm{N}$ & GLU & 206 & ionic & 2.95 \\
\hline 19 & $\mathrm{~N}$ & SER & 379 & H-donor & 3.03 \\
\hline 20 & $\mathrm{~N}$ & GLU & 206 & H-donor & 2.95 \\
\hline & $\mathrm{O}$ & HIS & 203 & H-acceptor & 3.58 \\
\hline & $\mathrm{N}$ & GLU & 206 & ionic & 3.15 \\
\hline & $\mathrm{N}$ & GLU & 206 & ionic & 2.95 \\
\hline & $\mathrm{N}$ & GLU & 206 & ionic & 3.11 \\
\hline 21 & $\mathrm{~N}$ & SER & 348 & H-donor & 2.9 \\
\hline 22 & $\mathrm{~N}$ & GLU & 206 & H-donor & 3.23 \\
\hline & $\mathrm{N}$ & GLU & 206 & H-donor & 3.07 \\
\hline & $\mathrm{N}$ & GLU & 206 & ionic & 3.23 \\
\hline & $\mathrm{N}$ & GLU & 206 & ionic & 3.54 \\
\hline & $\mathrm{N}$ & $\overline{G L U}$ & 206 & ionic & 3.07 \\
\hline 23 & $\mathrm{~N}$ & GLU & 206 & H-donor & 2.83 \\
\hline & $\mathrm{N}$ & GLU & 206 & ionic & 2.83 \\
\hline & $\mathrm{N}$ & GLU & 206 & ionic & 3.56 \\
\hline 24 & $\mathrm{O}$ & GLN & 350 & H-acceptor & 3.23 \\
\hline & $\mathrm{O}$ & HIS & 203 & H-acceptor & 2.98 \\
\hline & $\mathrm{N}$ & GLU & 206 & ionic & 2.87 \\
\hline & $\mathrm{N}$ & GLU & 206 & ionic & 4 \\
\hline & $\mathrm{N}$ & GLU & 206 & ionic & 3.53 \\
\hline
\end{tabular}




\begin{tabular}{l|l|c|c|c|c} 
Conformer & Ligand & \multicolumn{2}{|c}{ Residues in TMPRSS2 } & Interaction & Distance \\
\hline & N & GLU & 206 & ionic & 3.37 \\
\hline & N & GLU & 206 & ionic & 3.62 \\
\hline & N & GLU & 206 & ionic & 3.37
\end{tabular}

Table S15. Interaction report of each conformer of Edoxaban. Number of conformer, Atom of compound, Amino acid in TMPRSS2, Type of interaction and Distance in angstroms.

\begin{tabular}{|c|c|c|c|c|c|}
\hline \multirow{2}{*}{$\frac{\text { Conformer }}{1}$} & \multirow{2}{*}{$\begin{array}{l}\text { Ligand } \\
\mathrm{N}\end{array}$} & \multicolumn{2}{|c|}{ Residues in TMPRSS2 } & \multirow{2}{*}{$\frac{\text { Interaction }}{\mathrm{H} \text {-donor }}$} & \multirow{2}{*}{$\frac{\text { Distance }}{3.06}$} \\
\hline & & HIS & 186 & & \\
\hline & $\mathrm{O}$ & HIS & 203 & H-acceptor & 3.16 \\
\hline 2 & $\mathrm{O}$ & HIS & 203 & H-acceptor & 3.35 \\
\hline \multirow[t]{3}{*}{3} & $\mathrm{~N}$ & GLU & 206 & H-donor & 2.84 \\
\hline & $\mathrm{O}$ & HIS & 203 & H-acceptor & 3.08 \\
\hline & $\mathrm{N}$ & GLU & 206 & ionic & 2.84 \\
\hline \multirow[t]{4}{*}{4} & $\mathrm{~N}$ & GLU & 206 & H-donor & 2.99 \\
\hline & $\mathrm{O}$ & GLY & 378 & H-acceptor & 2.89 \\
\hline & $\mathrm{O}$ & GLY & 351 & H-acceptor & 3.23 \\
\hline & $\mathrm{N}$ & GLU & 206 & ionic & 2.99 \\
\hline \multirow[t]{4}{*}{5} & $\mathrm{~N}$ & GLU & 206 & H-donor & 2.91 \\
\hline & $\mathrm{O}$ & HIS & 203 & H-acceptor & 3.06 \\
\hline & $\mathrm{N}$ & GLU & 206 & ionic & 2.91 \\
\hline & 5-ring & HIS & 203 & pi-cation & 3.92 \\
\hline \multirow[t]{2}{*}{6} & $\mathrm{~N}$ & SER & 348 & H-donor & 3.24 \\
\hline & $\mathrm{O}$ & HIS & 203 & H-acceptor & 3.02 \\
\hline \multirow[t]{3}{*}{7} & $\mathrm{O}$ & CYS & 381 & H-donor & 3.44 \\
\hline & $\mathrm{O}$ & HIS & 203 & H-acceptor & 3.16 \\
\hline & 6-ring & HIS & 203 & pi-cation & 4.48 \\
\hline \multirow[t]{4}{*}{8} & $\mathrm{~N}$ & GLU & 206 & H-donor & 2.84 \\
\hline & $\mathrm{O}$ & GLY & 351 & H-acceptor & 3.07 \\
\hline & $\mathrm{N}$ & GLU & 206 & ionic & 2.84 \\
\hline & 6-ring & HIS & 203 & pi-cation & 4.32 \\
\hline 9 & $\mathrm{O}$ & GLY & 378 & H-acceptor & 2.98 \\
\hline \multirow[t]{2}{*}{10} & $\mathrm{~S}$ & VAL & 187 & H-donor & 3.74 \\
\hline & $\mathrm{N}$ & SER & 348 & H-donor & 3.16 \\
\hline 11 & $\mathrm{O}$ & GLY & 351 & H-acceptor & 3.08 \\
\hline \multirow[t]{3}{*}{12} & $\mathrm{O}$ & GLY & 351 & H-acceptor & 2.86 \\
\hline & $\mathrm{O}$ & HIS & 203 & H-acceptor & 2.98 \\
\hline & $\mathrm{N}$ & GLU & 206 & ionic & 3.81 \\
\hline \multirow[t]{3}{*}{13} & $\mathrm{O}$ & GLY & 351 & H-acceptor & 3.07 \\
\hline & $\mathrm{O}$ & HIS & 203 & H-acceptor & 3.1 \\
\hline & $\mathrm{N}$ & GLU & 206 & ionic & 3.98 \\
\hline \multirow[t]{2}{*}{14} & $\mathrm{~N}$ & TRP & 377 & cation-pi & 4.23 \\
\hline & $\mathrm{N}$ & TRP & 377 & cation-pi & 4.48 \\
\hline \multirow[t]{5}{*}{15} & $\mathrm{~N}$ & GLU & 206 & H-donor & 3.22 \\
\hline & $\mathrm{O}$ & HIS & 203 & H-acceptor & 3.3 \\
\hline & $\mathrm{O}$ & HIS & 203 & H-acceptor & 2.89 \\
\hline & $\mathrm{N}$ & GLU & 206 & ionic & 3.22 \\
\hline & $\mathrm{N}$ & GLU & 206 & ionic & 3.35 \\
\hline 16 & $\mathrm{~N}$ & GLU & 206 & H-donor & 2.75 \\
\hline & $\mathrm{O}$ & HIS & 203 & H-acceptor & 3.47 \\
\hline & $\mathrm{N}$ & GLU & 206 & ionic & 2.75 \\
\hline 17 & $\mathrm{O}$ & HIS & 203 & H-acceptor & 2.92 \\
\hline & 6-ring & GLY & 380 & pi-H & 4.24 \\
\hline 18 & $\mathrm{~N}$ & GLN & 350 & H-donor & 2.96 \\
\hline 19 & $\mathrm{~S}$ & SER & 348 & H-donor & 4.08 \\
\hline & 6-ring & CYS & 381 & pi-H & 4.61 \\
\hline 20 & $\mathrm{O}$ & GLY & 351 & H-acceptor & 3.15 \\
\hline 21 & $\mathrm{CL}$ & SER & 348 & H-donor & 3.43 \\
\hline & $\mathrm{C}$ & TRP & 215 & H-pi & 4.94 \\
\hline 22 & $\mathrm{O}$ & HIS & 203 & H-acceptor & 2.99 \\
\hline 23 & $\mathrm{~N}$ & CYS & 349 & H-donor & 3.26 \\
\hline & $\mathrm{N}$ & ASN & 249 & H-donor & 3 \\
\hline & $\mathrm{O}$ & HIS & 203 & H-acceptor & 3.06 \\
\hline 24 & $\mathrm{~N}$ & GLU & 206 & H-donor & 3.45 \\
\hline & $\mathrm{O}$ & HIS & 203 & H-acceptor & 3.32 \\
\hline & $\mathrm{N}$ & GLU & 206 & ionic & 3.45 \\
\hline & $\mathrm{N}$ & GLU & 206 & ionic & 3.8 \\
\hline
\end{tabular}


Table S16. Interaction report of each conformer of NCGC00386477. Number of conformer, Atom of compound, Amino acid in TMPRSS2, Type of interaction and Distance in angstroms.

\begin{tabular}{|c|c|c|c|c|c|}
\hline \multirow{2}{*}{$\begin{array}{c}\text { Conformer } \\
1 \\
\end{array}$} & \multirow{2}{*}{$\begin{array}{l}\text { Ligand } \\
\mathrm{N}\end{array}$} & \multicolumn{2}{|c|}{ Residues in TMPRSS2 } & \multirow{2}{*}{$\begin{array}{r}\text { Interaction } \\
\text { H-donor }\end{array}$} & \multirow{2}{*}{$\begin{array}{c}\text { Distance } \\
2.86\end{array}$} \\
\hline & & GLU & 206 & & \\
\hline & $\mathrm{N}$ & LYS & 383 & H-acceptor & 3.01 \\
\hline & $\mathrm{N}$ & GLU & 206 & ionic & 2.86 \\
\hline & $\mathrm{N}$ & GLU & 206 & ionic & 3.82 \\
\hline \multirow[t]{2}{*}{2} & $\mathrm{~N}$ & GLU & 206 & H-donor & 2.96 \\
\hline & $\mathrm{N}$ & GLU & 206 & ionic & 2.96 \\
\hline \multirow[t]{2}{*}{3} & $\mathrm{~N}$ & GLU & 206 & H-donor & 2.95 \\
\hline & $\mathrm{N}$ & GLU & 206 & ionic & 2.95 \\
\hline \multirow[t]{3}{*}{4} & $\mathrm{~N}$ & SER & 348 & H-donor & 2.9 \\
\hline & $\mathrm{N}$ & GLY & 378 & H-donor & 3.2 \\
\hline & 6-ring & SER & 379 & pi-H & 4.69 \\
\hline \multirow[t]{3}{*}{5} & $\mathrm{O}$ & HIS & 203 & H-acceptor & 2.98 \\
\hline & $\mathrm{N}$ & LYS & 383 & H-acceptor & 2.99 \\
\hline & 5-ring & CYS & 381 & pi-H & 4.28 \\
\hline \multirow[t]{4}{*}{6} & $\mathrm{~N}$ & GLU & 206 & H-donor & 2.89 \\
\hline & $\mathrm{N}$ & LYS & 383 & H-acceptor & 3.03 \\
\hline & $\mathrm{N}$ & GLU & 206 & ionic & 2.89 \\
\hline & 5-ring & CYS & 381 & pi-H & 4.36 \\
\hline 7 & 6-ring & LEU & 209 & pi-H & 3.9 \\
\hline \multirow[t]{3}{*}{8} & $\mathrm{~N}$ & GLU & 206 & H-donor & 2.92 \\
\hline & $\mathrm{N}$ & GLU & 206 & ionic & 2.92 \\
\hline & $\mathrm{N}$ & GLU & 206 & ionic & 3.54 \\
\hline \multirow[t]{2}{*}{9} & $\mathrm{~N}$ & THR & 254 & H-donor & 3.03 \\
\hline & $\mathrm{N}$ & LYS & 302 & H-acceptor & 3.48 \\
\hline \multirow[t]{3}{*}{10} & $\mathrm{~N}$ & GLU & 206 & H-donor & 2.96 \\
\hline & $\mathrm{N}$ & LYS & 383 & H-acceptor & 3.15 \\
\hline & $\mathrm{N}$ & GLU & 206 & ionic & 2.96 \\
\hline \multirow[t]{3}{*}{11} & $\mathrm{~N}$ & GLY & 378 & H-donor & 3.04 \\
\hline & $\mathrm{O}$ & HIS & 203 & H-acceptor & 3.41 \\
\hline & 6-ring & HIS & 203 & pi-cation & 3.82 \\
\hline 12 & $\mathrm{~N}$ & LYS & 383 & H-acceptor & 2.99 \\
\hline 13 & 5-ring & VAL & 187 & pi-H & 4.08 \\
\hline \multirow[t]{4}{*}{14} & $\mathrm{~N}$ & GLU & 206 & H-donor & 2.89 \\
\hline & $\mathrm{N}$ & GLU & 206 & ionic & 2.89 \\
\hline & $\mathrm{N}$ & GLU & 206 & ionic & 3.79 \\
\hline & 6-ring & VAL & 187 & pi-H & 4.49 \\
\hline \multirow[t]{2}{*}{15} & $\mathrm{~N}$ & SER & 379 & H-donor & 3.24 \\
\hline & $\mathrm{O}$ & HIS & 203 & H-acceptor & 3.21 \\
\hline 16 & $\mathrm{O}$ & HIS & 203 & H-acceptor & 3.29 \\
\hline 17 & $\mathrm{~N}$ & GLU & 206 & ionic & 3.91 \\
\hline \multirow[t]{2}{*}{18} & $\mathrm{~N}$ & GLU & 206 & H-donor & 2.88 \\
\hline & $\mathrm{N}$ & GLU & 206 & ionic & 2.88 \\
\hline \multirow[t]{4}{*}{19} & $\mathrm{~N}$ & GLU & 206 & H-donor & 3.56 \\
\hline & $\mathrm{N}$ & LYS & 383 & H-acceptor & 2.99 \\
\hline & $\mathrm{N}$ & GLU & 206 & ionic & 3.56 \\
\hline & $\mathrm{N}$ & GLU & 206 & ionic & 3.48 \\
\hline \multirow[t]{4}{*}{20} & $\mathrm{~N}$ & GLU & 206 & H-donor & 2.9 \\
\hline & $\mathrm{N}$ & GLU & 206 & ionic & 2.9 \\
\hline & $\mathrm{N}$ & GLU & 206 & ionic & 4 \\
\hline & 6-ring & SER & 379 & pi-H & 4.62 \\
\hline
\end{tabular}

Table S17. Interaction report of each conformer of Nafamostat. Number of conformer, Atom of compound, Amino acid in TMPRSS2, Type of interaction and Distance in angstroms.

\begin{tabular}{c|l|c|c|c|c} 
Conformer & Ligand & \multicolumn{2}{c}{ Residues in TMPRSS2 } & Interaction & Distance \\
\hline $\mathbf{1}$ & N & GLU & 206 & H-donor & 2.91 \\
\hline & N & SER & 348 & H-donor & 3.01 \\
\hline & N & GLY & 351 & H-donor & 2.98 \\
\hline & N & SER & 348 & H-donor & 3.14 \\
\hline & N & GLU & 206 & ionic & 2.91 \\
\hline $\mathbf{2}$ & N & SER & 348 & H-donor & 2.72 \\
\hline & N & GLU & 206 & ionic & 3.73 \\
\hline $\mathbf{3}$ & N & GLU & 206 & H-donor & 2.94 \\
\hline & N & SER & 348 & H-donor & 2.98
\end{tabular}




\begin{tabular}{|c|c|c|c|c|c|}
\hline \multirow[t]{2}{*}{ Conformer } & \multirow{2}{*}{$\begin{array}{l}\text { Ligand } \\
\mathrm{N}\end{array}$} & \multicolumn{2}{|c|}{ Residues in TMPRSS2 } & \multirow{2}{*}{$\begin{array}{c}\text { Interaction } \\
\text { H-donor }\end{array}$} & \multirow{2}{*}{$\begin{array}{c}\text { Distance } \\
2.99\end{array}$} \\
\hline & & GLY & 351 & & \\
\hline & $\mathrm{N}$ & SER & 348 & H-donor & 3.04 \\
\hline & $\mathrm{N}$ & GLU & 206 & ionic & 2.94 \\
\hline \multirow[t]{3}{*}{4} & $\mathrm{~N}$ & SER & 348 & H-donor & 2.86 \\
\hline & $\mathrm{N}$ & GLU & 206 & ionic & 3.46 \\
\hline & $\mathrm{N}$ & GLU & 206 & ionic & 3.23 \\
\hline \multirow{2}{*}{5} & $\mathrm{~N}$ & GLU & 206 & H-donor & 2.88 \\
\hline & $\mathrm{N}$ & GLU & 206 & ionic & 2.88 \\
\hline \multirow[t]{3}{*}{6} & $\mathrm{~N}$ & SER & 348 & H-donor & 2.76 \\
\hline & $\mathrm{N}$ & GLU & 206 & H-donor & 2.87 \\
\hline & $\mathrm{N}$ & GLU & 206 & ionic & 2.87 \\
\hline \multirow[t]{4}{*}{7} & $\mathrm{~N}$ & GLU & 206 & H-donor & 2.93 \\
\hline & $\mathrm{N}$ & SER & 348 & H-donor & 3.08 \\
\hline & $\mathrm{N}$ & SER & 348 & H-donor & 2.91 \\
\hline & $\mathrm{N}$ & GLU & 206 & ionic & 2.93 \\
\hline \multirow[t]{5}{*}{8} & $\mathrm{~N}$ & GLY & 378 & H-donor & 3.09 \\
\hline & $\mathrm{N}$ & SER & 348 & H-donor & 2.78 \\
\hline & $\mathrm{N}$ & GLU & 206 & ionic & 3.63 \\
\hline & $\mathrm{N}$ & GLU & 206 & ionic & 3.41 \\
\hline & 6-ring & HIS & 203 & pi-cation & 4.35 \\
\hline \multirow[t]{4}{*}{9} & $\mathrm{~N}$ & GLU & 206 & H-donor & 2.99 \\
\hline & $\mathrm{N}$ & CYS & 349 & H-donor & 3.17 \\
\hline & $\mathrm{N}$ & SER & 348 & H-donor & 2.93 \\
\hline & $\mathrm{N}$ & GLU & 206 & ionic & 2.99 \\
\hline \multirow[t]{3}{*}{10} & $\mathrm{~N}$ & SER & 348 & H-donor & 2.94 \\
\hline & $\mathrm{N}$ & GLY & 351 & H-donor & 3.05 \\
\hline & $\mathrm{N}$ & SER & 348 & H-donor & 3.08 \\
\hline \multirow[t]{3}{*}{11} & $\mathrm{~N}$ & GLU & 206 & H-donor & 2.92 \\
\hline & $\mathrm{N}$ & CYS & 349 & H-donor & 3.15 \\
\hline & $\mathrm{N}$ & GLU & 206 & ionic & 2.92 \\
\hline 12 & $\mathrm{~N}$ & GLU & 206 & H-donor & 3.48 \\
\hline & $\mathrm{N}$ & SER & 348 & H-donor & 3.49 \\
\hline & $\mathrm{N}$ & GLU & 206 & ionic & 3.48 \\
\hline 13 & $\mathrm{~N}$ & GLU & 206 & H-donor & 2.94 \\
\hline & $\mathrm{N}$ & GLY & 351 & H-donor & 3.17 \\
\hline & $\mathrm{N}$ & GLU & 206 & ionic & 2.94 \\
\hline & $\mathrm{N}$ & ASP & 352 & ionic & 3.91 \\
\hline 14 & $\mathrm{~N}$ & GLU & 206 & H-donor & 2.96 \\
\hline & $\mathrm{N}$ & CYS & 349 & H-donor & 3.23 \\
\hline & $\mathrm{N}$ & SER & 348 & H-donor & 2.81 \\
\hline & $\mathrm{N}$ & GLU & 206 & ionic & 2.96 \\
\hline 15 & $\mathrm{~N}$ & SER & 348 & H-donor & 2.81 \\
\hline & $\mathrm{N}$ & GLU & 206 & ionic & 3.48 \\
\hline & $\mathrm{N}$ & GLU & 206 & ionic & 3.24 \\
\hline 16 & $\mathrm{~N}$ & SER & 348 & H-donor & 2.72 \\
\hline & $\mathrm{N}$ & CYS & 349 & H-donor & 3.07 \\
\hline & $\mathrm{N}$ & GLU & 206 & ionic & 3.38 \\
\hline & $\mathrm{N}$ & GLU & 206 & ionic & 3.91 \\
\hline 17 & $\mathrm{~N}$ & SER & 348 & H-donor & 3.21 \\
\hline & $\mathrm{N}$ & SER & 348 & H-donor & 2.94 \\
\hline & $\mathrm{N}$ & GLU & 206 & ionic & 3.37 \\
\hline & $\mathrm{N}$ & GLU & 206 & ionic & 3.26 \\
\hline & 6-ring & VAL & 187 & pi-H & 3.88 \\
\hline 18 & $\mathrm{~N}$ & CYS & 349 & H-donor & 3.02 \\
\hline & $\mathrm{N}$ & GLU & 206 & H-donor & 3.05 \\
\hline & $\mathrm{N}$ & GLU & 206 & H-donor & 3.22 \\
\hline & $\mathrm{N}$ & GLU & 206 & ionic & 3.05 \\
\hline & $\mathrm{N}$ & GLU & 206 & ionic & 3.95 \\
\hline & $\mathrm{N}$ & GLU & 206 & ionic & 3.79 \\
\hline & $\mathrm{N}$ & GLU & 206 & ionic & 3.22 \\
\hline 19 & $\mathrm{~N}$ & SER & 348 & H-donor & 2.72 \\
\hline & $\mathrm{N}$ & CYS & 349 & H-donor & 3.07 \\
\hline & $\mathrm{N}$ & GLU & 206 & ionic & 3.67 \\
\hline & $\mathrm{N}$ & GLU & 206 & ionic & 3.94 \\
\hline & $\mathrm{N}$ & GLU & 206 & ionic & 3.68 \\
\hline 20 & $\mathrm{~N}$ & GLU & 206 & H-donor & 2.85 \\
\hline
\end{tabular}




\begin{tabular}{|c|c|c|c|c|c|}
\hline \multirow{2}{*}{ Conformer } & \multirow{2}{*}{$\begin{array}{l}\text { Ligand } \\
\mathrm{N}\end{array}$} & \multicolumn{2}{|c|}{ Residues in TMPRSS2 } & \multirow{2}{*}{$\begin{array}{c}\text { Interaction } \\
\text { H-donor }\end{array}$} & \multirow{2}{*}{$\begin{array}{c}\text { Distance } \\
2.76\end{array}$} \\
\hline & & GLU & 206 & & \\
\hline & $\mathrm{N}$ & CYS & 349 & H-donor & 2.96 \\
\hline & $\mathrm{N}$ & CYS & 381 & H-donor & 4.06 \\
\hline & $\mathrm{N}$ & CYS & 381 & H-donor & 3.53 \\
\hline & $\mathrm{O}$ & HIS & 203 & H-acceptor & 3.18 \\
\hline & $\mathrm{N}$ & GLU & 206 & ionic & 2.85 \\
\hline & $\mathrm{N}$ & GLU & 206 & ionic & 2.76 \\
\hline \multirow{2}{*}{21} & $\mathrm{~N}$ & VAL & 187 & H-donor & 2.96 \\
\hline & $\mathrm{N}$ & GLY & 351 & H-donor & 2.78 \\
\hline \multirow[t]{6}{*}{22} & $\mathrm{~N}$ & HIS & 186 & H-donor & 3.01 \\
\hline & $\mathrm{N}$ & GLU & 206 & ionic & 2.83 \\
\hline & $\mathrm{N}$ & GLU & 206 & ionic & 3.52 \\
\hline & $\mathrm{N}$ & GLU & 206 & ionic & 3.61 \\
\hline & $\mathrm{N}$ & GLU & 206 & ionic & 3.69 \\
\hline & $\mathrm{N}$ & GLU & 206 & ionic & 3.64 \\
\hline \multirow[t]{10}{*}{23} & $\mathrm{~N}$ & GLN & 350 & H-donor & 2.82 \\
\hline & $\mathrm{N}$ & GLU & 206 & ionic & 3.03 \\
\hline & $\mathrm{N}$ & GLU & 206 & ionic & 3.46 \\
\hline & $\mathrm{N}$ & GLU & 206 & ionic & 3.05 \\
\hline & $\mathrm{N}$ & GLU & 206 & ionic & 3.73 \\
\hline & 6-ring & HIS & 203 & pi-cation & 4.49 \\
\hline & $\mathrm{N}$ & CYS & 381 & H-donor & 3.53 \\
\hline & $\mathrm{O}$ & HIS & 203 & H-acceptor & 3.18 \\
\hline & $\mathrm{N}$ & GLU & 206 & ionic & 2.85 \\
\hline & $\mathrm{N}$ & GLU & 206 & ionic & 2.76 \\
\hline \multirow[t]{2}{*}{21} & $\mathrm{~N}$ & VAL & 187 & H-donor & 2.96 \\
\hline & $\mathrm{N}$ & GLY & 351 & H-donor & 2.78 \\
\hline \multirow[t]{6}{*}{22} & $\mathrm{~N}$ & HIS & 186 & H-donor & 3.01 \\
\hline & $\mathrm{N}$ & GLU & 206 & ionic & 2.83 \\
\hline & $\mathrm{N}$ & GLU & 206 & ionic & 3.52 \\
\hline & $\mathrm{N}$ & GLU & 206 & ionic & 3.61 \\
\hline & $\mathrm{N}$ & GLU & 206 & ionic & 3.69 \\
\hline & $\mathrm{N}$ & GLU & 206 & ionic & 3.64 \\
\hline \multirow[t]{9}{*}{23} & $\mathrm{~N}$ & GLN & 350 & H-donor & 2.82 \\
\hline & $\mathrm{N}$ & GLU & 206 & ionic & 3.03 \\
\hline & $\mathrm{N}$ & GLU & 206 & ionic & 3.46 \\
\hline & $\mathrm{N}$ & GLU & 206 & ionic & 3.05 \\
\hline & $\mathrm{N}$ & GLU & 206 & ionic & 3.73 \\
\hline & 6-ring & HIS & 203 & pi-cation & 4.49 \\
\hline & $\mathrm{N}$ & GLU & 206 & ionic & 3.61 \\
\hline & $\mathrm{N}$ & GLU & 206 & ionic & 3.69 \\
\hline & $\mathrm{N}$ & GLU & 206 & ionic & 3.64 \\
\hline \multirow[t]{6}{*}{23} & $\mathrm{~N}$ & GLN & 350 & H-donor & 2.82 \\
\hline & $\mathrm{N}$ & GLU & 206 & ionic & 3.03 \\
\hline & $\mathrm{N}$ & GLU & 206 & ionic & 3.46 \\
\hline & $\mathrm{N}$ & GLU & 206 & ionic & 3.05 \\
\hline & $\mathrm{N}$ & GLU & 206 & ionic & 3.73 \\
\hline & 6-ring & HIS & 203 & pi-cation & 4.49 \\
\hline
\end{tabular}

Table S18. Interaction report of each conformer of NCGC00386945. Number of conformer, Atom of compound, Amino acid in TMPRSS2, Type of interaction and Distance in angstroms.

\begin{tabular}{c|l|c|c|c|c} 
Conformer & Ligand & \multicolumn{2}{c}{ Residues in TMPRSS2 } & Interaction & Distance \\
\hline $\mathbf{1}$ & N & GLU & 206 & H-donor & 3.46 \\
\hline & N & GLU & 206 & ionic & 3.46 \\
\hline $\mathbf{2}$ & N & GLU & 206 & H-donor & 2.88 \\
\hline & N & GLU & 206 & ionic & 2.88 \\
\hline $\mathbf{3}$ & N & CYS & 349 & H-donor & 3.07 \\
\hline $\mathbf{4}$ & N & SER & 348 & H-donor & 2.69 \\
\hline & N & SER & 379 & H-donor & 3.23 \\
\hline $\mathbf{5}$ & N & GLU & 206 & H-donor & 2.93 \\
\hline & N & GLU & 206 & ionic & 2.93 \\
\hline $\mathbf{6}$ & N & GLU & 206 & ionic & 3.46 \\
\hline $\mathbf{7}$ & N & GLU & 206 & H-donor & 2.94 \\
\hline $\mathbf{8}$ & N & GLU & 206 & ionic & 2.94 \\
\hline & N & CYS & 349 & H-donor & 3.08 \\
\hline & NLU & 206 & H-donor & 2.98
\end{tabular}




\begin{tabular}{|c|c|c|c|c|c|}
\hline \multirow{2}{*}{ Conformer } & \multirow{2}{*}{$\begin{array}{l}\text { Ligand } \\
\mathrm{N}\end{array}$} & \multicolumn{2}{|c|}{ Residues in TMPRSS2 } & \multirow{2}{*}{$\begin{array}{c}\text { Interaction } \\
\text { ionic }\end{array}$} & \multirow{2}{*}{$\begin{array}{c}\text { Distance } \\
2.98\end{array}$} \\
\hline & & GLU & 206 & & \\
\hline 9 & $\mathrm{~N}$ & SER & 348 & H-donor & 3.4 \\
\hline \multirow[t]{4}{*}{10} & $\mathrm{~N}$ & SER & 348 & H-donor & 2.86 \\
\hline & $\mathrm{N}$ & GLY & 351 & H-donor & 3.19 \\
\hline & $\mathrm{C}$ & GLU & 206 & H-donor & 3.54 \\
\hline & $\mathrm{N}$ & GLU & 206 & ionic & 4 \\
\hline \multirow[t]{3}{*}{11} & $\mathrm{O}$ & HIS & 203 & H-acceptor & 3.33 \\
\hline & $\mathrm{N}$ & GLU & 206 & ionic & 3.24 \\
\hline & $\mathrm{N}$ & GLU & 206 & ionic & 3.43 \\
\hline 12 & $\mathrm{~N}$ & GLU & 206 & ionic & 3.41 \\
\hline \multirow[t]{2}{*}{13} & $\mathrm{~N}$ & GLU & 206 & H-donor & 2.98 \\
\hline & $\mathrm{N}$ & GLU & 206 & ionic & 2.98 \\
\hline \multirow[t]{3}{*}{14} & $\mathrm{~N}$ & GLU & 206 & H-donor & 2.86 \\
\hline & $\mathrm{N}$ & CYS & 381 & H-donor & 4.47 \\
\hline & $\mathrm{N}$ & GLU & 206 & ionic & 2.86 \\
\hline \multirow[t]{4}{*}{15} & $\mathrm{~N}$ & GLU & 206 & H-donor & 2.94 \\
\hline & $\mathrm{N}$ & CYS & 381 & H-donor & 4.01 \\
\hline & $\mathrm{N}$ & GLU & 206 & ionic & 2.94 \\
\hline & $\mathrm{N}$ & GLU & 206 & ionic & 3.66 \\
\hline \multirow[t]{4}{*}{16} & $\mathrm{~N}$ & GLU & 206 & H-donor & 3.38 \\
\hline & $\mathrm{N}$ & GLY & 378 & H-donor & 2.97 \\
\hline & $\mathrm{N}$ & SER & 348 & H-donor & 2.76 \\
\hline & $\mathrm{N}$ & GLU & 206 & ionic & 3.38 \\
\hline \multirow[t]{2}{*}{17} & $\mathrm{~N}$ & TRP & 215 & cation-pi & 4.47 \\
\hline & 6-ring & HIS & 203 & pi-cation & 4.79 \\
\hline \multirow[t]{2}{*}{18} & $\mathrm{~N}$ & GLU & 206 & H-donor & 2.96 \\
\hline & $\mathrm{N}$ & GLU & 206 & ionic & 2.96 \\
\hline 19 & 6-ring & GLN & 350 & pi-H & 4.78 \\
\hline \multirow[t]{2}{*}{20} & $\mathrm{~N}$ & GLU & 206 & H-donor & 3.19 \\
\hline & $\mathrm{N}$ & GLU & 206 & ionic & 3.19 \\
\hline \multirow[t]{4}{*}{21} & $\mathrm{~N}$ & GLU & 206 & H-donor & 2.9 \\
\hline & $\mathrm{N}$ & SER & 379 & H-donor & 3.32 \\
\hline & $\mathrm{N}$ & GLU & 206 & ionic & 2.9 \\
\hline & $\mathrm{N}$ & GLU & 206 & ionic & 3.52 \\
\hline \multirow[t]{4}{*}{22} & $\mathrm{~N}$ & GLY & 378 & H-donor & 2.98 \\
\hline & $\mathrm{C}$ & GLU & 206 & H-donor & 3.5 \\
\hline & $\mathrm{N}$ & GLU & 206 & ionic & 3.71 \\
\hline & 6-ring & HIS & 203 & pi-cation & 3.84 \\
\hline \multirow[t]{2}{*}{23} & $\mathrm{~N}$ & GLU & 206 & ionic & 3.87 \\
\hline & $\mathrm{N}$ & GLU & 206 & ionic & 3.41 \\
\hline
\end{tabular}

Table S19. Interaction report of each conformer of Otamixaban. Number of conformer, Atom of compound, Amino acid in TMPRSS2, Type of interaction and Distance in angstroms.

\begin{tabular}{c|l|c|c|c|c} 
Conformer & Ligand & \multicolumn{2}{c}{ Residues in TMPRSS2 } & Interaction & Distance \\
\hline $\mathbf{1}$ & N & SER & 348 & H-donor & 3.09 \\
\hline & N & GLY & 351 & H-donor & 3 \\
\hline & N & SER & 348 & H-donor & 3.17 \\
\hline $\mathbf{2}$ & N & VAL & 205 & H-donor & 2.87 \\
\hline & N & GLU & 206 & ionic & 2.99 \\
\hline & N & GLU & 206 & ionic & 2.84 \\
\hline & 6-ring & HIS & 203 & pi-cation & 3.81 \\
\hline $\mathbf{3}$ & N & VAL & 205 & H-donor & 3.45 \\
\hline & N & VAL & 205 & H-donor & 3.32 \\
\hline & O & HIS & 203 & H-acceptor & 2.98 \\
\hline & O & LYS & 383 & H-acceptor & 3.02 \\
\hline & N & GLU & 206 & ionic & 3.05 \\
\hline & N & GLU & 206 & H-donor & 3.04 \\
\hline & N & GLU & 206 & ionic & 3.04 \\
\hline & N & GLU & 206 & ionic & 3.63 \\
\hline & 6-ring & ASN & 249 & pi-H & 4.74 \\
\hline & 6-ring & GLN & 350 & pi-H & 4.65 \\
\hline & N & GLU & 206 & H-donor & 3.03 \\
\hline & N & GLU & 206 & H-donor & 2.93 \\
\hline & O & HIS & 203 & H-acceptor & 2.89 \\
\hline & N & GLU & 206 & ionic & 3.03 \\
\hline & N & GLU & 206 & ionic & 2.93
\end{tabular}




\begin{tabular}{|c|c|c|c|c|c|}
\hline \multirow[t]{2}{*}{ Conformer } & \multirow{2}{*}{$\begin{array}{l}\text { Ligand } \\
\mathrm{N}\end{array}$} & \multicolumn{2}{|c|}{ Residues in TMPRSS2 } & \multirow{2}{*}{$\begin{array}{c}\text { Interaction } \\
\text { ionic }\end{array}$} & \multirow{2}{*}{$\begin{array}{c}\text { Distance } \\
3.87\end{array}$} \\
\hline & & GLU & 206 & & \\
\hline \multirow[t]{4}{*}{6} & $\mathrm{~N}$ & CYS & 349 & H-donor & 2.88 \\
\hline & $\mathrm{N}$ & CYS & 381 & H-donor & 3.52 \\
\hline & $\mathrm{O}$ & HIS & 203 & H-acceptor & 2.88 \\
\hline & 6-ring & VAL & 187 & pi-H & 4.1 \\
\hline \multirow[t]{2}{*}{7} & $\mathrm{~N}$ & GLU & 206 & H-donor & 2.83 \\
\hline & $\mathrm{N}$ & GLU & 206 & ionic & 2.83 \\
\hline \multirow[t]{2}{*}{8} & $\mathrm{~N}$ & GLN & 350 & H-donor & 2.91 \\
\hline & $\mathrm{O}$ & HIS & 203 & H-acceptor & 2.88 \\
\hline 9 & $\mathrm{~N}$ & GLY & 378 & H-donor & 2.77 \\
\hline \multirow[t]{2}{*}{$\mathbf{0}$} & $\mathrm{N}$ & VAL & 187 & H-donor & 3.09 \\
\hline & $\mathrm{N}$ & GLY & 351 & H-donor & 2.88 \\
\hline \multirow[t]{4}{*}{10} & $\mathrm{~N}$ & GLU & 206 & H-donor & 2.88 \\
\hline & $\mathrm{N}$ & GLU & 206 & H-donor & 2.99 \\
\hline & $\mathrm{N}$ & GLU & 206 & ionic & 2.88 \\
\hline & $\mathrm{N}$ & GLU & 206 & ionic & 2.99 \\
\hline \multirow[t]{3}{*}{11} & $\mathrm{~N}$ & SER & 348 & H-donor & 3.2 \\
\hline & $\mathrm{N}$ & SER & 348 & H-donor & 3.1 \\
\hline & $\mathrm{C}$ & CYS & 381 & H-donor & 4.36 \\
\hline \multirow[t]{3}{*}{12} & $\mathrm{~N}$ & CYS & 349 & H-donor & 2.98 \\
\hline & $\mathrm{N}$ & CYS & 349 & H-donor & 3.04 \\
\hline & $\mathrm{O}$ & HIS & 203 & H-acceptor & 2.92 \\
\hline \multirow[t]{2}{*}{13} & $\mathrm{~N}$ & GLY & 351 & H-donor & 2.83 \\
\hline & $\mathrm{O}$ & HIS & 203 & H-acceptor & 3.13 \\
\hline 14 & $\mathrm{~N}$ & GLY & 378 & H-donor & 2.99 \\
\hline 15 & $\mathrm{~N}$ & GLU & 206 & H-donor & 2.78 \\
\hline & $\mathrm{N}$ & GLU & 206 & H-donor & 3.43 \\
\hline & $\mathrm{N}$ & GLU & 206 & H-donor & 3.09 \\
\hline & $\mathrm{O}$ & HIS & 203 & H-acceptor & 2.93 \\
\hline & $\mathrm{N}$ & GLU & 206 & ionic & 2.78 \\
\hline & $\mathrm{N}$ & GLU & 206 & ionic & 3.43 \\
\hline & $\mathrm{N}$ & GLU & 206 & ionic & 3.09 \\
\hline & 6-ring & VAL & 187 & pi-H & 4.51 \\
\hline 16 & $\mathrm{~N}$ & GLU & 206 & H-donor & 3.07 \\
\hline & $\mathrm{N}$ & GLU & 206 & H-donor & 2.93 \\
\hline & $\mathrm{O}$ & HIS & 203 & H-acceptor & 2.95 \\
\hline & $\mathrm{N}$ & GLU & 206 & ionic & 3.07 \\
\hline & $\mathrm{N}$ & GLU & 206 & ionic & 2.93 \\
\hline & $\mathrm{N}$ & GLU & 206 & ionic & 3.79 \\
\hline 17 & $\mathrm{~N}$ & GLU & 206 & H-donor & 3.11 \\
\hline & $\mathrm{O}$ & THR & 254 & H-acceptor & 3.28 \\
\hline & $\mathrm{N}$ & GLU & 206 & ionic & 3.11 \\
\hline & $\mathrm{C}$ & TRP & 377 & H-pi & 3.99 \\
\hline & $\mathrm{C}$ & TRP & 377 & H-pi & 3.94 \\
\hline 18 & $\mathrm{~N}$ & GLU & 206 & H-donor & 2.9 \\
\hline & $\mathrm{N}$ & GLU & 206 & H-donor & 2.85 \\
\hline & $\mathrm{N}$ & GLU & 206 & ionic & 2.9 \\
\hline & $\mathrm{N}$ & GLU & 206 & ionic & 2.85 \\
\hline & 6-ring & LEU & 209 & pi-H & 4.55 \\
\hline 19 & $\mathrm{~N}$ & GLU & 206 & H-donor & 2.77 \\
\hline & $\mathrm{N}$ & GLU & 206 & ionic & 2.77 \\
\hline & $\mathrm{N}$ & GLU & 206 & ionic & 3.63 \\
\hline & 6-ring & HIS & 203 & pi-cation & 3.62 \\
\hline 20 & $\mathrm{~N}$ & VAL & 205 & H-donor & 2.97 \\
\hline & $\mathrm{N}$ & GLU & 206 & H-donor & 2.82 \\
\hline & $\mathrm{N}$ & GLU & 206 & ionic & 3.22 \\
\hline & $\mathrm{N}$ & GLU & 206 & ionic & 2.82 \\
\hline & 6-ring & HIS & 203 & pi-cation & 3.84 \\
\hline 21 & 6-ring & HIS & 203 & pi-cation & 3.6 \\
\hline & 6-ring & CYS & 204 & pi-H & 4.47 \\
\hline 22 & $\mathrm{~N}$ & CYS & 349 & H-donor & 3.62 \\
\hline 23 & $\mathrm{~N}$ & GLU & 206 & H-donor & 3.36 \\
\hline & $\mathrm{N}$ & GLU & 206 & ionic & 3.36 \\
\hline & $\mathrm{N}$ & GLU & 206 & ionic & 2.81 \\
\hline 24 & $\mathrm{~N}$ & GLU & 206 & H-donor & 2.86 \\
\hline & $\mathrm{N}$ & GLU & 206 & H-donor & 3.44 \\
\hline
\end{tabular}




\begin{tabular}{l|l|c|c|c|c}
\multirow{2}{*}{ Conformer } & Ligand & \multicolumn{2}{|c}{ Residues in TMPRSS2 } & Interaction & Distance \\
\hline & O & HIS & 203 & H-acceptor & 2.9 \\
\hline & N & GLU & 206 & ionic & 2.86 \\
\hline & N & GLU & 206 & ionic & 3.32 \\
\hline & N & GLU & 206 & ionic & 3.44
\end{tabular}

Table S20. Interaction report of each conformer of Darexaban. Number of conformer, Atom of compound,

Amino acid in TMPRSS2, Type of interaction and Distance in angstroms.

\begin{tabular}{|c|c|c|c|c|c|}
\hline \multirow{2}{*}{$\begin{array}{c}\text { Conformer } \\
1\end{array}$} & \multirow{2}{*}{$\begin{array}{l}\text { Ligand } \\
\text { 6-ring }\end{array}$} & \multicolumn{2}{|c|}{ Residues in TMPRSS2 } & \multirow{2}{*}{$\frac{\text { Interaction }}{\text { pi-H }}$} & \multirow{2}{*}{$\begin{array}{c}\text { Distance } \\
4.05\end{array}$} \\
\hline & & VAL & 187 & & \\
\hline 2 & 6-ring & HIS & 203 & pi-cation & 4.07 \\
\hline 3 & 6-ring & GLY & 351 & pi-H & 4.59 \\
\hline 4 & $\mathrm{~N}$ & GLU & 206 & ionic & 3.61 \\
\hline \multirow[t]{4}{*}{5} & $\mathrm{O}$ & HIS & 203 & H-acceptor & 2.97 \\
\hline & $\mathrm{N}$ & GLU & 206 & ionic & 3.94 \\
\hline & $\mathrm{N}$ & GLU & 206 & ionic & 3.66 \\
\hline & 6-ring & TYR & 250 & pi-H & 3.93 \\
\hline 6 & $\mathrm{~N}$ & GLU & 206 & ionic & 3.98 \\
\hline 7 & $\mathrm{C}$ & CYS & 349 & H-donor & 3.46 \\
\hline \multirow[t]{3}{*}{8} & $\mathrm{O}$ & HIS & 203 & H-acceptor & 2.97 \\
\hline & $\mathrm{N}$ & GLU & 206 & ionic & 3.4 \\
\hline & 6-ring & VAL & 187 & pi-H & 4.52 \\
\hline 9 & 6-ring & GLY & 351 & pi-H & 3.62 \\
\hline \multirow[t]{2}{*}{10} & 6-ring & HIS & 203 & pi-H & 4.19 \\
\hline & 6-ring & HIS & 203 & pi-cation & 3.52 \\
\hline \multirow[t]{2}{*}{11} & $\mathrm{O}$ & SER & 379 & H-donor & 2.89 \\
\hline & $\mathrm{C}$ & TRP & 377 & H-pi & 4.54 \\
\hline \multirow[t]{3}{*}{12} & $\mathrm{~N}$ & GLU & 206 & ionic & 3.66 \\
\hline & 6-ring & GLN & 350 & pi-H & 4.38 \\
\hline & 6-ring & GLY & 351 & pi-H & 3.69 \\
\hline \multirow[t]{3}{*}{13} & $\mathrm{O}$ & HIS & 203 & H-acceptor & 3.05 \\
\hline & $\mathrm{N}$ & GLU & 206 & ionic & 3.67 \\
\hline & 6-ring & GLY & 351 & pi-H & 4.35 \\
\hline 14 & 6-ring & VAL & 187 & pi-H & 4.01 \\
\hline \multirow[t]{4}{*}{15} & $\mathrm{~N}$ & GLU & 206 & ionic & 3.74 \\
\hline & $\mathrm{N}$ & CYS & 349 & H-donor & 3.1 \\
\hline & $\mathrm{O}$ & CYS & 381 & H-acceptor & 3.26 \\
\hline & $\mathrm{O}$ & LYS & 383 & H-acceptor & 2.93 \\
\hline 16 & $\mathrm{~N}$ & GLU & 206 & H-donor & 3.29 \\
\hline 17 & 6-ring & HIS & 203 & pi-cation & 3.9 \\
\hline \multirow[t]{2}{*}{18} & $\mathrm{~N}$ & GLU & 206 & H-donor & 2.94 \\
\hline & $\mathrm{N}$ & GLU & 206 & ionic & 2.94 \\
\hline
\end{tabular}

Table S21. Interaction report of each conformer of Gabexate. Number of conformer, Atom of compound, Amino acid in TMPRSS2, Type of interaction and Distance in angstroms.

\begin{tabular}{c|l|c|c|c|c} 
Conformer & Ligand & \multicolumn{2}{c}{ Residues in TMPRSS2 } & Interaction & Distance \\
\hline $\mathbf{1}$ & N & SER & 348 & H-donor & 3.13 \\
\hline & N & SER & 348 & H-donor & 3.03 \\
\hline $\mathbf{2}$ & N & GLU & 206 & H-donor & 2.89 \\
\hline & N & GLU & 206 & ionic & 3.53 \\
\hline & N & GLU & 206 & ionic & 2.89 \\
\hline & 6-ring & HIS & 203 & pi-H & 3.87 \\
\hline $\mathbf{3}$ & N & GLU & 206 & H-donor & 2.87 \\
\hline & O & GLY & 351 & H-acceptor & 3.27 \\
\hline & N & GLU & 206 & ionic & 2.87 \\
\hline & N & GLU & 206 & ionic & 3.43 \\
\hline $\mathbf{4}$ & N & CYS & 349 & H-donor & 3.02 \\
\hline $\mathbf{5}$ & N & CYS & 349 & H-donor & 2.95 \\
\hline & 6-ring & VAL & 187 & pi-H & 3.99 \\
\hline $\mathbf{6}$ & N & GLY & 351 & H-donor & 3.12 \\
\hline $\mathbf{7}$ & N & GLU & 206 & ionic & 3.14 \\
\hline $\mathbf{8}$ & N & GLU & 206 & H-donor & 2.79 \\
\hline & O & HIS & 203 & H-acceptor & 3.37 \\
\hline & N & GLU & 206 & ionic & 2.79 \\
\hline $\mathbf{9}$ & N & GLU & 206 & ionic & 3.48 \\
\hline
\end{tabular}




\begin{tabular}{|c|c|c|c|c|c|}
\hline \multirow[t]{2}{*}{ Conformer } & \multirow{2}{*}{$\begin{array}{l}\text { Ligand } \\
\mathrm{N}\end{array}$} & \multicolumn{2}{|c|}{ Residues in TMPRSS2 } & \multirow{2}{*}{$\begin{array}{r}\text { Interaction } \\
\text { H-donor }\end{array}$} & \multirow{2}{*}{$\begin{array}{c}\text { Distance } \\
3.34\end{array}$} \\
\hline & & CYS & 349 & & \\
\hline & $\mathrm{N}$ & CYS & 381 & H-donor & 4.26 \\
\hline \multirow[t]{5}{*}{10} & $\mathrm{~N}$ & GLU & 206 & H-donor & 3.2 \\
\hline & $\mathrm{N}$ & GLU & 206 & H-donor & 2.94 \\
\hline & $\mathrm{O}$ & HIS & 203 & H-acceptor & 3.02 \\
\hline & $\mathrm{N}$ & GLU & 206 & ionic & 3.2 \\
\hline & $\mathrm{N}$ & GLU & 206 & ionic & 2.94 \\
\hline \multirow[t]{5}{*}{11} & $\mathrm{~N}$ & GLU & 206 & H-donor & 2.88 \\
\hline & $\mathrm{N}$ & GLU & 206 & H-donor & 2.78 \\
\hline & $\mathrm{N}$ & GLU & 206 & ionic & 2.88 \\
\hline & $\mathrm{N}$ & GLU & 206 & ionic & 3.89 \\
\hline & $\mathrm{N}$ & GLU & 206 & ionic & 2.78 \\
\hline \multirow[t]{3}{*}{12} & $\mathrm{~N}$ & SER & 348 & H-donor & 3.14 \\
\hline & $\mathrm{N}$ & SER & 348 & H-donor & 2.94 \\
\hline & 6-ring & VAL & 187 & pi-H & 4.22 \\
\hline \multirow[t]{2}{*}{13} & $\mathrm{~N}$ & SER & 379 & H-donor & 2.92 \\
\hline & 6-ring & VAL & 187 & pi-H & 4.33 \\
\hline \multirow[t]{3}{*}{14} & $\mathrm{~N}$ & GLY & 378 & H-donor & 2.84 \\
\hline & $\mathrm{O}$ & HIS & 203 & H-acceptor & 3.18 \\
\hline & 6-ring & HIS & 203 & pi-H & 3.78 \\
\hline \multirow[t]{2}{*}{15} & $\mathrm{~N}$ & CYS & 349 & H-donor & 3.13 \\
\hline & $\mathrm{N}$ & CYS & 349 & H-donor & 3.04 \\
\hline \multirow[t]{5}{*}{16} & $\mathrm{~N}$ & GLU & 206 & H-donor & 3.14 \\
\hline & $\mathrm{N}$ & GLU & 206 & H-donor & 3.04 \\
\hline & $\mathrm{N}$ & GLU & 206 & ionic & 3.98 \\
\hline & $\mathrm{N}$ & GLU & 206 & ionic & 3.14 \\
\hline & $\mathrm{N}$ & GLU & 206 & ionic & 3.04 \\
\hline \multirow[t]{2}{*}{17} & $\mathrm{O}$ & HIS & 203 & H-acceptor & 2.97 \\
\hline & $\mathrm{N}$ & GLU & 206 & ionic & 3.95 \\
\hline 18 & $\mathrm{~N}$ & GLU & 206 & H-donor & 2.75 \\
\hline & $\mathrm{N}$ & ASN & 249 & H-donor & 3.21 \\
\hline & $\mathrm{N}$ & GLU & 206 & ionic & 3.62 \\
\hline & $\mathrm{N}$ & GLU & 206 & ionic & 2.75 \\
\hline 19 & $\mathrm{~N}$ & GLU & 206 & H-donor & 2.86 \\
\hline & $\mathrm{N}$ & GLU & 206 & ionic & 2.86 \\
\hline & $\mathrm{N}$ & GLU & 206 & ionic & 3.38 \\
\hline 20 & $\mathrm{~N}$ & GLU & 206 & ionic & 3.19 \\
\hline 21 & $\mathrm{~N}$ & GLU & 206 & ionic & 3.84 \\
\hline & $\mathrm{N}$ & GLU & 206 & ionic & 3.21 \\
\hline & $\mathrm{N}$ & GLU & 206 & ionic & 2.94 \\
\hline 22 & $\mathrm{O}$ & GLY & 351 & H-acceptor & 3.27 \\
\hline & $\mathrm{N}$ & GLU & 206 & ionic & 3.3 \\
\hline & $\mathrm{N}$ & GLU & 206 & ionic & 3.77 \\
\hline & $\mathrm{N}$ & GLU & 206 & ionic & 2.99 \\
\hline 23 & $\mathrm{~N}$ & GLU & 206 & H-donor & 2.93 \\
\hline & $\mathrm{N}$ & GLU & 206 & H-donor & 3.16 \\
\hline & $\mathrm{N}$ & GLU & 206 & ionic & 2.93 \\
\hline & $\mathrm{N}$ & GLU & 206 & ionic & 3.16 \\
\hline & $\mathrm{N}$ & GLU & 206 & ionic & 3.5 \\
\hline 24 & $\mathrm{~N}$ & SER & 348 & H-donor & 3.1 \\
\hline & $\mathrm{N}$ & SER & 348 & H-donor & 2.88 \\
\hline 25 & $\mathrm{~N}$ & GLU & 206 & H-donor & 2.85 \\
\hline & $\mathrm{N}$ & GLU & 206 & ionic & 2.85 \\
\hline 26 & $\mathrm{~N}$ & SER & 348 & H-donor & 3.42 \\
\hline & $\mathrm{N}$ & SER & 348 & H-donor & 2.82 \\
\hline 27 & $\mathrm{~N}$ & ASN & 249 & H-donor & 3.27 \\
\hline & $\mathrm{N}$ & GLU & 206 & H-donor & 2.76 \\
\hline & $\mathrm{O}$ & GLY & 351 & H-acceptor & 3.01 \\
\hline & $\mathrm{N}$ & GLU & 206 & ionic & 2.76 \\
\hline 28 & $\mathrm{~N}$ & GLU & 206 & H-donor & 3.1 \\
\hline & $\mathrm{N}$ & GLU & 206 & H-donor & 3.25 \\
\hline & $\mathrm{N}$ & GLU & 206 & H-donor & 2.88 \\
\hline & $\mathrm{O}$ & HIS & 203 & H-acceptor & 3.15 \\
\hline & $\mathrm{O}$ & GLY & 351 & H-acceptor & 3.12 \\
\hline & $\mathrm{N}$ & GLU & 206 & ionic & 3.1 \\
\hline & $\mathrm{N}$ & GLU & 206 & ionic & 3.25 \\
\hline
\end{tabular}




\begin{tabular}{l|l|c|c|c|c} 
Conformer & Ligand & \multicolumn{2}{|c|}{ Residues in TMPRS2 } & Interaction & Distance \\
\hline & $\mathrm{N}$ & GLU & 206 & ionic & 4 \\
\hline & $\mathrm{N}$ & GLU & 206 & ionic & 2.88
\end{tabular}

Table S22. Interaction report of each conformer of Letaxaban. Number of conformer, Atom of compound, Amino acid in TMPRSS2, Type of interaction and Distance in angstroms.

\begin{tabular}{|c|c|c|c|c|c|}
\hline \multirow{2}{*}{$\begin{array}{c}\text { Conformer } \\
1\end{array}$} & \multirow{2}{*}{$\begin{array}{l}\text { Ligand } \\
\mathrm{O}\end{array}$} & \multicolumn{2}{|c|}{ Residues in TMPRSS2 } & \multirow{2}{*}{$\begin{array}{c}\text { Interaction } \\
\text { H-donor }\end{array}$} & \multirow{2}{*}{$\begin{array}{c}\text { Distance } \\
3.01\end{array}$} \\
\hline & & SER & 348 & & \\
\hline & $\mathrm{O}$ & HIS & 203 & H-acceptor & 3.17 \\
\hline \multirow[t]{3}{*}{2} & $\mathrm{O}$ & HIS & 203 & H-acceptor & 2.91 \\
\hline & 6-ring & VAL & 187 & pi-H & 3.89 \\
\hline & 6-ring & VAL & 187 & pi-H & 4.65 \\
\hline 3 & $\mathrm{~N}$ & CYS & 349 & H-donor & 3.13 \\
\hline \multirow[t]{2}{*}{4} & $\mathrm{O}$ & VAL & 187 & H-donor & 3.09 \\
\hline & 6-ring & GLY & 380 & pi-H & 4.56 \\
\hline 5 & 6-ring & HIS & 203 & pi-cation & 3.72 \\
\hline \multirow[t]{2}{*}{6} & $\mathrm{O}$ & GLY & 351 & H-acceptor & 2.98 \\
\hline & 6-ring & GLN & 350 & pi-H & 3.74 \\
\hline \multirow[t]{3}{*}{7} & $\mathrm{O}$ & GLY & 351 & H-acceptor & 3.25 \\
\hline & 6-ring & VAL & 187 & pi-H & 4.44 \\
\hline & 6-ring & VAL & 187 & pi-H & 4 \\
\hline 8 & $\mathrm{O}$ & GLY & 351 & H-acceptor & 3.05 \\
\hline \multirow[t]{3}{*}{9} & $\mathrm{O}$ & VAL & 187 & H-donor & 3.3 \\
\hline & $\mathrm{O}$ & HIS & 203 & H-acceptor & 3.33 \\
\hline & 6-ring & ASN & 249 & pi-H & 4.12 \\
\hline \multirow[t]{2}{*}{10} & $\mathrm{O}$ & HIS & 203 & H-acceptor & 3.02 \\
\hline & 6-ring & VAL & 187 & pi-H & 4.46 \\
\hline \multirow[t]{4}{*}{11} & $\mathrm{O}$ & VAL & 187 & H-donor & 2.97 \\
\hline & $\mathrm{O}$ & HIS & 203 & H-acceptor & 2.91 \\
\hline & 6-ring & ASN & 249 & pi-H & 3.82 \\
\hline & 6-ring & ASN & 249 & pi-H & 4.05 \\
\hline 13 & $\mathrm{O}$ & HIS & 203 & H-acceptor & 2.95 \\
\hline 14 & $\mathrm{~N}$ & SER & 348 & H-donor & 3.07 \\
\hline 15 & $\mathrm{O}$ & SER & 348 & H-donor & 3 \\
\hline 16 & 6-ring & HIS & 203 & pi-cation & 4.22 \\
\hline \multirow[t]{2}{*}{17} & $\mathrm{O}$ & GLN & 350 & H-acceptor & 3.34 \\
\hline & $\mathrm{O}$ & HIS & 203 & H-acceptor & 3.32 \\
\hline 18 & $\mathrm{O}$ & ASN & 249 & H-acceptor & 3.1 \\
\hline 19 & $\mathrm{O}$ & HIS & 203 & H-acceptor & 2.89 \\
\hline \multirow[t]{2}{*}{20} & $\mathrm{O}$ & VAL & 187 & H-donor & 3 \\
\hline & 6-ring & ASN & 249 & pi-H & 3.91 \\
\hline \multirow[t]{2}{*}{21} & $\mathrm{C}$ & GLU & 206 & H-donor & 3.46 \\
\hline & $\mathrm{O}$ & HIS & 203 & H-acceptor & 2.98 \\
\hline
\end{tabular}

Table S23. Interaction report of each conformer of Argatroban. Number of conformer, Atom of compound, Amino acid in TMPRSS2, Type of interaction and Distance in angstroms.

\begin{tabular}{c|l|c|c|c|c} 
Conformer & Ligand & \multicolumn{2}{c}{ Residues in TMPRSS2 } & Interaction & Distance \\
\hline $\mathbf{1}$ & N & GLN & 350 & H-donor & 3.09 \\
\hline & N & GLN & 350 & H-donor & 3.18 \\
\hline & O & HIS & 203 & H-acceptor & 2.87 \\
\hline & O & HIS & 203 & ionic & 2.87 \\
\hline $\mathbf{2}$ & N & GLU & 206 & H-donor & 2.84 \\
\hline & O & HIS & 203 & H-acceptor & 2.91 \\
\hline & N & GLU & 206 & ionic & 3.87 \\
\hline & N & GLU & 206 & ionic & 2.84 \\
\hline & 6-ring & GLY & 351 & pi-H & 4.25 \\
\hline & N & VAL & 187 & H-donor & 2.91 \\
\hline & N & HIS & 203 & H-donor & 3.52 \\
\hline & N & GLU & 206 & H-donor & 3.34 \\
\hline & N & GLU & 206 & H-donor & 2.89 \\
\hline & O & HIS & 203 & H-acceptor & 3.19 \\
\hline & O & GLY & 351 & H-acceptor & 3.33 \\
\hline & O & HIS & 203 & ionic & 3.19 \\
\hline & O & HIS & 203 & ionic & 3.02 \\
\hline & N & GLU & 206 & ionic & 3.34 \\
\hline & N & GLU & 206 & ionic & 2.89
\end{tabular}




\begin{tabular}{|c|c|c|c|c|c|}
\hline \multirow{2}{*}{$\begin{array}{c}\text { Conformer } \\
4\end{array}$} & \multirow{2}{*}{$\begin{array}{l}\text { Ligand } \\
\mathrm{N}\end{array}$} & \multicolumn{2}{|c|}{ Residues in TMPRSS2 } & \multirow{2}{*}{$\begin{array}{r}\text { Interaction } \\
\text { H-donor }\end{array}$} & \multirow{2}{*}{$\begin{array}{c}\text { Distance } \\
2.9\end{array}$} \\
\hline & & GLU & 206 & & \\
\hline & $\mathrm{N}$ & HIS & 203 & H-donor & 3.26 \\
\hline & $\mathrm{N}$ & GLU & 206 & H-donor & 2.83 \\
\hline & $\mathrm{O}$ & HIS & 203 & ionic & 2.9 \\
\hline & $\mathrm{N}$ & GLU & 206 & ionic & 2.9 \\
\hline & $\mathrm{N}$ & GLU & 206 & ionic & 2.83 \\
\hline \multirow[t]{7}{*}{5} & $\mathrm{~N}$ & GLU & 206 & H-donor & 2.87 \\
\hline & $\mathrm{N}$ & GLU & 206 & H-donor & 2.89 \\
\hline & $\mathrm{O}$ & HIS & 203 & H-acceptor & 2.88 \\
\hline & $\mathrm{O}$ & HIS & 203 & ionic & 2.88 \\
\hline & $\mathrm{O}$ & HIS & 203 & ionic & 3.44 \\
\hline & $\mathrm{N}$ & GLU & 206 & ionic & 2.87 \\
\hline & $\mathrm{N}$ & GLU & 206 & ionic & 2.89 \\
\hline \multirow[t]{4}{*}{6} & $\mathrm{O}$ & HIS & 203 & H-acceptor & 2.78 \\
\hline & $\mathrm{O}$ & HIS & 203 & ionic & 2.78 \\
\hline & $\mathrm{N}$ & GLU & 206 & ionic & 3.1 \\
\hline & $\mathrm{N}$ & GLU & 206 & ionic & 3.49 \\
\hline \multirow[t]{4}{*}{7} & $\mathrm{~N}$ & SER & 348 & H-donor & 2.83 \\
\hline & $\mathrm{N}$ & CYS & 349 & H-donor & 3.19 \\
\hline & $\mathrm{O}$ & GLY & 351 & H-acceptor & 3.29 \\
\hline & $\mathrm{O}$ & HIS & 203 & H-acceptor & 3.1 \\
\hline \multirow[t]{6}{*}{8} & $\mathrm{~N}$ & CYS & 349 & H-donor & 3.29 \\
\hline & $\mathrm{O}$ & HIS & 203 & H-acceptor & 3.04 \\
\hline & $\mathrm{O}$ & HIS & 203 & H-acceptor & 2.96 \\
\hline & $\mathrm{O}$ & GLN & 350 & H-acceptor & 3.09 \\
\hline & $\mathrm{O}$ & HIS & 203 & ionic & 3.04 \\
\hline & $\mathrm{O}$ & HIS & 203 & ionic & 2.96 \\
\hline \multirow[t]{9}{*}{9} & $\mathrm{~N}$ & GLU & 206 & H-donor & 3.13 \\
\hline & $\mathrm{N}$ & VAL & 205 & H-donor & 2.84 \\
\hline & $\mathrm{N}$ & GLU & 206 & H-donor & 2.86 \\
\hline & $\mathrm{O}$ & HIS & 203 & H-acceptor & 3.01 \\
\hline & $\mathrm{O}$ & HIS & 203 & H-acceptor & 2.84 \\
\hline & $\mathrm{O}$ & HIS & 203 & ionic & 3.01 \\
\hline & $\mathrm{O}$ & HIS & 203 & ionic & 2.84 \\
\hline & $\mathrm{N}$ & GLU & 206 & ionic & 3.13 \\
\hline & $\mathrm{N}$ & GLU & 206 & ionic & 2.86 \\
\hline \multirow[t]{4}{*}{10} & $\mathrm{O}$ & HIS & 203 & H-acceptor & 2.98 \\
\hline & $\mathrm{N}$ & GLU & 206 & ionic & 2.86 \\
\hline & $\mathrm{N}$ & GLU & 206 & ionic & 3.58 \\
\hline & $\mathrm{N}$ & GLU & 206 & ionic & 3.29 \\
\hline 11 & $\mathrm{~N}$ & HIS & 186 & H-donor & 2.91 \\
\hline \multirow[t]{3}{*}{12} & $\mathrm{~N}$ & GLN & 350 & H-donor & 3.06 \\
\hline & $\mathrm{O}$ & HIS & 203 & H-acceptor & 2.73 \\
\hline & $\mathrm{O}$ & HIS & 203 & ionic & 2.73 \\
\hline \multirow[t]{3}{*}{13} & $\mathrm{O}$ & HIS & 203 & H-acceptor & 2.82 \\
\hline & $\mathrm{O}$ & GLY & 351 & H-acceptor & 3.15 \\
\hline & $\mathrm{O}$ & HIS & 203 & ionic & 2.82 \\
\hline 14 & $\mathrm{~N}$ & GLN & 350 & H-donor & 3.18 \\
\hline & $\mathrm{O}$ & GLY & 351 & H-acceptor & 3.09 \\
\hline & $\mathrm{O}$ & HIS & 203 & ionic & 2.96 \\
\hline & $\mathrm{N}$ & HIS & 186 & cation-pi & 4.55 \\
\hline 15 & $\mathrm{~N}$ & GLN & 350 & H-donor & 2.92 \\
\hline & $\mathrm{O}$ & HIS & 203 & H-acceptor & 2.83 \\
\hline & $\mathrm{O}$ & HIS & 203 & ionic & 2.83 \\
\hline & $\mathrm{O}$ & HIS & 203 & ionic & 3.41 \\
\hline 16 & $\mathrm{~N}$ & GLU & 206 & H-donor & 2.82 \\
\hline & $\mathrm{N}$ & GLU & 206 & H-donor & 2.96 \\
\hline & $\mathrm{O}$ & HIS & 203 & H-acceptor & 2.85 \\
\hline & $\mathrm{O}$ & HIS & 203 & ionic & 2.85 \\
\hline & $\mathrm{N}$ & GLU & 206 & ionic & 2.82 \\
\hline & $\mathrm{N}$ & GLU & 206 & ionic & 2.96 \\
\hline 17 & $\mathrm{~N}$ & GLU & 206 & H-donor & 2.85 \\
\hline & $\mathrm{N}$ & GLU & 206 & H-donor & 3.08 \\
\hline & $\mathrm{O}$ & HIS & 203 & H-acceptor & 2.84 \\
\hline & $\mathrm{O}$ & HIS & 203 & H-acceptor & 3.29 \\
\hline & $\mathrm{O}$ & HIS & 203 & ionic & 2.84 \\
\hline
\end{tabular}




\begin{tabular}{|c|c|c|c|c|c|}
\hline \multirow[t]{2}{*}{ Conformer } & \multirow{2}{*}{$\begin{array}{l}\text { Ligand } \\
\mathrm{O}\end{array}$} & \multicolumn{2}{|c|}{ Residues in TMPRSS2 } & \multirow{2}{*}{$\frac{\text { Interaction }}{\text { ionic }}$} & \multirow{2}{*}{$\begin{array}{c}\text { Distance } \\
3.29\end{array}$} \\
\hline & & HIS & 203 & & \\
\hline & $\mathrm{N}$ & GLU & 206 & ionic & 2.85 \\
\hline & $\mathrm{N}$ & GLU & 206 & ionic & 3.08 \\
\hline & $\mathrm{N}$ & GLU & 206 & ionic & 3.6 \\
\hline \multirow[t]{6}{*}{18} & $\mathrm{~N}$ & GLU & 206 & H-donor & 2.84 \\
\hline & $\mathrm{O}$ & HIS & 203 & H-acceptor & 2.86 \\
\hline & $\mathrm{O}$ & HIS & 203 & ionic & 2.86 \\
\hline & $\mathrm{O}$ & HIS & 203 & ionic & 3.5 \\
\hline & $\mathrm{N}$ & GLU & 206 & ionic & 3.2 \\
\hline & $\mathrm{N}$ & GLU & 206 & ionic & 2.84 \\
\hline \multirow[t]{4}{*}{19} & $\mathrm{~N}$ & GLY & 351 & H-donor & 3.06 \\
\hline & $\mathrm{O}$ & HIS & 203 & H-acceptor & 3 \\
\hline & $\mathrm{O}$ & HIS & 203 & ionic & 3 \\
\hline & $\mathrm{N}$ & ASP & 352 & ionic & 3.74 \\
\hline \multirow[t]{5}{*}{20} & $\mathrm{~N}$ & SER & 348 & H-donor & 2.88 \\
\hline & $\mathrm{O}$ & HIS & 203 & H-acceptor & 2.88 \\
\hline & $\mathrm{O}$ & HIS & 203 & ionic & 2.88 \\
\hline & $\mathrm{O}$ & HIS & 203 & ionic & 3.17 \\
\hline & 6-ring & GLY & 351 & pi-H & 4.58 \\
\hline \multirow[t]{2}{*}{21} & $\mathrm{~N}$ & SER & 348 & H-donor & 3.12 \\
\hline & $\mathrm{O}$ & HIS & 203 & ionic & 3.84 \\
\hline \multirow[t]{7}{*}{22} & $\mathrm{~N}$ & CYS & 349 & H-donor & 2.92 \\
\hline & $\mathrm{N}$ & GLY & 351 & H-donor & 3.08 \\
\hline & $\mathrm{O}$ & HIS & 203 & H-acceptor & 2.84 \\
\hline & $\mathrm{O}$ & HIS & 203 & H-acceptor & 3.31 \\
\hline & $\mathrm{O}$ & GLN & 350 & H-acceptor & 3.08 \\
\hline & $\mathrm{O}$ & HIS & 203 & ionic & 2.84 \\
\hline & $\mathrm{O}$ & HIS & 203 & ionic & 3.31 \\
\hline \multirow[t]{8}{*}{23} & $\mathrm{~N}$ & GLU & 206 & H-donor & 2.87 \\
\hline & $\mathrm{N}$ & GLU & 206 & H-donor & 2.87 \\
\hline & $\mathrm{O}$ & HIS & 203 & H-acceptor & 3.08 \\
\hline & $\mathrm{O}$ & HIS & 203 & H-acceptor & 2.99 \\
\hline & $\mathrm{O}$ & HIS & 203 & ionic & 3.08 \\
\hline & $\mathrm{O}$ & HIS & 203 & ionic & 2.99 \\
\hline & $\mathrm{N}$ & GLU & 206 & ionic & 2.87 \\
\hline & $\mathrm{N}$ & GLU & 206 & ionic & 2.87 \\
\hline \multirow[t]{4}{*}{24} & $\mathrm{~N}$ & SER & 348 & H-donor & 2.93 \\
\hline & $\mathrm{O}$ & HIS & 203 & H-acceptor & 2.9 \\
\hline & $\mathrm{O}$ & HIS & 203 & ionic & 3.24 \\
\hline & $\mathrm{O}$ & HIS & 203 & ionic & 2.9 \\
\hline \multirow[t]{11}{*}{25} & $\mathrm{~N}$ & SER & 348 & H-donor & 2.86 \\
\hline & $\mathrm{O}$ & HIS & 203 & H-acceptor & 3.02 \\
\hline & $\mathrm{O}$ & HIS & 203 & H-acceptor & 3.07 \\
\hline & $\mathrm{O}$ & HIS & 203 & ionic & 3.02 \\
\hline & $\mathrm{O}$ & HIS & 203 & ionic & 3.07 \\
\hline & $\mathrm{N}$ & GLU & 206 & H-donor & 3.26 \\
\hline & $\mathrm{O}$ & HIS & 203 & H-acceptor & 2.81 \\
\hline & $\mathrm{O}$ & HIS & 203 & ionic & 2.81 \\
\hline & $\mathrm{N}$ & GLU & 206 & ionic & 3.46 \\
\hline & $\mathrm{N}$ & GLU & 206 & ionic & 3.26 \\
\hline & $\mathrm{N}$ & GLU & 206 & ionic & 3.52 \\
\hline \multirow[t]{5}{*}{27} & $\mathrm{~N}$ & VAL & 187 & H-donor & 3.19 \\
\hline & $\mathrm{O}$ & GLY & 351 & H-acceptor & 3.58 \\
\hline & $\mathrm{O}$ & HIS & 203 & H-acceptor & 2.89 \\
\hline & $\mathrm{O}$ & HIS & 203 & ionic & 2.89 \\
\hline & $\mathrm{O}$ & HIS & 203 & ionic & 3.15 \\
\hline
\end{tabular}

Table S24. Interaction report of each conformer of Sivelestat. Number of conformer, Atom of compound, Amino acid in TMPRSS2, Type of interaction and Distance in angstroms.

\begin{tabular}{c|l|c|c|c|c} 
Conformer & Ligand & \multicolumn{2}{|c|}{ Residues in TMPRSS2 } & Interaction & Distance \\
\hline $\mathbf{1}$ & O & HIS & 203 & H-acceptor & 2.93 \\
\hline $\mathbf{2}$ & N & CYS & 349 & H-donor & 3 \\
\hline & O & HIS & 203 & ionic & 3.26 \\
\hline & 6-ring & GLY & 351 & pi-H & 4.61 \\
\hline $\mathbf{3}$ & O & HIS & 203 & ionic & 3.84 \\
\hline $\mathbf{4}$ & N & CYS & 381 & H-donor & 3.43
\end{tabular}




\begin{tabular}{|c|c|c|c|c|c|}
\hline \multirow{2}{*}{ Conformer } & \multirow{2}{*}{$\begin{array}{l}\text { Ligand } \\
\mathrm{O} \\
\end{array}$} & \multicolumn{2}{|c|}{ Residues in TMPRSS2 } & \multirow{2}{*}{$\begin{array}{c}\text { Interaction } \\
\text { H-acceptor }\end{array}$} & \multirow{2}{*}{$\begin{array}{c}\text { Distance } \\
3.26\end{array}$} \\
\hline & & LYS & 302 & & \\
\hline & $\mathrm{O}$ & LYS & 302 & H-acceptor & 2.94 \\
\hline & $\mathrm{O}$ & LYS & 302 & ionic & 2.94 \\
\hline & 6-ring & GLY & 303 & pi-H & 3.86 \\
\hline \multirow[t]{2}{*}{5} & $\mathrm{O}$ & HIS & 203 & ionic & 3.62 \\
\hline & 6-ring & HIS & 203 & pi-cation & 4.12 \\
\hline \multirow[t]{5}{*}{6} & $\mathrm{O}$ & HIS & 203 & H-acceptor & 2.91 \\
\hline & $\mathrm{O}$ & HIS & 203 & H-acceptor & 3.01 \\
\hline & $\mathrm{O}$ & HIS & 203 & H-acceptor & 3.36 \\
\hline & $\mathrm{O}$ & HIS & 203 & ionic & 3.01 \\
\hline & $\mathrm{O}$ & HIS & 203 & ionic & 3.36 \\
\hline \multirow[t]{7}{*}{7} & $\mathrm{O}$ & CYS & 381 & H-donor & 3.74 \\
\hline & $\mathrm{O}$ & GLY & 351 & H-acceptor & 3.12 \\
\hline & $\mathrm{O}$ & LYS & 383 & H-acceptor & 3.18 \\
\hline & $\mathrm{O}$ & CYS & 381 & H-acceptor & 3.01 \\
\hline & $\mathrm{O}$ & LYS & 383 & H-acceptor & 3.06 \\
\hline & $\mathrm{O}$ & LYS & 383 & ionic & 3.18 \\
\hline & $\mathrm{O}$ & LYS & 383 & ionic & 3.06 \\
\hline \multirow[t]{5}{*}{8} & $\mathrm{O}$ & CYS & 381 & H-donor & 3.89 \\
\hline & $\mathrm{O}$ & LYS & 383 & H-acceptor & 3.16 \\
\hline & $\mathrm{O}$ & CYS & 381 & H-acceptor & 3.35 \\
\hline & $\mathrm{O}$ & LYS & 302 & H-acceptor & 2.86 \\
\hline & $\mathrm{O}$ & LYS & 302 & ionic & 2.86 \\
\hline \multirow[t]{6}{*}{9} & $\mathrm{O}$ & CYS & 381 & H-donor & 3.74 \\
\hline & $\mathrm{O}$ & LYS & 383 & H-acceptor & 3.2 \\
\hline & $\mathrm{O}$ & CYS & 381 & H-acceptor & 3.01 \\
\hline & $\mathrm{O}$ & LYS & 383 & H-acceptor & 3.02 \\
\hline & $\mathrm{O}$ & LYS & 383 & ionic & 3.2 \\
\hline & $\mathrm{O}$ & LYS & 383 & ionic & 3.02 \\
\hline \multirow[t]{3}{*}{10} & $\mathrm{O}$ & HIS & 203 & H-acceptor & 3.04 \\
\hline & $\mathrm{O}$ & HIS & 203 & ionic & 3.97 \\
\hline & $\mathrm{O}$ & HIS & 203 & ionic & 3.3 \\
\hline \multirow[t]{4}{*}{11} & $\mathrm{O}$ & HIS & 203 & H-acceptor & 2.89 \\
\hline & $\mathrm{O}$ & HIS & 203 & H-acceptor & 2.96 \\
\hline & $\mathrm{O}$ & HIS & 203 & ionic & 3.94 \\
\hline & $\mathrm{O}$ & HIS & 203 & ionic & 2.96 \\
\hline \multirow[t]{4}{*}{12} & $\mathrm{O}$ & GLY & 351 & H-acceptor & 2.93 \\
\hline & $\mathrm{O}$ & HIS & 203 & H-acceptor & 2.87 \\
\hline & $\mathrm{O}$ & HIS & 203 & ionic & 3.43 \\
\hline & $\mathrm{O}$ & HIS & 203 & ionic & 2.87 \\
\hline 13 & $\mathrm{O}$ & GLY & 351 & H-acceptor & 3.19 \\
\hline & $\mathrm{O}$ & GLN & 350 & H-acceptor & 3.05 \\
\hline & $\mathrm{O}$ & LYS & 302 & H-acceptor & 2.99 \\
\hline & $\mathrm{O}$ & GLY & 303 & H-acceptor & 3.09 \\
\hline & $\mathrm{O}$ & LYS & 302 & ionic & 2.99 \\
\hline & $\mathrm{O}$ & LYS & 302 & ionic & 3.94 \\
\hline 14 & $\mathrm{O}$ & HIS & 203 & H-acceptor & 3.1 \\
\hline & $\mathrm{O}$ & HIS & 203 & H-acceptor & 2.87 \\
\hline & $\mathrm{O}$ & HIS & 203 & ionic & 2.87 \\
\hline 15 & $\mathrm{O}$ & HIS & 203 & H-acceptor & 3.07 \\
\hline & $\mathrm{O}$ & HIS & 203 & H-acceptor & 3.08 \\
\hline & $\mathrm{O}$ & HIS & 203 & ionic & 2.87 \\
\hline & $\mathrm{O}$ & HIS & 203 & ionic & 3.08 \\
\hline 16 & $\mathrm{O}$ & HIS & 203 & H-acceptor & 2.9 \\
\hline & $\mathrm{O}$ & HIS & 203 & ionic & 2.9 \\
\hline & $\mathrm{O}$ & HIS & 203 & ionic & 3.3 \\
\hline 17 & $\mathrm{O}$ & GLY & 351 & H-acceptor & 2.92 \\
\hline & $\mathrm{O}$ & HIS & 203 & H-acceptor & 2.9 \\
\hline & $\mathrm{O}$ & HIS & 203 & ionic & 2.9 \\
\hline & $\mathrm{O}$ & HIS & 203 & ionic & 3.88 \\
\hline 18 & $\mathrm{O}$ & LYS & 383 & H-acceptor & 3.14 \\
\hline & $\mathrm{O}$ & LYS & 302 & H-acceptor & 2.95 \\
\hline & $\mathrm{O}$ & LYS & 302 & ionic & 3.41 \\
\hline & $\mathrm{O}$ & LYS & 302 & ionic & 2.95 \\
\hline 19 & $\mathrm{O}$ & HIS & 203 & H-acceptor & 2.75 \\
\hline & $\mathrm{O}$ & HIS & 203 & ionic & 3.81 \\
\hline
\end{tabular}




\begin{tabular}{c|l|c|c|c|c}
\multirow{2}{*}{ Conformer } & Ligand & \multicolumn{2}{|c}{ Residues in TMPRSS2 } & Interaction & Distance \\
\hline $\mathbf{2 0}$ & O & GLY & 351 & H-acceptor & 2.91 \\
\hline & O & HIS & 203 & H-acceptor & 2.97 \\
\hline & O & HIS & 203 & ionic & 2.97 \\
\hline & O & HIS & 203 & ionic & 2.99 \\
\hline $\mathbf{2 1}$ & O & HIS & 203 & H-acceptor & 2.93 \\
\hline & O & HIS & 203 & ionic & 2.93 \\
\hline $\mathbf{2 2}$ & N & CYS & 349 & H-donor & 3.3 \\
\hline & O & GLY & 351 & H-acceptor & 2.96 \\
\hline & O & HIS & 203 & H-acceptor & 2.89 \\
\hline & O & HIS & 203 & H-acceptor & 3.44 \\
\hline & O & HIS & 203 & ionic & 2.89 \\
\hline & O & HIS & 203 & ionic & 3.44 \\
\hline $\mathbf{2 3}$ & O-ring & HIS & 203 & pi-cation & 4.37 \\
\hline $\mathbf{2 4}$ & O & HIS & 203 & H-acceptor & 2.95 \\
\hline $\mathbf{2 5}$ & O & HIS & 203 & H-acceptor & 3.21 \\
\hline & O & HIS & 203 & H-acceptor & 3.01 \\
\hline & O & HIS & 203 & ionic & 3.21 \\
\hline & O & HIS & 203 & ionic & 3.01 \\
\hline & O & GLY & 351 & H-acceptor & 3.05 \\
\hline & O & GLN & 350 & H-acceptor & 3.31 \\
\hline & O & LYS & 302 & ionic & 3.26 \\
\hline & O & LYS & 302 & ionic & 3.1
\end{tabular}

Table S25. Interaction report of each conformer of NCGC00385043. Number of conformer, Atom of compound, Amino acid in TMPRSS2, Type of interaction and Distance in angstroms.

\begin{tabular}{|c|c|c|c|c|c|}
\hline \multirow{2}{*}{$\begin{array}{c}\text { Conformer } \\
1\end{array}$} & \multirow{2}{*}{$\begin{array}{l}\text { Ligand } \\
\mathrm{O}\end{array}$} & \multicolumn{2}{|c|}{ Residues in TMPRSS2 } & \multirow{2}{*}{$\frac{\text { Interaction }}{\text { H-donor }}$} & \multirow{2}{*}{$\begin{array}{c}\text { Distance } \\
2.9\end{array}$} \\
\hline & & VAL & 187 & & \\
\hline & $\mathrm{O}$ & CYS & 349 & H-donor & 2.96 \\
\hline & $\mathrm{O}$ & HIS & 203 & H-acceptor & 3.21 \\
\hline 2 & $\mathrm{O}$ & GLY & 351 & H-acceptor & 3.34 \\
\hline \multirow[t]{2}{*}{3} & $\mathrm{O}$ & SER & 348 & H-donor & 2.99 \\
\hline & $\mathrm{O}$ & HIS & 203 & H-acceptor & 3.14 \\
\hline \multirow[t]{2}{*}{4} & $\mathrm{O}$ & VAL & 187 & H-donor & 2.94 \\
\hline & $\mathrm{O}$ & HIS & 203 & H-acceptor & 2.94 \\
\hline \multirow[t]{2}{*}{5} & $\mathrm{O}$ & GLU & 206 & H-donor & 3.16 \\
\hline & $\mathrm{O}$ & HIS & 203 & H-acceptor & 3.38 \\
\hline \multirow[t]{2}{*}{6} & $\mathrm{O}$ & SER & 348 & H-donor & 2.97 \\
\hline & $\mathrm{O}$ & GLY & 378 & H-donor & 2.82 \\
\hline \multirow[t]{2}{*}{7} & $\mathrm{O}$ & CYS & 349 & H-donor & 3.04 \\
\hline & $\mathrm{O}$ & HIS & 203 & H-acceptor & 3.23 \\
\hline \multirow[t]{2}{*}{8} & $\mathrm{O}$ & SER & 348 & H-donor & 3.01 \\
\hline & $\mathrm{O}$ & GLY & 351 & H-acceptor & 3.04 \\
\hline \multirow[t]{3}{*}{9} & $\mathrm{O}$ & GLY & 378 & H-donor & 3.13 \\
\hline & $\mathrm{O}$ & GLY & 378 & H-donor & 2.91 \\
\hline & $\mathrm{O}$ & SER & 348 & H-donor & 2.96 \\
\hline 10 & $\mathrm{O}$ & HIS & 203 & H-acceptor & 3 \\
\hline 11 & $\mathrm{O}$ & SER & 348 & H-donor & 3.05 \\
\hline 12 & $\mathrm{O}$ & SER & 348 & H-donor & 2.98 \\
\hline 13 & $\mathrm{O}$ & CYS & 349 & $\mathrm{H}$-donor & 2.96 \\
\hline 14 & $\mathrm{O}$ & GLY & 351 & H-acceptor & 3.27 \\
\hline 15 & $\mathrm{O}$ & GLY & 351 & H-donor & 3.13 \\
\hline \multirow[t]{3}{*}{16} & $\mathrm{O}$ & SER & 348 & H-donor & 2.8 \\
\hline & $\mathrm{O}$ & HIS & 203 & H-acceptor & 3.03 \\
\hline & $\mathrm{O}$ & GLY & 351 & H-acceptor & 3.18 \\
\hline 17 & $\mathrm{O}$ & HIS & 186 & H-donor & 2.79 \\
\hline \multirow[t]{2}{*}{18} & $\mathrm{O}$ & SER & 348 & H-donor & 2.91 \\
\hline & $\mathrm{O}$ & GLY & 378 & H-donor & 3.04 \\
\hline \multirow[t]{3}{*}{19} & $\mathrm{O}$ & GLY & 351 & H-donor & 3.06 \\
\hline & $\mathrm{O}$ & GLN & 350 & H-donor & 3.13 \\
\hline & $\mathrm{O}$ & CYS & 349 & H-donor & 2.96 \\
\hline \multirow[t]{2}{*}{20} & $\mathrm{O}$ & SER & 379 & H-donor & 3 \\
\hline & $\mathrm{O}$ & HIS & 203 & H-acceptor & 2.95 \\
\hline 21 & $\mathrm{O}$ & ASN & 249 & H-acceptor & 3.04 \\
\hline \multirow[t]{2}{*}{22} & $\mathrm{O}$ & GLY & 351 & H-acceptor & 3.3 \\
\hline & $\mathrm{O}$ & HIS & 203 & H-acceptor & 3.1 \\
\hline
\end{tabular}


Table S26. Interaction report of each conformer of Bromhexine. Number of conformer, Atom of compound,

Amino acid in TMPRSS2, Type of interaction and Distance in angstroms.

\begin{tabular}{c|l|c|c|c|c} 
Conformer & Ligand & \multicolumn{2}{|c}{ Residues in TMPRSS2 } & Interaction & Distance \\
\hline $\mathbf{1}$ & N & SER & 348 & H-donor & 2.98 \\
\hline & 6-ring & GLY & 351 & pi-H & 4.15 \\
\hline $\mathbf{2}$ & N & VAL & 187 & H-donor & 3.42 \\
\hline $\mathbf{3}$ & 6-ring & GLY & 351 & pi-H & 4.05 \\
\hline $\mathbf{4}$ & N & SER & 348 & H-donor & 3.28 \\
\hline & 6-ring & GLY & 351 & pi-H & 4.06 \\
\hline $\mathbf{5}$ & N & HIS & 203 & H-acceptor & 3.04 \\
\hline $\mathbf{6}$ & N & GLY & 378 & H-donor & 3.12 \\
\hline & C & TRP & 377 & H-pi & 4.41 \\
\hline $\mathbf{7}$ & N & CYS & 349 & H-donor & 3.17 \\
\hline $\mathbf{8}$ & N & VAL & 187 & H-donor & 2.92 \\
\hline & 6-ring & GLY & 351 & pi-H & 4.63 \\
\hline $\mathbf{9}$ & N & CYS & 349 & H-donor & 2.99 \\
\hline $\mathbf{1 0}$ & BR & SER & 376 & H-donor & 3.6 \\
\hline $\mathbf{1 1}$ & N & CYS & 349 & H-donor & 2.87 \\
\hline $\mathbf{1 2}$ & 6-ring & HIS & 203 & pi-cation & 4.73 \\
\hline $\mathbf{1 3}$ & BR & VAL & 187 & H-donor & 3.67
\end{tabular}

Table S27. Toxicity - PreADMET | Prediction of ADME/Tox of compounds T1-T10.

T1.-

algae_at 0.0160146

Ames_test mutagen

Carcino_Mouse negative

Carcino_Rat negative

daphnia_at $\quad 0.0368447$

hERG_inhibition medium_risk

medaka_at $\quad 0.00317449$

minnow_at $\quad 0.0141893$

TA100_10RLI positive

TA100_NA negative

TA1535_10RLI negative

TA1535_NA negative

T3.-

algae_at 0.00162258

Ames_test mutagen

Carcino_Mouse negative

Carcino_Rat positive

daphnia_at $\quad 0.00107575$

hERG_inhibition medium_risk

medaka_at $\quad 6.44964 \mathrm{e}-006$

minnow_at $\quad 2.22289 \mathrm{e}-005$

TA100_10RLI negative

TA100_NA negative

TA1535_10RLI negative

TA1535_NA negative

T5.-

algae_at 0.00253114

Ames_test mutagen

Carcino_Mouse negative

Carcino_Rat positive

daphnia_at $\quad 0.000552924$

hERG_inhibition medium_risk

medaka_at $\quad 1.77373 \mathrm{e}-006$

minnow_at $\quad 1.69902 \mathrm{e}-005$

TA100_10RLI positive

TA100_NA negative

TA1535_10RLI positive

TA1535_NA negative

T7.-

algae_at 0.00948831

Ames_test mutagen

Carcino_Mouse negative

Carcino_Rat positive

daphnia_at $\quad 0.010758$

hERG_inhibition medium_risk

medaka_at $\quad 0.000413187$

https://biointerfaceresearch.com/
T2.

algae_at 0.00318792

Ames_test mutagen

Carcino_Mouse negative

Carcino_Rat negative

daphnia_at $\quad 0.00243684$

hERG_inhibition low_risk

medaka_at 2.3298e-005

minnow_at $\quad 0.000274219$

TA100_10RLI positive

TA100_NA negative

TA1535_10RLI negative

TA1535_NA negative

T4.

algae_at 0.013343

Ames_test mutagen

Carcino_Mouse negative

Carcino_Rat positive

daphnia_at $\quad 0.0123293$

hERG_inhibition high_risk

medaka at $\quad 0.000530206$

minnow_at $\quad 0.00376132$

TA100_10RLI positive

TA100_NA positive

TA1535_10RLI positive

TA1535_NA negative

\section{T6.-}

algae_at 0.000292094

Ames_test non-mutagen

Carcino_Mouse positive

Carcino_Rat negative

daphnia_at $\quad 0.000115612$

hERG_inhibition medium risk

medaka_at $\quad 7.43255 \mathrm{e}-008$

minnow_at $\quad 6.61832 \mathrm{e}-007$

TA100_10RLI negative

TA100_NA negative

TA1535_10RLI negative

TA1535_NA negative

T8.

algae_at 0.00163506

Ames_test mutagen

Carcino_Mouse negative

Carcino_Rat negative

daphnia_at $\quad 0.00033623$

hERG_inhibition low_risk

medaka_at $\quad 9.18187 \mathrm{e}-007$ 


\begin{tabular}{ll|ll}
\hline minnow_at & 0.00290509 & minnow_at & 9.75353e-006 \\
TA100_10RLI & positive & TA100_10RLI & negative \\
TA100_NA & positive & TA100_NA & negative \\
TA1535_10RLI & negative & TA1535_10RLI & negative \\
TA1535_NA & negative & TA1535_NA & negative \\
\hline T9.- & & T10.- & \\
algae_at 0.00320645 & algae_at 0.00633173 \\
Ames_test & mutagen & Ames_test & mutagen \\
Carcino_Mouse & negative & Carcino_Mouse & negative \\
Carcino_Rat & positive & Carcino_Rat & positive \\
daphnia_at & 0.00278997 & daphnia_at & 0.00731401 \\
hERG_inhibition & medium_risk & hERG_inhibition & medium_risk \\
medaka_at & 2.82397 e-005 & medaka_at & 0.000199172 \\
minnow_at & 0.000182003 & minnow_at & 0.00157733 \\
TA100_10RLI & negative & TA100_10RLI & positive \\
TA100_NA & negative & TA100_NA & positive \\
TA1535_10RLI & positive & TA1535_10RLI & negative \\
TA1535_NA & negative & TA1535_NA & negative
\end{tabular}

Table S28. ADME - PreADMET | Prediction of ADME/Tox of compounds T1-T10.

T1.-

BBB $\quad 0.0792184$

Buffer_solubility_mg_L $\quad 0.014869$

Caco2 5.08791

CYP_2C19_inhibition

CYP_2C9_inhibition

CYP_2D6_inhibition

CYP_2D6_substrate

CYP_3A4_inhibition

CYP_3A4_substrate

HIA 94.733424

MDCK 48.9391

Pgp_inhibition Non

Plasma_Protein_Binding 87.876841

Pure_water_solubility_mg_L 0.833992

Skin_Permeability -2.29583

SKlogD_value $\quad 4.417320$

SKlogP value $\quad 4.417320$

SKlogS_buffer $\quad-7.509510$

SKlogS_pure $\quad-5.760630$

T3.- $\quad 0.0834699$

Buffer_solubility_mg_L 10.9611**

Caco2 30.3638

CYP_2C19_inhibition

CYP_2C9_inhibition

CYP_2D6_inhibition

CYP_2D6_substrate

CYP_3A4_inhibition

CYP_3A4_substrate

HIA $\quad 94.801241$

MDCK 0.0735266

Pgp_inhibition Inhibitor

Plasma_Protein_Binding 91.538989

Pure_water_solubility_mg_L 0.0137368

Skin_Permeability -3.32269

SKlogD_value $\quad 6.086980$

SKlogP_value $\quad 6.086980$

SKlogS_buffer $\quad-4.697890 * *$

SKlogS_pure $\quad-7.599860$

$\begin{array}{ll}\text { T5.- } & \\ \text { BBB } & 0.140888\end{array}$

Buffer_solubility_mg_L $\quad 2.46049 * *$

Caco2 13.9488

CYP_2C19_inhibition

CYP_2C9_inhibition

CYP 2D6 inhibition

CYP_2D6_substrate

CYP_3A4_inhibition

CYP_3A4_substrate
Non

Inhibitor

Non

Weakly

T2.-

BBB $\quad 0.216377$

Buffer_solubility_mg_L $\quad 0.0018581$

Caco2 35.6274

CYP_2C19_inhibition Non

CYP_2C9_inhibition Inhibitor

CYP_2D6_inhibition Non

CYP_2D6_substrate Non

CYP 3A4 inhibition Non

CYP_3A4_substrate Substrate

HIA 97.710828

MDCK 0.0541355

Pgp_inhibition Inhibitor

Plasma_Protein_Binding 98.183640

Pure_water_solubility_mg_L 0.00112507

Skin_Permeability $-2.28891 *$

SKlogD_value $\quad 5.926930$

SKlogP value $\quad 5.926930$

SKlogS_buffer $\quad-8.463010$

SKlogS_pure $\quad-8.680900$

T4.

BBB $\quad 0.0532063$

Buffer_solubility_mg_L $7.61522 * *$

Caco2 0.701092

CYP_2C19_inhibition Non

CYP_2C9_inhibition Inhibitor

CYP_2D6_inhibition Non

CYP_2D6_substrate Non

CYP_3A4_inhibition Non

CYP_3A4_substrate Weakly

HIA 86.813998

MDCK 0.35926

Pgp_inhibition Inhibitor

Plasma_Protein_Binding 99.658773

Pure_water_solubility_mg_L 0.0631993

Skin_Permeability -3.74129

SKlogD_value $\quad 4.494410$

SKlogP_value $\quad 4.494410$

SKlogS buffer $\quad-4.825510 * *$

SKlogS_pure $\quad-6.906480$

T6.

BBB 0.128735

Buffer_solubility_mg_L $\quad 1.64836 \mathrm{e}-006$

Caco2 23.2206

CYP_2C19_inhibition Non

CYP_2C9_inhibition Inhibitor

CYP_2D6_inhibition Non

CYP_2D6_substrate Non

CYP 3A4 inhibition Inhibitor

CYP_3A4_substrate Substrate 


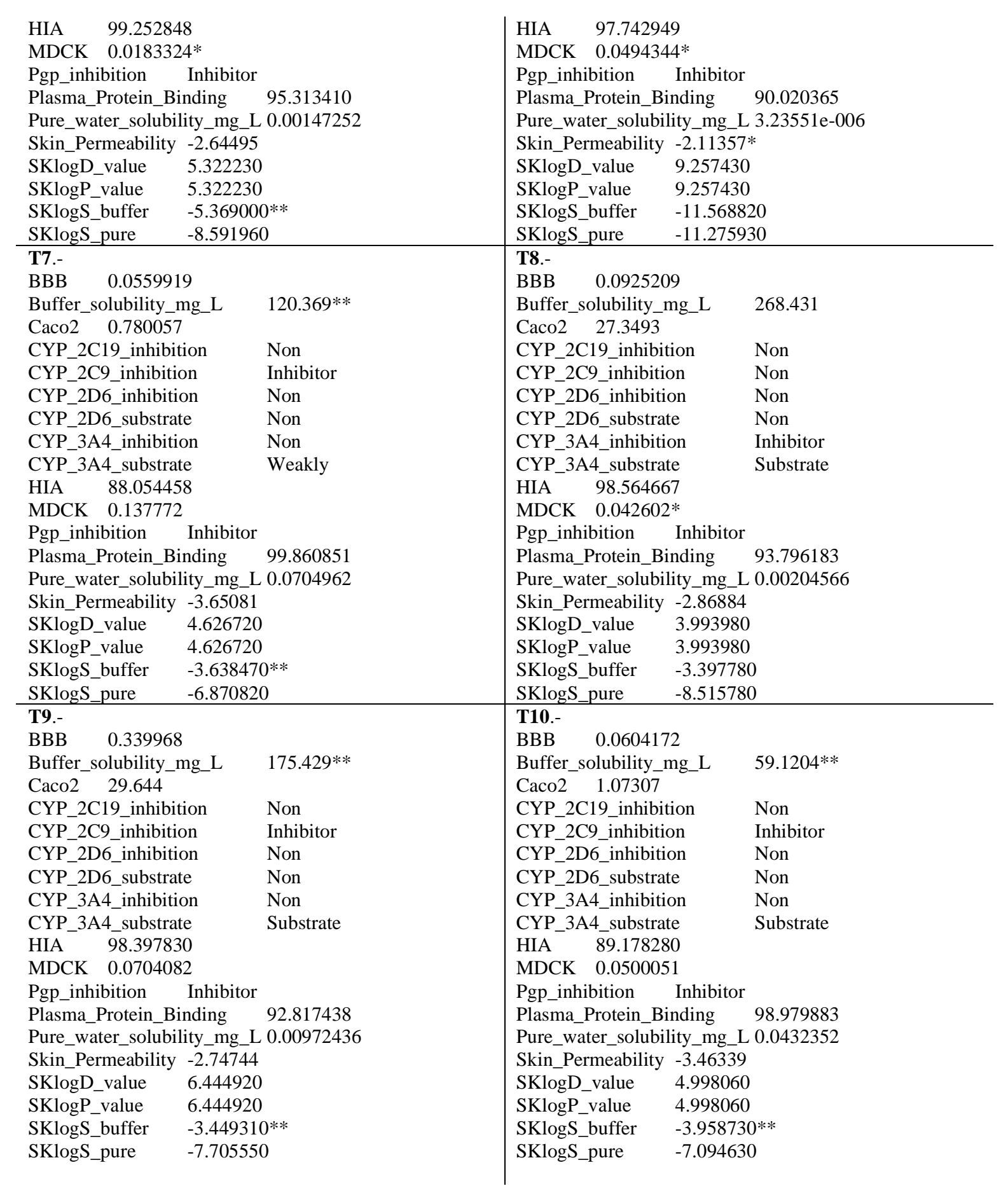

Table S29. Properties predicted by PhysChem - ACD/Labs of compounds T1-T10.

T1.-

Density: $1.1 \pm 0.1 \mathrm{~g} / \mathrm{cm} 3$

Boiling Point:

Vapour Pressure:

Enthalpy of Vaporization:

Flash Point:

Index of Refraction: $\quad 1.561$

Molar Refractivity: $139.8 \pm 0.5 \mathrm{~cm} 3$

\#H bond acceptors: 9

\#H bond donors: 2

\#Freely Rotating Bonds: 14

\#Rule of 5 Violations:

ACD/LogP: $\quad 6.72$

$\mathrm{ACD} / \operatorname{LogD}(\mathrm{pH} 5.5): \quad 4.39$

$\mathrm{ACD} / \mathrm{BCF}(\mathrm{pH} 5.5): \quad 1221.08$

$\mathrm{ACD} / \mathrm{KOC}(\mathrm{pH} 5.5): \quad 5338.00$

$\mathrm{ACD} / \operatorname{LogD}(\mathrm{pH} 7.4): \quad 4.47$
T2.-

Density: $1.3 \pm 0.1 \mathrm{~g} / \mathrm{cm} 3$

Boiling Point:

Vapour Pressure:

Enthalpy of Vaporization:

Flash Point:

Index of Refraction: $\quad 1.669$

Molar Refractivity: $151.6 \pm 0.5 \mathrm{~cm} 3$

\#H bond acceptors: 9

\#H bond donors: 1

\#Freely Rotating Bonds: 9

\#Rule of 5 Violations: 2

ACD/LogP: $\quad 6.41$

$\mathrm{ACD} / \operatorname{LogD}(\mathrm{pH} 5.5): \quad 4.76$

ACD/BCF (pH 5.5): $\quad 2438.11$

$\mathrm{ACD} / \mathrm{KOC}(\mathrm{pH} 5.5): \quad 9247.98$

$\mathrm{ACD} / \log \mathrm{D}(\mathrm{pH} 7.4): \quad 4.76$

https://biointerfaceresearch.com/ 


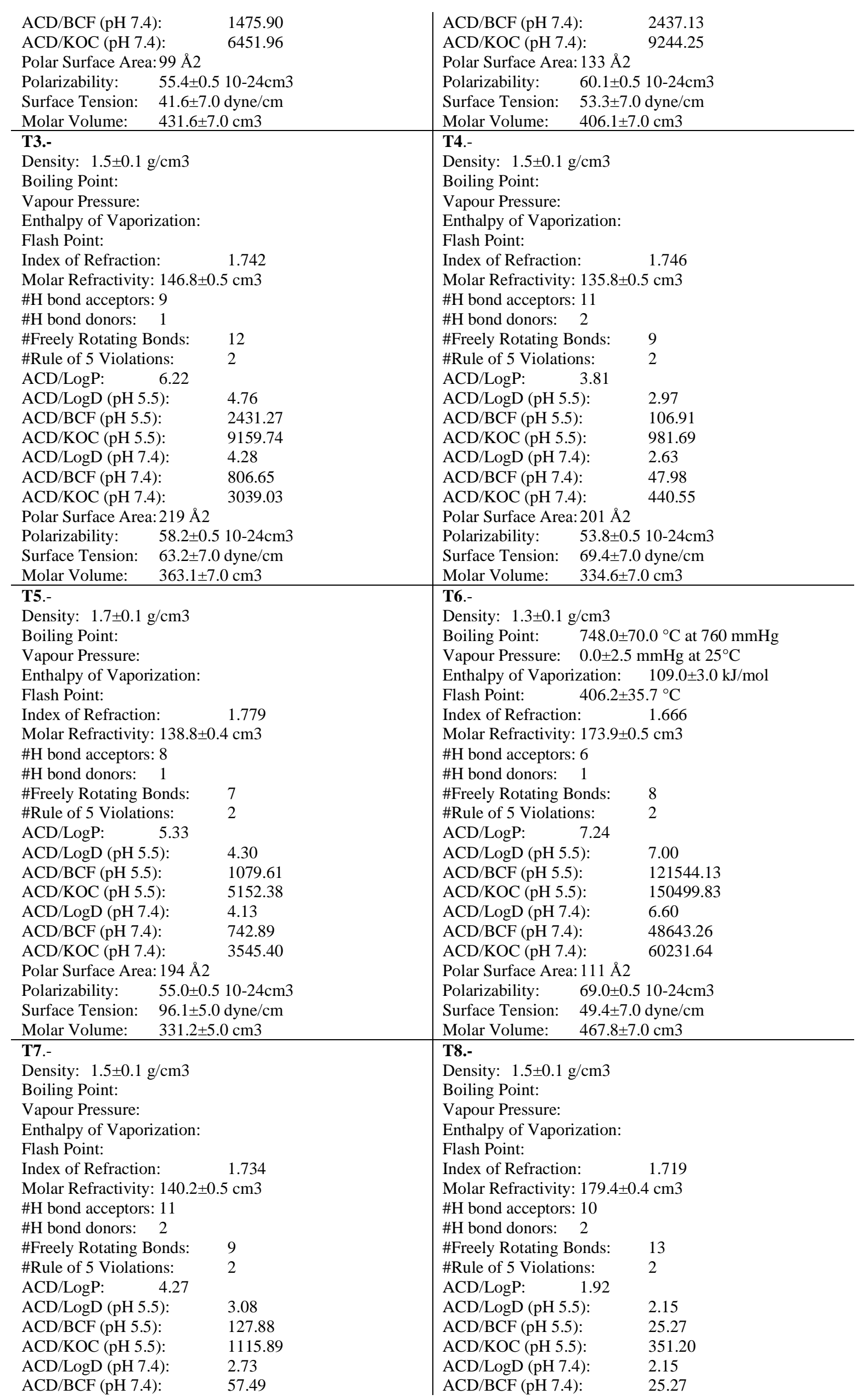




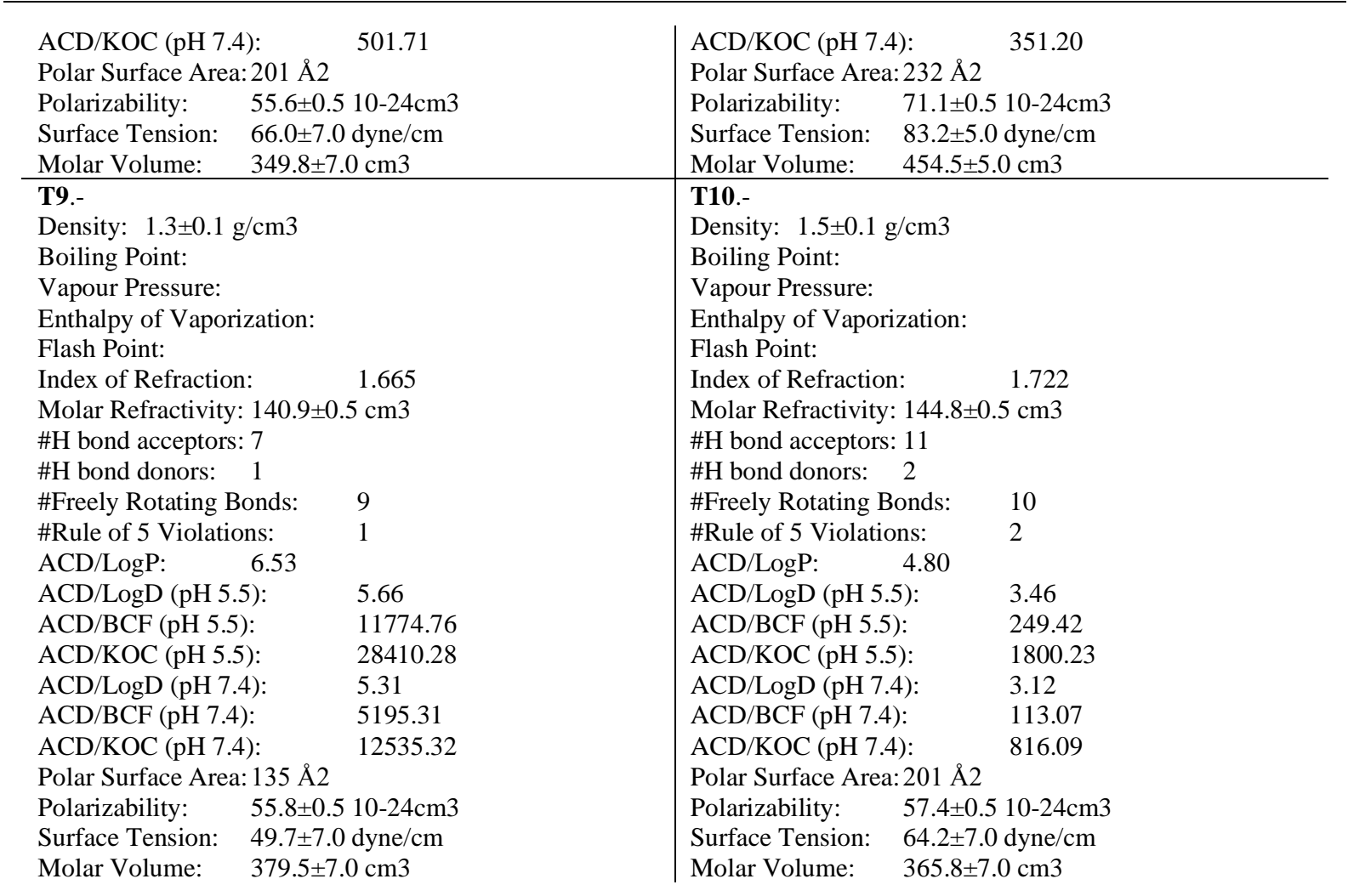

